NBER WORKING PAPER SERIES

\title{
IS THERE A RISK-RETURN TRADEOFF IN THE CORPORATE BOND MARKET? TIME-SERIES AND CROSS-SECTIONAL EVIDENCE
}

\author{
Jennie Bai \\ Turan G. Bali \\ Quan Wen \\ Working Paper 25995 \\ http://www.nber.org/papers/w25995 \\ NATIONAL BUREAU OF ECONOMIC RESEARCH \\ 1050 Massachusetts Avenue \\ Cambridge, MA 02138 \\ June 2019
}

We thank Andreas Barth, Marc Crummenerl, Kris Jacobs, Yigitcan Karabulut, Francesco Sangiorgi, Christian Schlag, Grigory Vilkov, and seminar participants at Bloomberg, Frankfurt School of Finance and Management, Goethe University, University of Houston, and 2019 Qgroup annual conference for their helpful comments and suggestions. We also thank Kenneth French, Lubos Pastor, and Robert Stambaugh for making a large amount of historical data publicly available. All errors remain our responsibility. The views expressed herein are those of the authors and do not necessarily reflect the views of the National Bureau of Economic Research.

NBER working papers are circulated for discussion and comment purposes. They have not been peer-reviewed or been subject to the review by the NBER Board of Directors that accompanies official NBER publications.

(C) 2019 by Jennie Bai, Turan G. Bali, and Quan Wen. All rights reserved. Short sections of text, not to exceed two paragraphs, may be quoted without explicit permission provided that full credit, including $(\subset$ notice, is given to the source. 
Is There a Risk-Return Tradeoff in the Corporate Bond Market? Time-Series and Cross-Sectional Evidence

Jennie Bai, Turan G. Bali, and Quan Wen

NBER Working Paper No. 25995

June 2019, Revised May 2020

JEL No. C13,G10,G11,G12

\author{
ABSTRACT \\ (equity) market. \\ Jennie Bai \\ McDonough School of Business \\ Georgetown University \\ 3700 O Street, NW \\ Washington, DC 20057 \\ and NBER \\ jennie.bai@georgetown.edu \\ Turan G. Bali \\ McDonough School of Business \\ Georgetown University \\ Between 37th and O Streets \\ Washington, D.C. 20057 \\ turan.bali@georgetown.edu \\ Quan Wen \\ Georgetown University \\ Washington, DC 20057 \\ quan.wen@georgetown.edu
}

We provide time-series and cross-sectional evidence on the significance of a risk-return tradeoff in the corporate bond market. We find a significantly positive intertemporal relation between expected return and risk in the bond market and the time-series predictability is driven by aggregate systematic risk instead of aggregate idiosyncratic risk. We also propose a new measure of systematic risk for corporate bonds and find a positive link between systematic risk and the cross-section of future bond returns. We provide an explanation for the significance of systematic (idiosyncratic) risk based on different investor preferences and informational frictions in the bond 


\section{Introduction}

Most asset pricing theories postulate a positive intertemporal relation between expected return and risk of market portfolios (Merton, 1973). Empirically, this relation has been studied primarily in the equity market. The literature, however, has not yet reached to an agreement on the existence of a positive risk-return tradeoff for stock market indices; indeed, many studies cannot even identify a robust and significant time-series relation. ${ }^{1}$

While earlier studies focus on equities, debt financing forms a significant portion in the capital structure of U.S. corporations (Graham, Leary, and Roberts, 2015), underscoring the need to study the risk-return tradeoff in the corporate bond market. Since the Great Recession of 2007-2009, the corporate bond market has increased substantially with respect to trading volume and the market size. ${ }^{2}$ Institutional investors in particular make an extensive use of bonds in constructing their portfolios, which elevates the role of bonds in investors' portfolios more than any time in the past. Motivated by these observations, this paper studies the risk-return tradeoff in the corporate bond market.

Does the risk-return relation for equities or its lack thereof extend to corporate bonds? This is an open question given the significant difference in institutional and informational frictions across equities and bonds. Using a big dataset of 1.3 million bond return observations from January 1995 to June 2019, we provide the first comprehensive study on the risk-return

\footnotetext{
${ }^{1}$ French, Schwert, and Stambaugh (1987) find that the risk-return coefficient is not significantly different from zero when they use past daily returns to estimate the monthly conditional variance. Follow-up studies by Campbell and Hentchel (1992), Glosten, Jagannathan, and Runkle (1993), Harrison and Zhang (1999), and Bollerslev and Zhou (2006) rely on the GARCH-in-mean and realized volatility models that provide no evidence of a robust, significant link between risk and return on the equity market portfolio. Several studies even find that the intertemporal relation between risk and return is negative (e.g., Campbell, 1987; Nelson, 1991; Glosten et al., 1993; Whitelaw, 1994; Harvey, 2001; and Brandt and Kang, 2004). Some studies do provide evidence supporting a positive and significant link between expected return and risk in the equity market (e.g., Bollerslev, Engle, and Wooldridge, 1988; Ghysels, Santa-Clara, and Valkanov, 2005; Guo and Whitelaw, 2006; Bali, 2008; and Bali and Engle, 2010).

${ }^{2}$ Corporate bonds constitute one of the largest components of the U.S. bond market, which is considered the largest security market in the world. According to the Federal Reserve database, the total market value of outstanding corporate bonds in the United States was about $\$ 1.74$ trillion in 1990 and it increased monotonically to $\$ 14.02$ trillion by the end of 2019 . This implies an annual growth rate of $7.6 \%$ from 1990 to 2019 . The corporate bond market is active as well. Over the past 16 years, daily trading volume has been in the range of $\$ 12.6$ and $\$ 24.5$ billion, with an average of $\$ 17.6$ billion (source: www.sifma.org).
} 
tradeoff in the corporate bond market, both in time series and in the cross section. Overall, we ascertain a robust, significant, and positive intertemporal relation between expected return and risk in aggregate bond market portfolios, and also a consistent positive risk-return relation in the cross section of individual bonds. Our findings in the bond market are in line with asset pricing theories, but are foiled against the evidence in the equity market. We delineate reconciling explanations later in this section and more details in Section 5. The basic idea is that the investor clientele plays an important role in the contrasting risk-return relations in the bond versus equity markets.

We start the analysis with the intertemporal relation between the conditional mean and the conditional variance of aggregate bond market returns. We find that the bond market risk proxied by its lagged (or conditional) variance predicts future bond market returns. Moreover, we show that the time-series predictability is driven solely by aggregate systematic risk instead of aggregate idiosyncratic risk. The results are robust under three different weighting schemes in aggregating the bond-level risk measures, namely, the equal-weighted, value-weighted, and rating-weighted average. The results are also robust to controlling for a number of variables proxying for business cycle fluctuations.

To appraise the economic significance of the time-series predictability, we simulate the returns of a trading strategy based on the out-of-sample one-month-ahead forecasts of the bond market using its realized variance. ${ }^{3}$ In this market-timing strategy, we obtain both a higher mean return and a lower standard deviation compared to the strategy using the forecasts from existing corporate bond market factors. We find that a risk-averse investor is willing to pay an annualized fee of 3.6 5.0\% to invest in the strategy that forecasts the bond market return based on the market variance.

After thoroughly investigating the time-series risk-return relation at the market level, we propose new measures of bond-level systematic and idiosyncratic risk and examine the

\footnotetext{
${ }^{3}$ For each month $t$, the strategy invests $100 \%$ in the bond market index if the predicted excess return of bonds over the risk-free rate is greater than zero; otherwise it invests $100 \%$ in Treasury bills. At time $t+1$, the return of the portfolio is realized, a new regression is estimated, a return forecast computed, and new portfolio weights determined. In this way, we obtain a monthly time series of returns to the trading strategy.
} 
cross-sectional predictability on individual corporate bonds. Consistent with the time-series predictability results at the market level, we find a significantly positive link between systematic risk and the cross-section of future bond returns, whereas the cross-sectional relation between idiosyncratic risk and future bond returns is economically and statistically insignificant. Overall, the results indicate that institutional investors dominating the bond market hold well-diversified portfolios with a negligible exposure to bond-specific risk.

One central prediction in classical asset pricing theory is that the cross-sectional differences in expected returns on securities are explained solely by their systematic risk under the assumptions that markets are complete and frictionless and investors are well-diversified (Merton, 1987). If markets are incomplete or investors face frictions and hold poorly diversified portfolios, then expected returns should be positively associated with idiosyncratic volatility (Hirshleifer, 1988). Empirically, the most widely-cited study on idiosyncratic risk, Ang, Hodrick, Xing, and Zhang (2006), demonstrates a negative cross-sectional relation between idiosyncratic volatility and future equity returns. This result is highly inconsistent with theoretical predictions and thus considered a puzzle. Several subsequent papers have proposed explanations for the idiosyncratic volatility (IVOL) puzzle in the equity market (see Hou and Loh (2016) for a summary).

In this paper, we revisit the IVOL puzzle in the corporate bond market by proposing new measures of idiosyncratic and systematic risk of corporate bonds. According to a recent work by Bai, Bali, and Wen (2019, hereafter BBW), it is crucial to rely on the prominent features of corporate bonds when constructing bond-implied risk factors, in particular because the bond market is dominated by institutional investors and such clientele requires compensation for risks different from those in the equity market. BBW introduce novel risk factors based on downside risk, credit risk, and liquidity risk of corporate bonds and show that these bond factors have significant risk premia and outperform all other models in the literature.

After assembling a comprehensive dataset of corporate bond transactions from 1995 to 2019, we conduct nonparametric portfolio analyses. For each bond and each month in our 
sample, we regress the monthly excess returns of corporate bonds on BBW's risk factors. Idiosyncratic risk of an individual bond is measured by the residual variance of bond excess returns from the monthly time-series regressions. Accordingly, systematic risk of an individual bond is defined as the difference between the total and the residual variance, which is a function of the variance of risk factors, the covariance of them, and the bond exposures to risk factors.

Consistent with the theoretical predictions, we show that there does not exist an IVOL puzzle in the corporate bond market; instead, future bond returns are explained by their systematic risk. When sorting corporate bonds into quintile portfolios based on their systematic risk, we find that bonds in the highest systematic risk quintile generate $7.32 \% \sim 10.20 \%$ per annum higher return than bonds in the lowest systematic risk quintile, with the premium stemming from the superior performance of bonds with high systematic risk (long leg of the arbitrage portfolio). Such results remain robust after controlling for various bond characteristics. In contrast, idiosyncratic risk has no significant explanatory power. When comparing the relative performance of systematic and idiosyncratic risk in terms of their ability to predict the cross-sectional differences in future bond returns, we find that idiosyncratic risk becomes even weaker, both economically and statistically, after controlling for systematic risk, whereas systematic risk remains a significant determinant of the cross-sectional dispersion in bond returns after controlling for idiosyncratic risk.

Since corporate bonds and equities issued by the same firm are contingent claims on the on the same cash flows (Merton, 1974), it may be surprising to see the contradictory findings on the relation between expected return and risk in the equity versus bond markets. There are at least two major reasons why the findings in the equity market do not directly apply to the bond market. First, Merton (1974) makes a number of assumptions in a perfect financial market to obtain the no-arbitrage relation: $(i)$ all investors are symmetrically informed; (ii) there are no transaction costs, no taxes, and no restrictions on short selling; and (iii) lending rates equal borrowing rates. However, these assumptions do not generally hold in 
practice. For example, equities and bonds attract different clienteles (Auh and Bai, 2020). Corporate bonds are primarily held by sophisticated institutional investors, whereas naive retail investors form a material part of the clientele for equities. ${ }^{4}$ It is reasonable to argue that the risk appetites and investment objectives of institutional and retail investors differ as well, suggesting heterogeneity in information sets and preferences across the two markets. Further, shorting costs as well as liquidity levels are markedly different across the two asset classes (Edwards, Harris, and Piwowar, 2007), suggesting arbitrage frictions. Finally, equities and bonds are held by investors who are subject to different regulatory, capital, and funding liquidity constraints (Bali, Subrahmanyam, and Wen, 2020).

Second, equity and bond returns are not perfectly correlated (Cao, Goyal, Xiao, and Zhan, 2020) as they are driven by different risk factors (Bai, Bali, and Wen, 2019). The correlation between equities and non-investment-grade bonds tends to be higher than that between equities and investment-grade bonds. Confirming this observation, our sample shows that the correlation between the monthly returns of non-investment-grade bonds (investmentgrade bonds) and equities is $0.38(0.22) .{ }^{5}$ It is also important to note that an equity is a long position in call option on the firm's asset, while a bond is a short position in put option on the firm's asset. Thus, equity and bond prices may react differently to changes in the firm's asset volatility. As such, the direction and significance of the time-series and cross-sectional relations between expected return and risk in the equity and bond markets may differ.

To reconcile the conflicting findings on the risk-return tradeoff for equities and bonds, we explore a potential explanation based on investor preferences and clienteles. According to the Flow of Funds report released by the Federal Reserve Board, corporate bonds are primarily held by institutional investors, in particular long-term investors such as insurance companies, whereas equities are mainly held by retail investors. As of 2019, retail investors

\footnotetext{
${ }^{4}$ According to flow of fund data from 1986 to 2019 , approximately $78 \%$ of corporate bonds were held by institutional investors, including insurance companies, mutual funds, and pension funds. The participation rate of retail investors in the corporate bond market is very low.

${ }^{5}$ The generally low correlation between equity and bond returns is also consistent with Kapadia and $\mathrm{Pu}$ (2012), Chordia et al. (2017), and Bali et al. (2020).
} 
own about $6 \%$ in the corporate bond market versus $37 \%$ in the equity market. Clearly, two groups of investors; retail vs. institutional, have distinct risk appetites, preferences, and investment objectives. Thus, investor clientele can be a plausible cause of the different riskreturn relations in the bond and equity markets. Indeed, we find that in the equity market, the IVOL puzzle is only pronounced for stocks predominantly held by retail investors but absent for those largely held by institutional investors. In the corporate bond market, we find that the idiosyncratic volatility effect is uniformly weak, no matter if the institutional ownership is high or low. Hence, the investor clientele is likely an explanation for the significance of systematic risk (idiosyncratic risk) in the bond (equity) market.

\section{Data}

\subsection{Corporate bond returns}

We compile corporate bond pricing data from the National Association of Insurance Commissioners database (NAIC) and the enhanced version of the Trade Reporting and Compliance Engine (TRACE) for the sample period from January 1994 to June 2019, with the TRACE data starting from July 2002. We then merge corporate bond pricing data with the Mergent fixed income securities database to obtain bond characteristics such as offering amount, offering date, maturity date, coupon rate, coupon type, interest payment frequency, bond type, bond rating, bond option features, and issuer information.

For bond pricing data, we adopt the filtering criteria proposed by Bai, Bali, and Wen (2019). Specifically, we remove bonds that (i) are not listed or traded in the U.S. public market, or not issued by U.S. companies; (ii) are structured notes, mortgage-backed, assetbacked, agency-backed, or equity-linked; (iii) are convertible; (iv) trade under $\$ 5$ or above $\$ 1,000$; (v) have floating coupon rates; and (vi) have less than one year to maturity. For intraday data, we also eliminate bond transactions that (vii) are labeled as when-issued, locked-in, or have special sales conditions; (viii) are canceled, and (ix) have a trading volume 
smaller than $\$ 10,000$. From the original intraday transaction records, we first calculate the daily clean price as the trading volume-weighted average of intraday prices to minimize the effect of bid-ask spreads in prices, following Bessembinder et al. (2009).

The corporate bond return in month $t$ is computed as

$$
r_{i, t}=\frac{P_{i, t}+A I_{i, t}+\text { Coupon }_{i, t}}{P_{i, t-1}+A I_{i, t-1}}-1,
$$

where $P_{i, t}$ is the end-of-month transaction price, $A I_{i, t}$ is accrued interest on the same day of bond prices, and Coupon $_{i, t}$ is the coupon payment in month $t$, if any. The end-of-month price refers to the last daily observation if there are multiple trading records in the last ten days of a given month. We denote $R_{i, t}$ as bond $i$ 's excess return, $R_{i, t}=r_{i, t}-r_{f, t}$, where $r_{f, t}$ is the risk-free rate proxied by the one-month Treasury bill rate.

After applying the aforementioned data filtering criteria, our sample includes 23,859 bonds issued by 4,485 unique firms, for a total of 1,318,058 bond-month return observations covering the sample period from January 1995 to June 2019. Bonds in our sample have an average monthly return of $0.77 \%$, an average rating of 8 (i.e., $\mathrm{BBB}+$ ), an average issue size of 450 million dollars, and an average time-to-maturity of 10.13 years. The sample consists of $75 \%$ investment-grade bonds and $25 \%$ high-yield bonds. ${ }^{6}$

\subsection{The corporate bond market index}

To capture the U.S. corporate bond market returns, we generate an index of the bond market using the value-weighted average monthly returns of all bonds in our sample for the period January 1995 - June 2019. As a robustness check, we also use the Merrill Lynch U.S. Corporate Index which is comprised of U.S. dollar denominated investment grade corporate

\footnotetext{
${ }^{6}$ We collect bond-level rating information from Mergent FISD historical ratings and assign a number to facilitate the analysis. Specifically, 1 refers to a AAA rating, 2 refers to AA+, ..., and 21 refers to CCC. Investment-grade bonds have ratings from 1 (AAA) to 10 (BBB-). Non-investment-grade bonds have ratings above 10. A larger number indicates higher credit risk or lower credit quality. We determine a bond's rating as the average of ratings provided by S\&P and Moody's when both are available, or as the rating provided by one of the two rating agencies when only one rating is available.
} 
bonds publicly issued in the U.S. domestic market with at least one year to maturity. The average (median) excess return on the value-weighted bond market index is $0.33 \%(0.31 \%)$ per month with a standard deviation of $1.43 \%$. Similarly, the average (median) excess return

on the Merrill Lynch bond index is $0.32 \%$ (0.38\%) per month with a standard deviation of 1.48\%. As expected, the correlation between the two bond market indexes is economically and statistically significant: $88 \%$ with a $t$-statistic of 14.41 .

\subsection{Corporate bond and equity holdings}

To investigate the clientele effect in the equity and bond markets, we also collect the data on asset holdings. For equity holdings, we use the Thomson Reuters' institutional holdings (13F) database that covers all investment companies including banks, insurance companies, mutual funds, pension funds, university endowments, and other types of professional investment advisors for the sample period of 1980-2019. For bond holdings, we use the Thomson Reuters eMaxx data that covers investment companies including insurance companies, mutual funds, and pension funds for the sample period of 2001-2017 (the earliest bond holding data starts from 2001). For each asset, equity or corporate bond, we aggregate the shares held by all institutional investors provided in the data and label it as institutional ownership, INST.

\section{The Intertemporal Relation Between Expected Return and Risk}

The Merton (1973) intertemporal capital asset pricing model (ICAPM) shows that the conditional expected excess return on aggregate market is a linear function of its conditional variance plus a hedging demand component that captures investors' motive to hedge unfavorable shifts in future investment opportunities. Merton (1980) indicates that the intertemporal hedging demand component becomes negligible under certain conditions, and the conditional expected excess return on the market, $E_{t}\left(R_{m, t+1}\right)$, should vary positively with the market's 
conditional variance, $E_{t}\left(\sigma_{m, t+1}^{2}\right)$ :

$$
E_{t}\left(R_{m, t+1}\right)=\gamma E_{t}\left(\sigma_{m, t+1}^{2}\right)
$$

where $\gamma$ is the coefficient of relative risk aversion of the representative agent and according to the model, $\gamma$ should be positive. Equation (2) establishes the dynamic relation that investors require a larger risk premium at times when the market is riskier.

Despite the theoretical appeal of the ICAPM, the trade-off has been hard to find in the data. Previous estimates of the relation between risk and return in the equity market often have been insignificant and sometimes even negative. In this section, we first investigate the intertemporal risk-return relation in the corporate bond market, then compare the findings to those in the equity market.

\subsection{The intertemporal risk-return tradeoff in the bond market}

Following French, Schwert, and Stambaugh (1987), we examine the intertemporal relation between expected return and risk of bond market returns based on the following time-series predictive regressions:

$$
\begin{aligned}
& R_{m, t+1}=\alpha+\beta \cdot \sigma_{m, t}^{2}+\epsilon_{m, t+1} \\
& \sigma_{m, t}^{2}=\frac{1}{n-1} \sum_{t=1}^{n}\left(R_{m, t}-\bar{R}_{m}\right)^{2}
\end{aligned}
$$

where $R_{m, t+1}$ is the monthly excess return of the bond market in month $t+1 ; \sigma_{m, t}^{2}$ is the realized variance of the bond market in month $t$, as a proxy for the expected conditional variance of bond market excess returns, $\sigma_{m, t}^{2} \approx E_{t}\left(\sigma_{m, t+1}^{2}\right)$. According to the ICAPM, $\alpha$ should be zero and $\beta$ should be positive. In Eq. (4), $\bar{R}_{m}=\frac{\sum_{t=1}^{n} R_{m, t}}{n}$ is the sample average of market excess returns over the past 36 months $(n=36)$, and $\sigma_{m, t}^{2}$ is the sample variance of monthly excess returns over the past 36 months. 
Table 1 presents the results from the monthly predictive regressions with the valueweighted corporate bond market index $\left(\mathrm{VW}^{\text {bond }}\right)$ and the Merrill Lynch bond index (MRL $\left.{ }^{\text {bond }}\right)$. Consistent with the theoretical predictions, the estimated slope coefficient on the lagged realized variance $(\beta)$ is positive and statistically significant: $21.75(t$-stat. $=2.55)$ for $\mathrm{VW}^{\text {bond }}$ and $17.53(t$-stat. $=2.22)$ for $\mathrm{MRL}^{\text {bond }}{ }^{7}$ The estimate of the intercept term $(\alpha)$ is insignificant: $-0.10(t$-stat. $=-0.53)$ for $\mathrm{VW}^{\text {bond }}$ and $-0.08(t$-stat. $=-0.38)$ for MRL ${ }^{\text {bond }}$. The adjusted $R^{2}$ values, $6.49 \%$ for $\mathrm{VW}^{\text {bond }}$ and $3.50 \%$ for $\mathrm{MRL}^{\text {bond }}$, are very high, compared to the earlier studies on the equity market. Overall, these results provide strong evidence of a significant and positive intertemporal relation between expected return and risk in the corporate bond market.

The estimated slope coefficients, 21.75 for $\mathrm{VW}^{\text {bond }}$ and 17.53 for $\mathrm{MRL}^{\text {bond }}$, may appear notably large to the asset pricing audience as they are familiar with much smaller estimates of the risk aversion coefficient in the equity market. To provide an insight on the magnitude, we calculate the unconditional mean $\left(\mu_{m}\right)$ and the unconditional variance $\left(\sigma_{m}^{2}\right)$ of excess returns on $\mathrm{VW}^{\text {bond }}$ and $\mathrm{MRL}^{\text {bond }}$ as well as the ratio of the sample mean to variance $\left(\mu_{m} / \sigma_{m}^{2}\right)$. For the sample period of January 1997 - June 2019, the unconditional mean, variance, and the ratio are $\mu_{m}=0.33 \%, \sigma_{m}^{2}=0.021 \%$, and $\mu_{m} / \sigma_{m}^{2}=16.09$ for $\mathrm{VW}^{\text {bond }}$ and $\mu_{m}=0.32 \%, \sigma_{m}^{2}=0.022 \%$, and $\mu_{m} / \sigma_{m}^{2}=14.76$ for MRL ${ }^{\text {bond }}$. As shown in Eq. (2), these large ratios, 16.09 and 14.76, are proxies of the relative risk aversion coefficient $(\gamma)$, assuming that the hedging demand component is negligible. The fact that the estimated slope coefficients, 21.75 for $\mathrm{VW}^{\text {bond }}$ and 17.53 for $\mathrm{MRL}^{\text {bond }}$ as reported in Table 1, are close to their unconditional counterparts (16.09 and 14.76, respectively) suggests that the lagged realized variance, $\sigma_{m, t}^{2}$, is a good proxy for $E_{t}\left(\sigma_{m, t+1}^{2}\right)$ in the bond market.

To provide a comparison, we also calculate the same statistics for aggregate stock market portfolio, proxied by the value-weighted average returns of all stocks trading in NYSE, AMEX, and NASDAQ (i.e., the CRSP index). For the same sample period, the unconditional mean,

\footnotetext{
${ }^{7}$ The $t$-statistics are estimated using the Newey and West (1987) adjustment with six lags to account for autocorrelation and heteroscedasticity in monthly bond returns.
} 
variance, and the ratio for the equity market are $\mu_{m}=0.59 \%, \sigma_{m}^{2}=0.20 \%$, and $\mu_{m} / \sigma_{m}^{2}=2.91$. Thus, consistent with earlier studies, the unconditional estimate of relatively risk aversion coefficient is much lower at 2.91 for the equity market.

\subsubsection{Robustness check: Controlling for the hedging demand}

As shown by Merton (1973), and subsequently pointed out by Campbell (1987), Guo and Whitelaw (2006), and Bali and Engle (2010), Eq. (2) omits the hedging demand component that captures investors' motive to hedge for future investment opportunities. Thus, we include financial and macroeconomic variables to capture the state variables that determine the investment opportunity set: ${ }^{8}$

$$
R_{m, t+1}=\alpha+\beta \cdot \sigma_{m, t}^{2}+\lambda \cdot X_{t}+\epsilon_{m, t+1}
$$

where $X_{t}$ denotes a vector of the one-month lagged financial and macroeconomic variables proxying for business cycle fluctuations. Following Goyal and Welch (2008), we control for variables related to macro fundamentals including the log earnings-to-price ratio (EP), the log dividend-to-price ratio (DP), the book-to-market ratio (BM), the difference between long-term return on government bonds and the one-month Treasury-bill (TERM), and the difference between the return on a market portfolio of long-term corporate bonds and the long-term government bond return (DEF).

Panel B in Table 1 shows that the intertemporal risk-return relation remains strong after accounting for the hedging demand. It is important to note that the slope coefficients on $\sigma_{m, t}^{2}$ reduce from 21.75 to 10.62 for $\mathrm{VW}^{\text {bond }}$ and from 17.53 to 11.18 for $\mathrm{MRL}^{\text {bond }}$, although both estimates remain highly significant. These results indicate that the corporate bond investors demand extra compensation in the form of higher expected return for bearing the unfavorable shifts in the investment opportunity set due to heightened distress risk, default risk, and/or

\footnotetext{
${ }^{8}$ See, e.g., Chen, Roll, and Ross (1986), Keim and Stambaugh (1986), Campbell and Shiller (1988), Fama and French (1988, 1989), Fama (1990), Campbell (1991), and Ferson and Harvey (1991).
} 
interest rate risk proxied by the control variables such as value-to-price ratios, default spread, and term spread. Thus, accounting for the changes in these state variables leads to a decline in the slope coefficients on the lagged realized variance.

\subsubsection{Robustness check: GARCH-in-Mean model}

We also estimate the risk-return tradeoff using an alternative approach proposed by Engle, Lilien, and Robins (1987), the generalized autoregressive conditional heteroskedasticity (GARCH)-in-Mean model:

$$
\begin{gathered}
R_{m, t+1}=\alpha+\beta \cdot \sigma_{m, t+1 \mid t}^{2}+\epsilon_{m, t+1} \\
E_{t}\left(\epsilon_{m, t+1}^{2} \mid \Omega_{t}\right)=\sigma_{m, t+1 \mid t}^{2}=\theta_{0}+\theta_{1} \epsilon_{m, t}^{2}+\theta_{2} \sigma_{m, t}^{2}
\end{gathered}
$$

where $R_{m, t+1}$ is the monthly excess return of the bond market in month $t+1$ and $\sigma_{m, t+1 \mid t}^{2}$ is the time- $t$ expected conditional variance of bond market excess returns. In Eq. (7), $\Omega_{t}$ denotes the information set available at time $t$ and the one-month-ahead conditional variance of bond market returns is a function of current unexpected news $\left(\epsilon_{m, t}^{2}\right)$ and current variance $\left(\sigma_{m, t}^{2}\right)$.

Panel A of Table A.1 in the online appendix shows that for the period January 1997 - June 2019, the estimated slope coefficient on the conditional variance of the bond market is positive and significant: $\beta=20.13$ ( $t$-stat. $=2.62$ ), whereas the estimate for the equity market is positive but insignificant: $\beta=1.24$ ( $t$-stat. $=0.47) .{ }^{9}$ We also replicate the GARCH-in-Mean analysis for the equity market using the longest sample period available at CRSP (July 1926-June 2019) and the estimate is similar: $\beta=1.13(t$-stat. $=1.50)$.

Note that the GARCH model of Bollerslev (1986) in Eq. (7) is defined as a function of the squared information shocks to the bond market (or squared unexpected news in the bond market). Since positive and negative shocks of the same magnitude produce the same

\footnotetext{
${ }^{9}$ It is important to note that for the bond market, the magnitude of the risk aversion coefficient obtained from the GARCH-in-Mean model, 20.13, is very close to the coefficient obtained from the realized variance model, 21.75, reported in Table 1.
} 
amount of volatility, the symmetric GARCH model in Eq. (7) cannot cope with the skewness of bond market returns. Hence, one may think that the risk-return coefficients from the symmetric GARCH-in-Mean model are biased for skewed bond return series. To alleviate this potential concern, we use the asymmetric GARCH model of Glosten et al. (1993), known as the Threshold GARCH (or GJRGARCH) model:

$$
\begin{gathered}
R_{m, t+1}=\alpha+\beta \cdot \sigma_{m, t+1 \mid t}^{2}+\epsilon_{m, t+1} \\
E_{t}\left(\epsilon_{m, t+1}^{2} \mid \Omega_{t}\right)=\sigma_{m, t+1 \mid t}^{2}=\theta_{0}+\theta_{1} \epsilon_{m, t}^{2}+\theta_{2} \sigma_{m, t}^{2}+\theta_{3} D_{t} \epsilon_{m, t}^{2} \\
D_{t}=1 \text { if } \epsilon_{m, t}<0, \text { and } D_{t}=0 \text { otherwise }
\end{gathered}
$$

where Eq. (9) allows positive and negative shocks to have different impacts on the conditional variance of the bond market. If $\theta_{3}$ is positive, the GJRGARCH model implies that negative (positive) shocks increase (decrease) the conditional variance of bond market returns.

Results for the GJRGARCH-in-Mean model are similar to those for the GARCH-in-Mean model, as shown in Panel B of Table A.1. The estimated slope coefficient on the conditional variance of the bond market is positive and significant: $\beta=18.12(t$-stat. $=2.47)$, whereas the estimate for the equity market becomes negative for the sample period $1997-2019, \beta=-0.98$ $(t$-stat. $=-0.38)$ and remains insignificant in the longer sample period, $0.72(t$-stat. $=1.03)$.

Overall, the intertemporal relation between expected return and risk in the bond market is significantly positive and robust, whereas there is no significant risk-return tradeoff in the equity market (consistent with earlier studies).

\subsection{Economic significance of the intertemporal risk-return tradeoff in the bond market}

In this section, we investigate the economic value of bond market forecasts based on the

variance of bond market returns. Following Kandel and Stambaugh (1996), Campbell and Thompson (2008), and Ferreira and Santa-Clara (2011), among others, we compute the cer- 
tainty equivalent return (CER) gain for a mean-variance investor who optimally allocates between the corporate bond market portfolio and the risk-free asset using the out-of-sample predictive regression forecasts.

At the end of month $t$, the investor optimally allocates $w_{t}$ of the portfolio to bonds and $1-w_{t}$ to the risk-free asset and earn the realized return at the end of month $t+1$ as

$$
\begin{gathered}
R_{t+1}^{p}=w_{t} R_{t+1}^{m}+\left(1-w_{t}\right) R_{t+1}^{f}, \\
\text { where } \quad w_{t}=\frac{1}{\gamma} \frac{\widehat{R}_{t+1}^{m}}{\widehat{\sigma}_{t+1}^{2}} .
\end{gathered}
$$

In Eq.(11), $\gamma$ is the risk aversion coefficient, $\widehat{R}_{t+1}^{m}$ is the out-of-sample forecast of the corporate bond market excess return, and $\widehat{\sigma}_{t+1}^{2}$ is the variance forecast. The CER of the portfolio is

$$
C E R_{p}=\widehat{\mu}_{p}-0.5 \gamma \widehat{\sigma}_{p}^{2}
$$

where $\widehat{\mu}_{p}$ and $\widehat{\sigma}_{p}^{2}$ are the sample mean and variance of the investor's portfolio over the forecasting evaluation period. The CER gain is the difference between the CER based on the forecast of market return generated by the realized market variance and the CER based on the historical average forecast. ${ }^{10}$ To examine the effect of risk aversion, we consider three levels; 10, 15, and 20, to be consistent with the risk aversion estimates in Table 1.

Table 2 shows that the bond market variance delivers large economic gains for a meanvariance investor. For the value-weighted bond index in Panel A, the CER gains for $\sigma_{m, t}^{2}$ across the risk aversion coefficients are consistently positive and economically large, ranging from $3.64 \%$ to $5.04 \%$. Specifically, an investor with a risk aversion of 10, 15, and 20 would be willing to pay an annual portfolio management fee up to $3.64 \%, 4.34 \%$, and $5.04 \%$, respectively, to have access to the intertemporal risk-return regressions in Eqs. (3)-(4). As expected, the fee increases with risk aversion. Contrary to the large CER gains from the market variance, macroeconomic variables proxying for business cycle fluctuations generate small economic

\footnotetext{
${ }^{10}$ We multiply this difference by 12 so that it can be interpreted as the annual portfolio management fee that an investor would be willing to pay to have access to the predictive regression forecast instead of the historical average forecast. We follow DeMiguel, Garlappi, and Uppal (2009) to assess the statistical significance of the CER gain.
} 
gains. For example, when the risk aversion is 10, EP, DP, BM, and DEF have negative CER gains of $-2.23 \%,-0.22 \%,-4.38 \%$, and $-2.70 \%$, respectively. The only exception is TERM which delivers positive economic gains in the range of $1.68 \%$ and $2.47 \%$, though the gains are still much smaller than those based on the bond market variance. As shown in Panel B of Table 2, the results are similar when we use the Merrill Lynch bond index as an alternative proxy of the bond market return.

In addition to the CER gains, we simulate the returns of a trading strategy based on the out-of-sample one-month-ahead forecasts of the bond market returns using its realized variance. For each month $t$, the strategy invests $100 \%$ in the bond market index if the forecasted excess return of bonds over the risk-free rate is greater than zero; otherwise it invests $100 \%$ in Treasury bills. At time $t+1$, the return of the portfolio is realized; a new regression using the expanding window is estimated and a new return forecast is computed. ${ }^{11}$ We find that for the out-of-sample period from January 2007 to June 2019, the market-timing strategy using $\mathrm{VW}^{\text {bond }}$ and its realized variance generates an average return of $0.55 \%$ per month with a standard deviation of $1.52 \%$ and a monthly Sharpe ratio of 0.32 , higher than many of the existing corporate bond market factors. ${ }^{12}$ Overall, Table 2 demonstrates that the bond market variance, $\sigma_{m, t}^{2}$, can generate sizable economic value for a mean-variance investor, and the results are robust to different risk aversion coefficients and different proxies for the corporate bond market returns.

\subsection{The intertemporal risk-return tradeoff in the equity market}

To make comparisons with the bond market, we now replicate the test in the equity market. Following French et al. (1987) and a number of follow-up studies, we estimate the time-series predictive regressions in Eq. (3) using the value-weighted CRSP index as a proxy for the U.S.

\footnotetext{
${ }^{11}$ The in-sample estimation period starts from January 1997 to December 2006 and the out-of-sample bond return forecasts spans January 2007 to June 2019. We choose the in-sample estimation period to be before the crisis in 2007 to investigate the performance of the market-timing strategy during the crisis period.

${ }^{12}$ During the same period from January 2007 to June 2019, the monthly Sharpe ratios for the default factor, term factor, downside risk factor, credit risk factor, and liquidity risk factor are $-0.09,0.22,0.24,0.15$, and 0.28 , respectively.
} 
equity market. Consistent with the findings in French et al. (1987), Goyal and Santa-Clara (2003), Ghysels et al. (2005), and Bali (2008), Table 3 shows that there exists no significant intertemporal relation between the realized variance and the one-month-ahead excess return of aggregate stock market portfolio.

For the same sample period as used in the bond market, January 1997 - June 2019, the estimated slope coefficient on the lagged realized variance is positive but statistically insignificant; $1.91(t$-stat.=0.76). When we use the longest sample period available at CRSP (July 1926-June 2019), the estimate remains insignificant, $0.53(t$-stat. $=0.79)$. Table 3 also shows that the adjusted $R^{2}$ values are close to zero: $0.05 \%$ for the $1926-2019$ period and $-0.14 \%$ for the 1997-2019 period, confirming the insignificant predictive power of the equity market risk. Controlling for the same set of variables (EP, DP, BM, DEF, TERM), we find no evidence of a significant time-series link between expected return and risk in the equity market.

To understand the contradictory findings on the risk-return tradeoff in the equity versus bond markets, we provide further investigation in Section 5.

\section{The Cross-Sectional Relation Between Expected Return and Risk}

After thoroughly investigating the time-series relation between risk and return in the bond market, in this section, we examine the cross-sectional relation between total, systematic, and idiosyncratic risk and future returns on individual corporate bonds. We first propose a new measure of systematic and idiosyncratic risk for corporate bonds. Second, we explore alternative factor models to calculate the risk-adjusted returns of bond portfolios sorted by systematic and idiosyncratic risk. Third, we present comprehensive evidence on the crosssectional relation between risk and future returns of corporate bonds using the portfolio-

level and bond-level Fama-MacBeth regressions. Finally, we test the relative performance of aggregate systematic vs. idiosyncratic risk in predicting future bond market returns and bond 
market volatility.

\subsection{Systematic and idiosyncratic risks of corporate bonds}

For each month, we use a 36-month rolling window to estimate the monthly variance (total risk) of corporate bonds:

$$
\sigma_{i, t}^{2}=\frac{1}{n-1} \sum_{t=1}^{n}\left(R_{i, t}-\bar{R}_{i}\right)^{2}
$$

where $R_{i, t}=r_{i, t}-r_{f, t}$ is the excess return on bond $i$ in month $t, \bar{R}_{i}=\frac{\sum_{t=1}^{n} R_{i, t}}{n}$ is the sample average of excess returns over the past 36 months $(n=36)$, and $\sigma_{i, t}^{2}$ is the sample variance of monthly excess returns over the past 36 months. A bond is included in the risk calculations if it has at least 24 monthly return observations in the 36-month rolling window before the test month.

After computing the total risk of each bond, we divide the total variance $\left(\sigma_{i}^{2}\right)$ into its systematic and idiosyncratic components. Our objective is to investigate whether the systematic and/or idiosyncratic component has significant predictive power on future corporate bond returns. We use the factor model of Bai, Bali, and Wen (2019) that introduces the downside risk, credit risk, and liquidity risk factors based on independently sorted bivariate portfolios of bond-level credit rating, value-at-risk, and illiquidity: ${ }^{13}$

$$
R_{i, t}=\alpha_{i}+\beta_{1, i} \cdot M K T_{t}+\beta_{2, i} \cdot D R F_{t}+\beta_{3, i} \cdot C R F_{t}+\beta_{4, i} \cdot L R F_{t}+\epsilon_{i, t}
$$

where $R_{i, t}$ is the excess return on bond $i$ in month $t$. Total risk of bond $i$ is measured by the variance of $R_{i, t}$ in Eq. (13), denoted by $\sigma_{i}^{2}$. Idiosyncratic (or residual) risk of bond $i$ is proxied by the variance of $\epsilon_{i, t}$ in Eq. (14), denoted by $\sigma_{\epsilon, i}^{2}$. Systematic risk of bond $i$ is defined as the difference between total and residual variance, $S R=\sigma_{i}^{2}-\sigma_{\epsilon, i}^{2}$, and it is a function of the variance of the $M K T, D R F, C R F$, and $L R F$ factors, the cross-covariances of the $M K T$,

\footnotetext{
${ }^{13} D R F$ is the downside risk factor, defined as the value-weighted average return difference between the highest-VaR portfolio minus the lowest-VaR portfolio within each rating portfolio. CRF is the credit risk factor, defined as the value-weighted average return difference between the highest credit risk portfolio minus the lowest credit risk portfolio within each illiquidity portfolio. $L R F$ is the liquidity risk factor, defined as the value-weighted average return difference between the highest illiquidity portfolio minus the lowest illiquidity portfolio within each rating portfolio.
} 
$D R F, C R F$, and $L R F$ factors, and the exposures of the bond's excess returns to the $M K T$, $D R F, C R F$, and $L R F$ factors (i.e., factor loadings). That is, systematic risk of bond $i$ is attributable to the overall volatility of the four factors as well as the factors' cross-covariances.

Motivated by the fact that downside risk, credit risk, and liquidity risk jointly play an important role in determining the expected bond returns, we introduce a new, composite measure of systematic risk of individual corporate bonds that integrates the covariances of these risk factors (DRF, CRF, LRF) as well as their own variances. We will show that the conventional measure of market risk, such as the market beta alone, is not sufficient to capture the broad systematic risk in the corporate bond market.

\subsection{Alternative factor models}

We consider three different factor models to estimate the risk-adjusted returns (alphas) of corporate bond portfolios sorted by total, systematic, and idiosyncratic risk.

The first one is the 5-factor model with equity market factors, including the excess return on the market portfolio proxied by the value-weighted stock market index $\left(\mathrm{MKT}^{\text {Stock}}\right)$ in the Center for Research in Security Prices (CRSP), the size factor (SMB), the book-to-market factor (HML), the momentum factor $\left(\mathrm{MOM}^{\text {Stock }}\right)$, and the liquidity risk factor $\left(\mathrm{LIQ}^{\text {Stock }}\right)$, following Fama and French (1993), Carhart (1997), and Pastor and Stambaugh (2003). ${ }^{14}$

The second one is the 5-factor model with bond market factors, including aggregate corporate bond market $(\mathrm{MKT})$, the default spread factor (DEF), the term spread factor (TERM), the bond liquidity factor $\left(\mathrm{LIQ}^{\text {Bond }}\right)$, and the bond momentum factor $\left(\mathrm{MOM}^{\text {Bond }}\right)$, following Fama and French (1993), Elton, Gruber, and Blake (1995), Lin, Wang, and Wu (2011), and Jostova et al. (2013). Following Fama and French (1993), we define the default factor (DEF) as the difference between the return on a market portfolio of long-term corporate bonds (the composite portfolio on the corporate bond module from Ibbotson Associates) and the

\footnotetext{
${ }^{14}$ The factors $\mathrm{MKT}^{\text {Stock }}$ (excess market return), SMB (small minus big), HML (high minus low), MOM (winner minus loser), and LIQ (liquidity risk) are described in and obtained from Kenneth French's and Lubos Pastor's online data libraries: http://mba.tuck.dartmouth.edu/pages/faculty/ken.french/ and http://faculty.chicagobooth.edu/lubos.pastor/research/.
} 
long-term government bond return, and we define the term factor (TERM) as the difference between the monthly long-term government bond return (from Ibbotson Associates) and the one-month Treasury bill rate. Following Jostova et al. (2013) and Bali et al. (2020), the bond momentum factor $\left(\mathrm{MOM}^{\text {Bond }}\right)$ is constructed from $5 \times 5$ bivariate portfolios of credit rating and bond momentum, defined as the cumulative returns over months from $t-7$ to $t-2$ (formation period). We construct the liquidity risk factor $\left(\mathrm{LIQ}^{\text {Bond }}\right)$ in line with Lin, Wang, and $\mathrm{Wu}(2011)$.

The third one is the 10-factor model combining the five equity market factors and the five bond market factors described above.

Panel A of Table 4 shows that bonds in our sample have an average systematic risk of $0.13 \%$ with a standard deviation of $0.27 \%$. Panel B presents the correlation matrix between SR and the other bond characteristics. Following Bai, Bali, and Wen (2019), our proxy for downside risk is the $5 \%$ Value-at-Risk (VaR), the second lowest monthly return observation over the past 36 months. ${ }^{15}$ Following Roll (1984), bond-level illiquidity is proxied by the autocovariance of daily bond price changes within each month. As shown in Panel B, systematic risk is positively associated with rating, maturity, downside risk, and bond-level illiquidity, with respective correlations of $0.342,0.124,0.623$, and 0.184 . These numbers indicate that bonds with higher credit risk, longer maturity (proxying for higher interest rate risk), higher downside risk, and lower liquidity have higher systematic risk. Bond size is negatively correlated with systematic risk, implying that smaller and illiquid bonds have higher systematic risk.

\subsection{The cross-sectional relation between systematic risk and ex- pected bond returns}

We first test the significance of a cross-sectional relation between systematic risk and future bond returns using portfolio-level analysis. For each month from January 1997 to June 2019, we form value-weighted univariate portfolios by sorting corporate bonds into quintiles based

\footnotetext{
${ }^{15}$ Following BBW, we multiply the original VaR measure by -1 so that a higher value is associated with higher downside risk for convenience of interpretation.
} 
on their systematic risk (SR), where quintile 1 contains bonds with the lowest SR and quintile 5 contains bonds with the highest SR. Table 5 shows, for each quintile, the average systematic risk of bonds, the next month average excess return, the 5-factor alpha from stock market factors, the 5-factor alpha from bond market factors, and the 10-factor alpha from both stock and bond market factors. The last six columns report the average bond characteristics for each quintile, including the bond market beta, illiquidity, downside risk, credit rating, time-tomaturity, and bond size. The last row displays the differences in the average returns and the alphas between quintile 5 and quintile 1. The average excess returns and alphas are defined in terms of monthly percentages. Newey-West (1987) adjusted $t$-statistics with six lags are reported in parentheses.

Moving from quintile 1 to quintile 5, the average excess return on the SR-sorted portfolios increases monotonically from $0.19 \%$ to $1.03 \%$ per month. This indicates a monthly average return difference of $0.85 \%$ between quintiles 5 and 1 with a Newey-West $t$-statistic of 3.64, implying that this positive return difference is economically and statistically significant. This result shows that corporate bonds in the highest SR quintile generate $10.20 \%$ per annum higher average return than bonds in the lowest SR quintile do.

In addition to the average excess returns, Table 5 presents the intercepts (alphas) from the regression of the quintile excess portfolio returns on a constant, the excess stock market return $\left(\mathrm{MKT}^{\text {Stock}}\right)$, the size factor $(\mathrm{SMB})$, the book-to-market factor (HML), the momentum factor (MOM), and the liquidity factor (LIQ) described in Section 4.2. The third column of Table 5 shows that, similar to the average excess returns, the 5-factor alpha from stock market factors also increases monotonically from $0.15 \%$ to $0.76 \%$ per month, moving from the low-SR to the high-SR quintile, indicating a positive and significant alpha spread of $0.61 \%$ per month $(t$-stat. $=2.51)$.

Beyond the well-known stock market factors, we also test whether the significant return difference between High-SR bonds and Low-SR bonds is explained by prominent bond market factors. Similar to our earlier findings from the average excess returns and the 5-factor alphas 
from stock market factors, the fourth column of Table 5 shows that, moving from the lowSR to the high-SR quintile, the 5-factor alpha from bond market factors increases almost monotonically from $0.06 \%$ to $0.80 \%$ per month. The corresponding 5 -factor alpha spread between quintiles 5 and 1 is positive and highly significant: $0.73 \%$ per month with a $t$-statistic of 3.25. The fifth column of Table 5 presents the 10-factor alpha for each quintile from the combined five stock and five bond market factors. Consistent with our earlier results, the 10factor alpha is $0.62 \%$ per month with a $t$-statistic of 2.46 . Overall, these results indicate that the commonly used stock and bond market factors do not explain the significantly positive systematic risk premium in the corporate bond market. ${ }^{16}$

Next, we investigate the source of the significant risk-adjusted return (alpha) spread between the high- and low-SR bonds. As reported in Table 5, the 10-factor alpha in quintile 1 (low-SR bonds) is economically and statistically insignificant, whereas the 10-factor alpha in quintile 5 (high-SR bonds) is positive and highly significant. Hence, we conclude that the significantly positive alpha spread between the high- and low-SR bonds is due to the outperformance by high-SR bonds (long leg of the arbitrage portfolio), but not due to the underperformance by low-SR bonds (short leg of the arbitrage portfolio). ${ }^{17}$

Finally, we examine the average characteristics of SR-sorted bond portfolios. As shown in the last six columns of Table 5, high-SR bonds have higher bond market beta, lower liquidity, higher downside risk, lower credit quality, and longer maturity. These results indicate that bonds with higher systematic risk have higher market, credit, and downside risk and have lower liquidity. Thus, we will test whether the systematic risk premium is explained by the aforementioned risk and liquidity characteristics of corporate bonds in bivariate portfolio sorts

\footnotetext{
${ }^{16}$ Our finding of a significantly positive systematic risk premium in the bond market is also consistent with Koijen, Lustig, and Van Nieuwerburgh (2017) showing that bond factors which predict future economic activity at business cycle horizons are priced in the cross-section of bond returns, highlighting the role of systematic risk in the bond market.

${ }^{17}$ In Table A.2 of the online appendix, we test the significance of a cross-sectional relation between total risk (volatility) and future bond returns. Similar to our findings in Table 5 for SR-sorted portfolios, Table A.2 shows that the average return and alpha spreads between high-VOL and low-VOL quintiles are positive and highly significant and the significantly positive alpha spread is driven by the outperformance of high-volatility bonds, but not due to the underperformance of low-volatility bonds.
} 
and multivariate regressions.

\subsection{Is there an IVOL puzzle in the corporate bond market?}

In sharp contrast to the findings in Table 5, Table 6 presents evidence for the poor performance of idiosyncratic risk (IR) in predicting the cross-sectional variation in future bond returns. Compared to Table 5, the average return spread between quintiles 5 and 1 in Table 6 is weaker

economically: $0.45 \%$ per month $(t$-stat. $=2.14)$. More importantly, the 10-factor alpha spread between the high-IR and low-IR quintiles is economically and statistically insignificant at $0.17 \%$ per month $(t$-stat. $=1.16)$. These results show that the standard bond market factors explain the average return spread in idiosyncratic volatility-sorted portfolios.

As discussed earlier, corporate bonds are primarily held by institutional investors. The insignificant 10-factor alpha spread in Table 6 suggests that institutional investors in the corporate bond market are able to create well-diversified portfolios with a small exposure to bond-specific risk so that idiosyncratic volatility does not command a significant risk premium in the bond market. Since institutional investors do not demand compensation for not being able to diversify firm-specific risk, there exists no significant relation between idiosyncratic risk and future bond returns, consistent with the theoretical models of Levy (1978) and Merton (1987). Thus, we conclude that there is no IVOL puzzle in the corporate bond market.

\subsection{Bivariate portfolios of systematic risk and idiosyncratic risk}

In this section, we investigate the predictive power of systematic and idiosyncratic risk while accounting for the interaction between them. Specifically, we perform a bivariate portfolio analysis for systematic risk by controlling for idiosyncratic risk, and then we conduct the same test for idiosyncratic risk while controlling for systematic risk.

\subsubsection{Bivariate portfolios of systematic risk controlling for idiosyncratic risk}

We first test whether the positive relation between systematic risk and future bond returns remains significant after controlling for idiosyncratic risk. To perform this test, we form 
quintile portfolios every month from January 1997 to June 2019 by first sorting corporate bonds into five quintiles based on their idiosyncratic risk. Then, within each IR-sorted portfolio, bonds are further sorted into five sub-quintiles based on their systematic risk. This methodology produces sub-quintile bond portfolios with dispersion in SR but nearly identical IR values under each IR-sorted quintile. SR,1 represents the lowest SR-ranked bond quintiles within each of the five IR-ranked quintiles. Similarly, SR,5 represents the highest SR-ranked quintiles within each of the five IR-ranked quintiles. Panel A of Table 7 shows the average systematic risk and the next month average return for each quintile. Moving from portfolio SR,1 to SR,5, the average return increases almost monotonically from $0.44 \%$ to $1.21 \%$ per month. The average return difference between portfolio SR,5 and SR,1 (i.e., high-SR bonds versus low-SR bonds) is $0.77 \%$ per month with a $t$-statistic of 2.73 , indicating that the positive relation between systematic risk and future bond returns remains significant after controlling for idiosyncratic risk.

We also check whether this significant return spread between portfolio SR, 5 and portfolio SR,1 is explained by established equity and bond market factors. The 5-factor stock, 5-factor bond, and 10-factor alpha spreads are all positive at $0.71 \%, 0.65 \%$, and $0.59 \%$ per month, and statistically significant. Thus, first controlling for idiosyncratic risk and then controlling for stock and bond market factors, the risk-adjusted return spread between the high-SR and low-SR bonds remains positive and significant.

\subsubsection{Bivariate portfolios of idiosyncratic risk controlling for systematic risk}

We now investigate the relation between idiosyncratic risk and future bond returns after controlling for systematic risk. To perform this test, we reverse the portfolio sorting in the above subsection and rank corporate bonds first by SR, and then by IR within each SR-sorted portfolio. In Table 7, Panel B shows that the average return spread between portfolio IR, 5 and IR, 1 is positive but economically small, $0.11 \%$ per month, and statistically insignificant with a $t$-statistic of 0.78 , indicating that the significant relation between idiosyncratic risk and future 
raw returns disappears after controlling for systematic risk. In addition, the differences in the 5-factor stock, 5-factor bond, and 10-factor alphas are all economically small and statistically insignificant. Overall, the bivariate portfolio analyses indicate that compared to idiosyncratic risk, the composite measure of systematic risk is a more powerful determinant of the crosssectional variation in corporate bond returns.

\subsection{Fama-MacBeth cross-sectional regressions}

We have so far tested the significance of systematic and idiosyncratic risk measures as determinants of the cross-section of future bond returns at the portfolio level. To examine their impact simultaneously, we use Fama and MacBeth (1973) regressions and control for other risk characteristics, including the bond market beta, default beta, term beta, bond-level illiquidity, credit rating, year-to-maturity, bond amount outstanding, and lagged bond return. ${ }^{18}$ Monthly cross-sectional regressions are run for the following specification and nested versions thereof:

$$
R_{i, t+1}=\lambda_{0, t}+\lambda_{1, t} \cdot S R_{i, t}+\lambda_{2, t} \cdot I R_{i, t}+\sum_{k=1}^{K} \lambda_{k, t} \cdot \text { Control }_{k, t}+\varepsilon_{i, t+1}
$$

where $R_{i, t+1}$ is the excess return on bond $i$ in month $t+1$.

Table 8 reports the time series average of the intercept, slope coefficients $(\lambda$ 's), and the adjusted $R^{2}$ values over the 252 months from January 1997 to June 2019. The univariate regression results confirm those obtained from the portfolio analysis. In Regression (1), the average slope, $\lambda_{1, t}$, from the monthly regressions of excess returns on SR alone is 1.828 with a $t$-statistic of 4.33. The economic magnitude of the associated effect is similar to that documented in Table 5. The spread in average SR between low-SR and high-SR portfolios is approximately $0.50 \%$, and multiplying this spread by the average slope of 1.828 produces an estimated monthly return difference of 91 basis points. ${ }^{19}$ Similarly, the estimate of idiosyn-

\footnotetext{
${ }^{18}$ The bond market beta $\left(\beta^{M K T}\right)$, default beta $\left(\beta^{D E F}\right)$, and term beta $\left(\beta^{T E R M}\right)$ are the risk exposures to aggregate bond market factor, the default factor, and the term factor obtained from a 36-month rolling window estimation.

${ }^{19}$ Note that the ordinary least squares (OLS) methodology used in the Fama-MacBeth regressions gives an
} 
cratic risk premium, $\lambda_{2, t}$, is positive and significant in univariate regression (2), consistent with the significantly positive raw return spread reported in Table 6 . When including both SR and IR in regression (3), systematic risk premium remains significant, while idiosyncratic risk premium disappears. This finding is consistent with the bivariate portfolio results reported in Table 7.

After controlling for various bond characteristics in regressions (4)-(6), the results remain robust that there is no premium for idiosyncratic risk, but a significantly positive premium for systematic risk. These results show that the newly proposed composite measure of systematic risk has distinct information beyond bond size, maturity, rating, liquidity, market risk, and default risk, and that it is a strong and robust predictor of future bond returns.

Our findings are consistent with theoretical predictions. We attribute the theoretical alignment to the fact that we construct an economically sensible measure of systematic risk not only because we choose robust risk factors that capture common variation in corporate bond returns, but also because of the way we synthesize information over these factors. Our systematic risk measure is a function that synthesizes the variance of the underlying factors, the cross-covariances of the factors, and the exposures of bond returns to the factors. Motivated by the fact that downside risk, credit risk, and liquidity risk jointly play an important role in determining expected bond returns, one needs a comprehensive measure that can integrate the covariances of these risk factors as well as their own variances. Thus, the conventional measure of market risk, such as the market beta alone, is not sufficient to capture the broad systematic risk in the corporate bond market, as shown by the insignificant average slope coefficients on $\beta^{M K T}$.

\subsection{Robustness check}

We conduct several robustness checks on the predictive power of systematic risk and present the results in the online appendix (Tables A.3 to A.6). Our results show that the predictive equal weight to each cross-sectional observation so that the regression results are more aligned with the equalweighted portfolios. That is why the economic significance of SR obtained from Fama-MacBeth regressions, $0.91 \%$ per month, is somewhat higher than the $0.85 \%$ per month obtained from the value-weighted portfolios (see Table 5). 
power of SR for future bond returns (i) is significantly positive for both investment-grade and non-investment-grade bonds, (ii) remains economically and statistically significant for different subperiods from January 1997 to June 2019 (including the crisis and the postcrisis/recovery periods), and (iii) is robust to using firm-level regressions by picking one bond with median size or the most liquid bond as a representative bond of the firm.

\subsection{The nexus of the cross-section and time-series predictability}

Cochrane (2005) and Maio and Santa-Clara (2012) investigate the ICAPM restrictions in the cross-section and time-series predictability, and show that the cross-sectional variable (when aggregated) should predict future market return and market volatility if the variable can be interpreted as the state variable that affects investment opportunity set in the ICAPM. In this subsection, we provide novel evidence in the bond market supporting this interpretation.

We construct three aggregate measures of systematic risk using different weighting schemes, namely, the equal-weighted, value-weighted, and rating-weighted cross-sectional average of bond-level systematic risk, and investigate their predictive power for future returns and volatility of aggregate bond market portfolio. Fig.1 plots the time-series of aggregate systematic risk over the sample period from January 1997 to June 2019. The three measures are highly correlated with an average correlation coefficient of 0.95, and all spike during the Great Recession. $^{20}$ To test the time-series predictive power of aggregate systematic risk, we control for a large set of macroeconomic variables proxying for business cycle fluctuations:

$$
Y_{t+\tau}=\alpha+\lambda_{1} \cdot S R_{t}+\lambda_{2} \cdot X_{t}^{k}+\epsilon_{t+1}, \quad k=1, \ldots, 6 ; \quad \tau=1,2, \ldots, 12
$$

where $Y_{t+\tau}$ is one of the two dependent variables: bond market excess return (VW ${ }^{\text {bond }}$ ) and bond market variance $\left(\mathrm{MKT}^{V O L}\right)$, calculated as the sum of squared daily bond market returns in a month. $X_{t}^{k}$ is a vector of control variables similar to those used in Eq. (5).

\footnotetext{
${ }^{20} \mathrm{As}$ a result, we use the value-weighted average systematic risk $\left(\mathrm{SR}^{V W}\right)$ in our time-series predictive regressions. Table A.7 of the online appendix shows that the results are similar when we use the equal- and rating-weighted aggregate measures.
} 
Table 9 presents the performance of aggregate systematic risk in predicting $\tau$-month ahead aggregate bond market returns and bond market volatility for different horizons $(\tau=$ $1,2, \ldots, 12)$. Panel A shows that the estimated slope coefficients, $\lambda_{1}$, in Eq. (16) are significantly positive, indicating the strong predictive power of aggregate systematic risk on future bond market returns up to 9 months, even after controlling for a number of time-series return predictors. Further, the adjusted $R^{2}$ values are very high compared to those presented in earlier studies for the equity market. ${ }^{21}$ Panel B shows that aggregate systematic risk positively predicts future bond market volatility up to six months into the future. Both sets of results suggest that the composite measure of systematic risk satisfies the ICAPM restrictions on the time-series and cross-sectional predictability.

In sharp contrast to the strong predictability of aggregate systematic risk, Table 10 shows that aggregate idiosyncratic risk does not have any predictive power for future bond market returns or volatility. None of the estimated slope coefficients on aggregate idiosyncratic risk is significant for any forecasting horizon in either Panel A or Panel B.

The time-series predictability of aggregate systematic risk in this subsection resonates the findings in Section 3, both corroborating the significance of a positive intertemporal risk-return tradeoff in the corporate bond market.

\section{Investigating the Role of Systematic and Idiosyncratic Risk in the Bond and Equity Markets}

In this section, we examine the different roles played by systematic and idiosyncratic risk in the cross-sectional pricing of equities versus bonds. First, we propose a similar measure of systematic risk for individual stocks and revisit the IVOL puzzle in the equity market. Then, we explore the impact of the investor clientele on the predictive power of idiosyncratic risk

\footnotetext{
${ }^{21}$ The strong predictive power of SR in Table 9 is consistent with Table A.8 in the online appendix, which reports the significant time-series predictive power of the value-, equal-, and rating-weighted average of total variance of individual bonds for the one-month-ahead bond market returns.
} 
for future stock and bond returns.

\subsection{Revisiting the IVOL puzzle in the equity market}

Our composite measure of systematic risk for corporate bonds is a function of the variance of the underlying bond factors, the cross-covariances of the factors, and the bond exposures to these factors. Thus, the key input to construct a sound measure of systematic risk is to use economically sensible risk factors that capture common return variation in corporate bonds and that provide an accurate characterization of firm fundamentals.

In this section, we propose a similar comprehensive measure of systematic risk for individual stocks using the powerful equity factor models proposed by Fama and French (2015) and Hou, Xue, and Zhang (2015). Specifically, we construct a composite measure of systematic risk for individual stocks based on the five-factor model of Fama and French (2015) in Eq. (17) and the four-factor model of Hou, Xue, and Zhang (2015) in Eq. (18):

$$
\begin{gathered}
R_{i, d}=\alpha_{i}+\beta_{1, i} \cdot M K T_{d}^{S t o c k}+\beta_{2, i} \cdot S M B_{d}+\beta_{3, i} \cdot H M L_{d}+\beta_{4, i} \cdot R M W_{d}+\beta_{5, i} \cdot C M A_{d}+\epsilon_{i, d} \\
R_{i, d}=\alpha_{i}+\beta_{1, i} \cdot M K T_{d}^{S t o c k}+\beta_{2, i} \cdot M E_{Q, d}+\beta_{3, i} \cdot R O E_{Q, d}+\beta_{4, i} \cdot I A_{Q, d}+\epsilon_{i, d}
\end{gathered}
$$

where $R_{i, d}$ is the excess return of stock $i$ on day $d$. In Eq. (17), $M K T_{d}^{\text {Stock }}, S M B_{d}, H M L_{d}$, $R M W_{d}$, and $C M A_{d}$ in) are the daily equity market, size, book-to-market, profitability, and investment factors of Fama and French (2015). In Eq. (18), $M E_{Q, d}, R O E_{Q, d}$, and $I A_{Q, d}$ are the daily size, profitability, and investment Q factors of Hou, Xue, and Zhang (2015). ${ }^{22}$

The total risk of stock $i$ is measured by the variance of $R_{i, d}\left(\sigma_{i}^{2}\right)$, calculated as the sum of squared daily returns in a month. Idiosyncratic risk is measured by the variance of $\epsilon_{i, d}\left(\sigma_{\epsilon, i}^{2}\right)$. Systematic risk is thus the difference between the total and residual variance, $S R=\sigma_{i}^{2}-\sigma_{\epsilon, i}^{2}$. Following Ang et al. (2006) and subsequent work on idiosyncratic volatility in the equity

${ }^{22}$ The $M K T, S M B, H M L, R M W$, and $C M A$ factors of Fama-French (2015) are obtained from the data library (http://mba.tuck.dartmouth.edu/pages/faculty/ken.french/) for the longest sample period from July 1963 to June 2019. The $\mathrm{Q}$ factors $\left(M E_{Q}, R O E_{Q}\right.$, and $\left.I A_{Q}\right)$ of Hou, Xue, and Zhang (2015) are obtained from the data library (http://global-q.org/index.html) for the long sample period from January 1967 to June 2019. 
market, Eqs. (17) and (18) are estimated using daily returns over the past month, requiring at least 15 daily return observations in a month. ${ }^{23}$

Table 11 presents results from the value-weighted univariate portfolios of stocks sorted separately by systematic risk and idiosyncratic risk. Consistent with the IVOL puzzle in the equity market, systematic risk estimated either with Eq. (17) or (18) does not predict the cross-sectional variation in equity returns, whereas the IVOL puzzle remains significant in the equity market. One potential explanation is that investors hold concave preferences thus like positive skewness. If positive skewness is a desirable characteristic of a return distribution, then the fact that diversification destroys portfolio skewness makes investors to be willing to hold a limited number of stocks in their portfolios. ${ }^{24}$

Since individual investors do not hold a large number of stocks in their portfolios, they are unable to diversify firm-specific risk. Thus, according to the theoretical models of Levy (1978) and Merton (1987), stocks with higher idiosyncratic risk require higher returns to compensate for imperfect diversification, justifying a positive (not negative) cross-sectional relation between idiosyncratic risk and future equity returns. Since the IVOL puzzle is known to be significant only in the sample of stocks largely held by individual investors (to be confirmed in the next section), we conclude that retail investors' demand for positive skewness dominates their aversion to volatility so that retail investors prefer to hold a small number of lottery-like stocks with large positive skewness. Given that lottery stocks tend to have high idiosyncratic volatility and low future returns, retail investors' preference for lottery-like securities show some promise in solving the idiosyncratic volatility puzzle in the equity market (e.g., Kumar, 2009; Bali et al., 2011; Hou and Loh, 2016).

\footnotetext{
${ }^{23}$ We also use monthly data in estimating idiosyncratic volatility of individual stocks, to be consistent with the method in Section 4. The findings remain similar to those obtained from the daily data.

${ }^{24}$ The literature shows that the portfolios of individual investors are, in general, not well-diversified. For example, Goetzmann and Kumar (2008) find that the median number of stocks in a portfolio of individual investors is three in the 1991-1996 period. Odean (1999) and Barber and Odean (2001) also report the median number of stocks in individual investors' portfolios as two to three.
} 


\subsection{The investor clientele effect in the equity and bond markets}

The Flow of Funds report released by the Federal Reserve Board shows the composition of investors in the U.S. equity and corporate bond markets. Over the period of 1986 to 2019, the primary holders of corporate bonds are institutional investors (78\% on average), in particular, insurance companies, mutual funds, and pension funds, whereas the main holders of equities are retail investors (household sector, 43\%), then mutual funds (33\%) and pension funds (15\%). Since equities and bonds are mainly held by different groups of investors, retail vs. institutional investors, the difference in investor preferences and clienteles can be a plausible cause for the significance of systematic risk (idiosyncratic risk) in the bond (equity) market.

We first investigate the effect of the investor clientele on the predictive power of idiosyncratic risk for future stock returns. To perform this task, we form quintile portfolios every month from January 1980 to June 2019 by sorting individual stocks into portfolios based on institutional ownership, then within each ownership portfolio, we further sort stocks into subquintiles based on their idiosyncratic risk. Table 12 shows that the negative cross-sectional relation between idiosyncratic risk and future returns is more pronounced among stocks with low institutional ownership (i.e., stocks largely held by retail investors). More importantly, the IVOL puzzle disappears among stocks with high institutional ownership. This result is consistent with the evidence provided by Kumar (2009) and Han and Kumar (2013) that retail investors tend to be more attracted to high volatility stocks because of their lottery-like features, and such behavior leads to the negative cross-sectional relation between idiosyncratic volatility and future stock returns.

We conduct a similar analysis for corporate bonds using Thompson Reuter's eMAXX bond holdings data. This dataset has a comprehensive coverage of quarterly fixed income holdings for U.S. institutional investors such as insurance companies and mutual funds. For a given bond $i$ in quarter $t$, the measure of institutional ownership is defined as:

$$
I N S T_{i t}=\sum_{j}\left(\frac{\text { Holding }_{i j t}}{\text { OutstandingAmt }}\right)=\sum_{j} h_{j t}
$$


where Holding ijt $_{\text {is }}$ the par amount holdings of investor $j$ on bond $i$ during quarter $t$, OutstandingAmt $t_{i t}$ is bond $i$ 's outstanding amount, and $h_{j t}$ is the fraction of the outstanding amount held by investor $j$, in percentage.

We examine whether the idiosyncratic volatility effect in corporate bonds is uniform across bonds with high and low institutional ownership. ${ }^{25}$ Specifically, we form value-weighted bivariate portfolios by sorting corporate bonds into $5 \times 5$ quintile portfolios based on institutional ownership and idiosyncratic volatility estimated in Eq. (14). Table 13 reports the 10-factor alpha for each of the 25 portfolios at month $t+1$ and shows that the alpha spread between high-IR and low-IR quintiles is economically small and statistically insignificant in all quintiles of institutional ownership. Moreover, the magnitude of the alpha spreads is uniformly insignificant across all INST quintiles.

\section{Conclusion}

This paper provides time-series and cross-sectional evidence on the significance of a riskreturn tradeoff in the corporate bond market. For the first time in the literature, we present evidence of a significantly positive intertemporal relation between expected return and risk of the aggregate bond market portfolio, while the literature has not yet reached an agreement on the existence of such a positive risk-return tradeoff for the equity market. Moreover, we show that the time-series predictability is driven solely by aggregate systematic risk instead of aggregate idiosyncratic risk.

The paper also proposes novel measures of systematic and idiosyncratic risk for individual corporate bonds and tests their significance in the cross-sectional pricing of corporate bonds. The portfolio-level analyses and the bond-level cross-sectional regressions both indicate that the newly proposed measure of systematic risk has a strong predictive power on future bond returns, and the positive systematic risk premium is driven by the outperformance of

\footnotetext{
${ }^{25}$ Our access to the eMAXX bond holdings data covers the period 2001-2017 so that our analysis on bond holdings is based on the sample period January 2001-December 2017.
} 
bonds with high systematic risk. Given the powerful presence of systematic risk in the crosssectional pricing of corporate bonds, the idiosyncratic volatility puzzle well-documented in the stock market no longer exists in the bond market. This finding suggests that the institutional investors dominating the bond market hold well-diversified portfolios with a negligible exposure to bond-specific risk so that idiosyncratic volatility does not command a significant risk premium in the bond market.

The contradictory findings of the significance of systematic risk (idiosyncratic risk) in the bond (equity) market is likely due to investor preferences and informational frictions in the bond versus equity market given that the bond (equity) market is dominated by institutional (retail) investors. 


\section{References}

Ang, A., Hodrick, R. J., Xing, Y., Zhang, X., 2006. The cross-section of volatility and expected returns. Journal of Finance 61, 259-299.

Auh, J. K., Bai, J., 2020. Cross-asset information synergy in mutual fund families, Working Paper, SSRN eLibrary.

Bai, J., Bali, T. G., Wen, Q., 2019. Common risk factors in the cross-section of corporate bond returns. Journal of Financial Economics 131, 619-642.

Bali, T. G., 2008. The intertemporal relation between expected returns and risk. Journal of Financial Economics 87, 101-131.

Bali, T. G., Cakici, N., Whitelaw, R. F., 2011. Maxing out: Stocks as lotteries and the cross-section of expected returns. Journal of Financial Economics 99, 427-446.

Bali, T. G., Engle, R. F., 2010. The intertemporal capital asset pricing model with dynamic conditional correlations. Journal of Monetary Economics 57, 377-390.

Bali, T. G., Subrahmanyam, A., Wen, Q., 2020. Long-term reversals in the corporate bond market. Journal of Financial Economics, Forthcoming.

Barber, B., Odean, T., 2001. Boys will be boys: Gender, overconfidence, and common stock investment. Quarterly Journal of Economics 116, 261-292.

Bessembinder, H., Kahle, K. M., Maxwell, W. F., Xu, D., 2009. Measuring abnormal bond performance. Review of Financial Studies 22, 4219-4258.

Bollerslev, T., 1986. Generalized autoregressive conditional heteroscedasticity. Journal of Econometrics $31,307-327$.

Bollerslev, T., Engle, R. F., Wooldridge, J., 1988. A capital asset pricing model with time-varying covariances. Journal of Political Economy 96, 116-131.

Bollerslev, T., Zhou, H., 2006. Volatility puzzles: a simple framework for gauging return-volatility regressions. Journal of Econometrics 131, 123-150.

Brandt, M., Kang, Q., 2004. On the relationship between the conditional mean and volatility of stock returns: a latent var approach. Journal of Financial Economics 72, 217-257.

Campbell, J., 1991. A variance decomposition for stock returns. The Economic Journal 101, 157-179.

Campbell, J., Thompson, S., 2008. Predicting the equity premium out of sample: Can anything beat the historical average? Review of Financial Studies 21, 1509-1531.

Campbell, J. Y., 1987. Stock returns and the term structure. Journal of Financial Economics 18, 373-399.

Campbell, J. Y., Hentchel, L., 1992. No news is good news: an asymmetric model of changing volatility in stock returns. Journal of Financial Economics 31, 281-318. 
Campbell, J. Y., Shiller, R. J., 1988. Stock prices, earnings, and expected dividends. Journal of Finance 43, 661-676.

Cao, J., Goyal, A., Xiao, X., Zhan, X., 2020. Implied volatility changes and corporate bond returns, Working Paper, SSRN eLibrary.

Carhart, M. M., 1997. On persistence in mutual fund performance. Journal of Finance 52, 57-82.

Chen, N.-F., Roll, R., Ross, S. A., 1986. Economic forces and the stock market. Journal of Business 59, 383-403.

Chordia, T., Goyal, A., Nozawa, Y., Subrahmanyam, A., Tong, Q., 2017. Are capital market anomalies common to equity and corporate bond markets? Journal of Financial and Quantitative Analysis $52,1301-1342$.

Cochrane, J., 2005. Asset Pricing. Princeton University Press, Princeton, NJ.

DeMiguel, V., Garlappi, L., Uppal, R., 2009. Optimal versus naive diversification: How inefficient is the 1/n portfolio strategy? Review of Financial Studies 22, 1915-1953.

Edwards, A. K., Harris, L. E., Piwowar, M. S., 2007. Corporate bond market transaction costs and transparency. Journal of Finance 62, 1421-1451.

Elton, E. J., Gruber, M. J., Blake, C., 1995. Fundamental economic variables, expected returns, and bond fund performance. Journal of Finance 50, 1229-1256.

Engle, R. F., Lilien, D. M., Robins, R. P., 1987. Estimating time varying risk premia in the term structure: The arch-m model. Econometrica 55, 391-407.

Fama, E. F., 1990. Stock returns, expected returns, and real activity. Journal of Finance 45, 10891108.

Fama, E. F., French, K. R., 1988. Dividend yields and expected stock returns. Journal of Financial Economics 22, 3-25.

Fama, E. F., French, K. R., 1989. Business conditions and expected returns on stocks and bonds. Journal of Financial Economics 25, 23-49.

Fama, E. F., French, K. R., 1993. Common risk factors in the returns on stocks and bonds. Journal of Financial Economics 33, 3-56.

Fama, E. F., French, K. R., 2015. A five-factor asset pricing model. Journal of Financial Economics $116,1-22$.

Fama, E. F., MacBeth, J. D., 1973. Risk, return, and equilibrium: Empirical tests. Journal of Political Economy 81, 607-636.

Ferreira, M., Santa-Clara, P., 2011. Forecasting stock market returns: The sum of the parts is more than the whole. Journal of Financial Economics 100, 514-537.

Ferson, W. E., Harvey, C. R., 1991. The variation of economic risk premiums. Journal of Political Economy 99, 385-415. 
French, K. R., Schwert, G., Stambaugh, R., 1987. Expected stock returns and volatility. Journal of Financial Economics 19, 3-29.

Ghysels, E., Santa-Clara, P., Valkanov, R., 2005. There is a risk-return trade-off after all. Journal of Financial Economics 76, 509-548.

Glosten, L., Jagannathan, R., Runkle, D., 1993. On the relation between the expected value and the volatility of the nominal excess returns on stocks. Journal of Finance 48, 1779-1801.

Goetzmann, W. N., Kumar, A., 2008. Equity portfolio diversification. Review of Finance 12, 433-463.

Goyal, A., Santa-Clara, P., 2003. Idiosyncratic risk matters! Journal of Finance 58, 975-1007.

Goyal, A., Welch, I., 2008. A comprehensive look at the empirical performance of equity premium prediction. Review of Financial Studies 21, 1455-1508.

Graham, J., Leary, M., Roberts, M., 2015. A century of capital structure: The leveraging of corporate america. Journal of Financial Economics 118, 658-683.

Guo, H., Whitelaw, R., 2006. Uncovering the risk-return relation in the stock market. Journal of Finance 61, 1433-1463.

Han, B., Kumar, A., 2013. Speculative retail trading and asset prices. Journal of Financial and Quantitative Analysis 48, 377-404.

Harrison, P., Zhang, H., 1999. An investigation of the risk and return relation at long horizons. Review of Economics and Statistics 81, 399-408.

Harvey, C. R., 2001. The specification of conditional expectations. Journal of Empirical Finance 8, 573-637.

Hirshleifer, D., 1988. Residual risk, trading costs, and commodity futures risk premia. Review of Financial Studies 1, 173-193.

Hou, K., Loh, R., 2016. Have we solved the idiosyncratic volatility puzzle? Journal of Financial Economics 121, 167-194.

Hou, K., Xue, C., Zhang, L., 2015. Digesting anomalies: an investment approach. Review of Financial Studies 28, 650-705.

Jostova, G., Nikolova, S., Philipov, A., Stahel, C., 2013. Momentum in corporate bond returns. Review of Financial Studies 26, 1649-1693.

Kandel, S., Stambaugh, R., 1996. On the predictability of stock returns: An asset allocation perspective. Journal of Finance 51, 385-424.

Kapadia, N., Pu, X., 2012. Limited arbitrage between equity and credit markets. Journal of Financial Economics 105, 542-564.

Keim, D. B., Stambaugh, R. F., 1986. Predicting returns in the stock and bond markets. Journal of Financial Economics 17, 357-390.

Koijen, R., Lustig, H., Nieuwerburgh, S. V., 2017. The cross-section and time-series of stock and bond returns. Journal of Monetary Economics 88, 50-69. 
Kumar, A., 2009. Who gambles in the stock market? Journal of Finance 64, 1889-1933.

Levy, H., 1978. Equilibrium in an imperfect market: a constraint on the number of securities in the portfolio. American Economic Review 68, 643-658.

Lin, H., Wang, J., Wu, C., 2011. Liquidity risk and the cross-section of expected corporate bond returns. Journal of Financial Economics 99, 628-650.

Maio, P., Santa-Clara, P., 2012. Multifactor models and their consistency with the icapm. Journal of Financial Economics 106, 586-613.

Merton, R. C., 1973. An intertemporal capital asset pricing model. Econometrica 41, 867-887.

Merton, R. C., 1974. On the pricing of corporate debt: The risk structure of interest rates. Journal of Finance 29, 449-470.

Merton, R. C., 1980. On estimating the expected return on the market: An exploratory investigation. Journal of Financial Economics 8, 323-361.

Merton, R. C., 1987. A simple model of capital market equilibrium with incomplete information. Journal of Finance 42, 483-510.

Nelson, D., 1991. Conditional heteroskedasticity in asset returns: a new approach. Econometrica 59, 347-370.

Newey, W. K., West, K. D., 1987. A simple, positive semi-definite, heteroskedasticity and autocorrelation consistent covariance matrix. Econometrica 55, 703-708.

Odean, T., 1999. Do investors trade too much? American Economic Review 89, 1279-1298.

Pastor, L., Stambaugh, R. F., 2003. Liquidity risk and expected stock returns. Journal of Political Economy 111, 642-685.

Roll, R., 1984. A simple implicit measure of the effective bid-ask spread in an efficient market. Journal of Finance 39, 1127-1139.

Whitelaw, R. F., 1994. Time variations and covariations in the expectation and volatility of stock market returns. Journal of Finance 49, 515-541. 


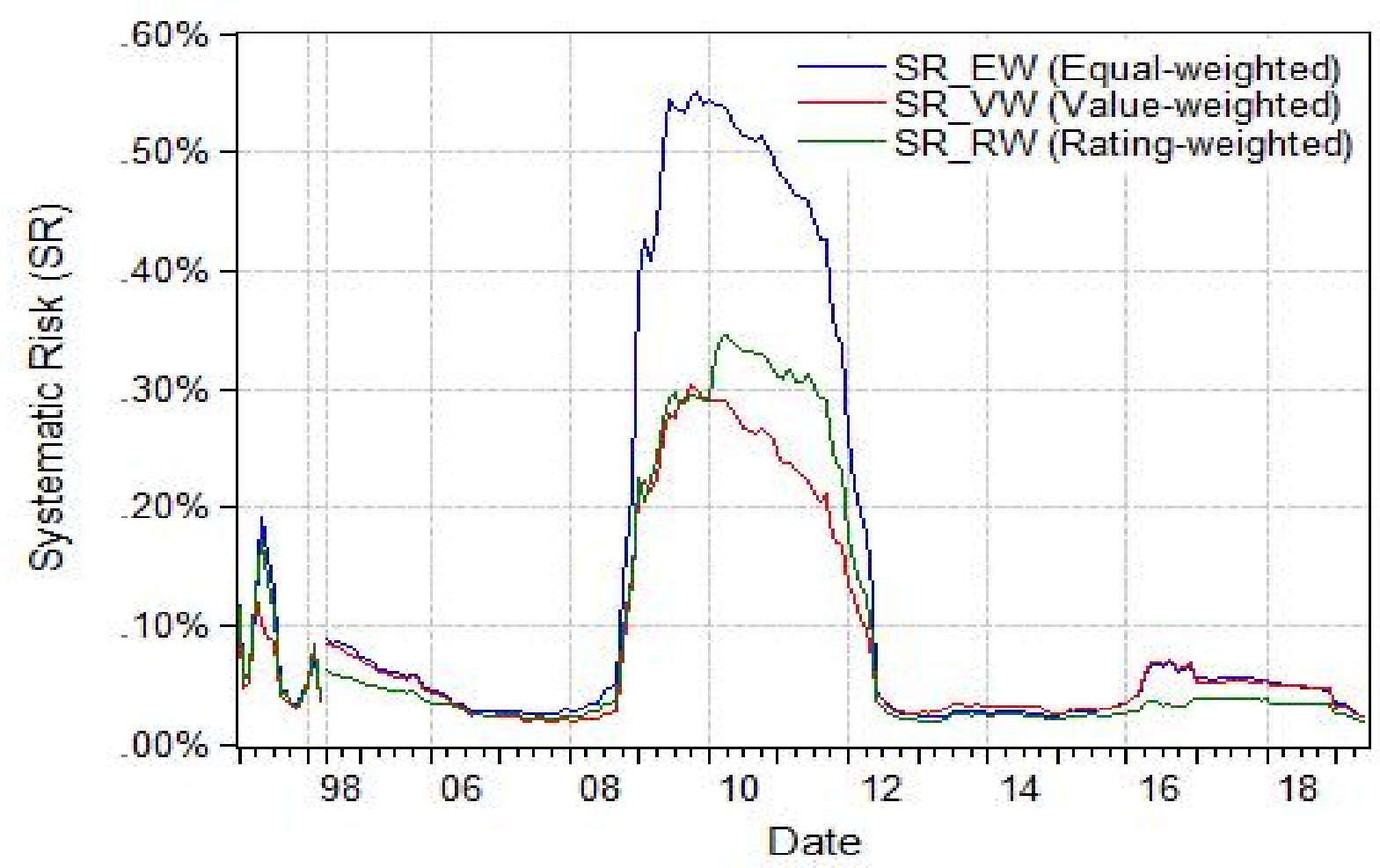

Fig.1. Systematic risk (SR) over time. This figure plots the monthly time-series of aggregate SR for the period from January 1997 to June 2019 for the equal-, value-, and rating-weighted average of bond systematic risk. 


\section{Table 1: The Intertemporal Risk-Return Tradeoff in the Corporate Bond Market}

This table reports the significance of an intertemporal relation between expected return and risk of corporate bond market returns,

$$
R_{m, t+1}=\alpha+\beta \cdot \sigma_{m, t}^{2}+\epsilon_{m, t+1}
$$

and

$$
R_{m, t+1}=\alpha+\beta \cdot \sigma_{m, t}^{2}+\lambda \cdot X_{t}+\epsilon_{m, t+1} .
$$

where $R_{m, t+1}$ is the monthly excess return of the bond market in month $t+1$ and $\sigma_{m, t}^{2}$ is the onemonth lagged realized variance of the bond market, proxying for the time- $t$ expected conditional variance of excess bond market returns at time $t+1$. The table presents results from the monthly predictive regressions with the value-weighted corporate bond market index ( $\mathrm{VW}^{\text {bond }}$ ) and the Merrill Lynch bond index $\left(\mathrm{MRL}^{\text {bond }}\right)$. Panel A reports the univariate regression results. Panel B reports the multivariate regression results after controlling for macroeconomic variables including the log earningsto-price ratio (EP), the log dividend-to-price ratio (DP), the book-to-market ratio (BM), the difference between long-term return on government bonds and the one-month Treasury-bill (TERM), and the difference between the return on a market portfolio of long-term corporate bonds and the long-term government bond return (DEF). The sample period is from January 1997 to June 2019. $t$-statistics are reported in parentheses and ${ }^{*},{ }^{* *}$, and ${ }^{* * *}$ indicate the significance at the $10 \%, 5 \%$, and $1 \%$ level, respectively.

Panel A: Univariate regressions

\begin{tabular}{cccc}
\hline Dependent variable & Intercept & $\sigma_{m}^{2}$ & Adj. $R^{2}(\%)$ \\
\hline VW $_{t+1}^{\text {bond }}$ & -0.10 & $21.75^{* *}$ & 6.49 \\
& $(-0.53)$ & $(2.55)$ & \\
MRL $_{t+1}^{\text {bond }}$ & -0.08 & $17.53^{* *}$ & 3.50 \\
& $(-0.38)$ & $(2.22)$ & \\
\hline
\end{tabular}

Panel B: Multivariate regressions

\begin{tabular}{ccccccccc}
\hline Dependent variable & Intercept & $\sigma_{m}^{2}$ & $\mathrm{EP}$ & $\mathrm{DP}$ & $\mathrm{BM}$ & $\mathrm{DEF}$ & TERM & Adj. $R^{2}(\%)$ \\
\hline $\mathrm{VW}_{t+1}^{\text {bond }}$ & 3.22 & $10.62^{* * *}$ & $-0.63^{*}$ & 1.39 & 1.67 & $0.12^{* *}$ & $0.14^{*}$ & 19.48 \\
& $(0.64)$ & $(2.86)$ & $(-1.93)$ & $(1.50)$ & $(0.63)$ & $(2.15)$ & $(1.71)$ & \\
$\mathrm{MRL}_{t+1}^{\text {bond }}$ & -0.55 & $11.18^{* * *}$ & $-0.51^{* *}$ & 0.34 & 1.11 & $0.08^{* *}$ & $0.16^{*}$ & 7.64 \\
& $(-0.13)$ & $(2.71)$ & $(-2.08)$ & $(0.42)$ & $(0.52)$ & $(2.14)$ & $(1.69)$ & \\
\hline
\end{tabular}


Table 2: Economic Significance of the Intertemporal Risk-Return Tradeoff in the Bond Market

This table reports the portfolio performance measures for a mean-variance investor with a risk aversion coefficient $(\gamma)$ of 10,15 and 20, who allocates monthly between corporate bonds and risk-free bills using the out-of-sample forecasts of the excess bond market returns based on the bond market variance $\left(\sigma_{m}^{2}\right)$. CER gain (\%) is the annualized certainty equivalent return gain for the investor, defined as the annual portfolio management fee that an investor would be willing to pay to have access to the predictive regression forecast instead of the historical average forecast. The portfolio weights are estimated recursively using the data available at the forecast formation time $t .{ }^{*},{ }^{* *}$, and ${ }^{* * *}$ indicate significance at the $10 \%, 5 \%$, and $1 \%$ level, respectively.

Panel A: CER gain (\%) from investing on $\mathrm{VW}^{\text {bond }}$

\begin{tabular}{lllllll}
\hline & $\sigma_{m}^{2}$ & EP & DP & BM & DEF & TERM \\
\cline { 2 - 6 }$\gamma=10$ & $3.64^{* * *}$ & -2.23 & -0.22 & -4.38 & -2.70 & $1.68^{* *}$ \\
$\gamma=15$ & $4.34^{* * *}$ & -1.19 & -0.15 & -2.61 & -1.50 & $1.94^{* *}$ \\
$\gamma=20$ & $5.04^{* * *}$ & -0.67 & -0.11 & -1.72 & -0.90 & $2.47^{* * *}$ \\
\hline
\end{tabular}

Panel B: CER gain (\%) from investing on $\mathrm{MRL}^{\text {bond }}$

\begin{tabular}{lcccccc}
\hline & $\sigma_{m}^{2}$ & EP & DP & BM & DEF & TERM \\
\cline { 2 - 7 }$\gamma=10$ & $2.69^{* * *}$ & -0.17 & -1.00 & 0.21 & -3.84 & $0.67^{*}$ \\
$\gamma=15$ & $3.24^{* * *}$ & 0.17 & -0.38 & $0.43^{*}$ & -2.26 & $0.74^{*}$ \\
$\gamma=20$ & $3.85^{* * *}$ & 0.34 & -0.07 & $0.54^{*}$ & -1.48 & $0.77^{*}$ \\
\hline
\end{tabular}




\section{Table 3: The Intertemporal Risk-Return Tradeoff in the Equity Market}

This table reports the significance of an intertemporal relation between expected return and risk of equity market returns,

$$
R_{m, t+1}=\alpha+\beta \cdot \sigma_{m, t}^{2}+\epsilon_{m, t+1},
$$

and

$$
R_{m, t+1}=\alpha+\beta \cdot \sigma_{m, t}^{2}+\lambda \cdot X_{t}+\epsilon_{m, t+1} .
$$

where $R_{m, t+1}$ is the monthly excess return of the equity market (i.e., the value-weighted CRSP index) in month $t+1$ and $\sigma_{m, t}^{2}$ is the one-month lagged realized variance of the equity market. The table presents results from the monthly predictive regressions for the common sample period January 1997 to June 2019 and an extended sample period from July 1926 to June 2019. Panel A reports the univariate regression results. Panel $\mathrm{B}$ reports the multivariate regression results after controlling for macroeconomic variables including the log earnings-to-price ratio (EP), the log dividend-to-price ratio (DP), the book-to-market ratio $(\mathrm{BM})$, the difference between long-term return on government bonds and the one-month Treasury-bill (TERM), and the difference between the return on a market portfolio of long-term corporate bonds and the long-term government bond return (DEF). $t$-statistics are reported in parentheses and ${ }^{*},{ }^{* *}$, and ${ }^{* * *}$ indicate the significance at the $10 \%, 5 \%$, and $1 \%$ level,

\begin{tabular}{|c|c|c|c|}
\hline Sample period & Intercept & $\sigma_{m}^{2}$ & Adj. $R^{2}(\%)$ \\
\hline January 1997 - June 2019 & $\begin{array}{c}0.21 \\
(0.38)\end{array}$ & $\begin{array}{c}1.91 \\
(0.76)\end{array}$ & -0.14 \\
\hline July 1926 - June 2019 & $\begin{array}{l}0.47^{* *} \\
(2.26)\end{array}$ & $\begin{array}{c}0.53 \\
(0.79)\end{array}$ & 0.05 \\
\hline
\end{tabular}
respectively.

\begin{tabular}{|c|c|c|c|c|c|c|c|c|}
\hline Sample period & Intercept & $\sigma_{m}^{2}$ & $\mathrm{EP}$ & DP & $\mathrm{BM}$ & DEF & TERM & Adj. $R^{2}(\%)$ \\
\hline January 1997 - June 2019 & $\begin{array}{c}36.57^{* *} \\
(2.33)\end{array}$ & $\begin{array}{c}4.27 \\
(1.34)\end{array}$ & $\begin{array}{c}2.14 \\
(1.55)\end{array}$ & $\begin{array}{l}6.55^{* *} \\
(2.24)\end{array}$ & $\begin{array}{l}-14.05 \\
(-1.65)\end{array}$ & $\begin{array}{c}0.15 \\
(0.94)\end{array}$ & $\begin{array}{c}0.40 \\
(1.28)\end{array}$ & 3.01 \\
\hline July 1926 - June 2019 & $\begin{array}{l}10.11^{*} \\
(1.87)\end{array}$ & $\begin{array}{c}-0.22 \\
(-0.12)\end{array}$ & $\begin{array}{c}0.76 \\
(0.67)\end{array}$ & $\begin{array}{c}1.63 \\
(1.35)\end{array}$ & $\begin{array}{l}-3.06 \\
(-1.48)\end{array}$ & $\begin{array}{c}0.23^{* * *} \\
(3.13)\end{array}$ & $\begin{array}{l}0.54^{* *} \\
(2.40)\end{array}$ & 2.89 \\
\hline
\end{tabular}

Panel B: Multivariate regressions 


\section{Table 4: Summary Statistics of the Cross-Sectional Variables}

Panel A reports the number of bond-month observations, the cross-sectional mean, median, standard deviation and percentiles for corporate bond monthly returns and bond characteristics including credit rating, time-to-maturity (Maturity, year), amount outstanding (Size, $\$$ billion), downside risk (5\% Value-at-Risk, VaR), illiquidity (ILLIQ), and systematic risk (SR). Ratings are in conventional numerical scores, where 1 refers to an AAA rating and 21 refers to a $\mathrm{C}$ rating. Higher numerical score means higher credit risk. Numerical ratings of 10 or below (BBB- or better) are considered investment grade. Downside risk is the 5\% Value-at-Risk (VaR) of corporate bond return, defined as the second lowest monthly return observation over the past 36 months. The original VaR measure is multiplied by -1 so that a higher VaR indicates higher downside risk. Bond illiquidity is computed as the autocovariance of the daily price changes within each month, multiplied by -1 . Systematic risk is defined as the difference between total and idiosyncratic variance using a 36-month rolling window. The factor model used to generate systematic risk is the 4-factor model of Bai, Bali, and Wen (2019) including the excess bond market return $\left(\mathrm{MKT}^{\text {Bond }}\right)$, the downside risk factor (DRF), the credit risk factor (CRF), and the liquidity risk factors (LRF) . Panel B reports the time-series average of the cross-sectional correlations. The sample period is from January 1997 to June 2019.

Panel A: Cross-sectional statistics over the sample period of January 1997 - June 2019

\begin{tabular}{|c|c|c|c|c|c|c|c|c|c|c|}
\hline & \multirow[b]{2}{*}{$\mathrm{N}$} & \multirow[b]{2}{*}{ Mean } & \multirow[b]{2}{*}{ Median } & \multirow[b]{2}{*}{$\mathrm{SD}$} & \multicolumn{6}{|c|}{ Percentiles } \\
\hline & & & & & 1 st & 5 th & 25 th & 75 th & 95 th & 99th \\
\hline Bond return $(\%)$ & $1,318,058$ & 0.77 & 0.57 & 3.62 & -8.16 & -3.61 & -0.56 & 1.86 & 5.61 & 12.18 \\
\hline Rating & $1,315,405$ & 8.09 & 7.54 & 3.64 & 1.53 & 2.64 & 5.57 & 9.99 & 15.12 & 17.94 \\
\hline Time-to-maturity (maturity, year) & $1,328,785$ & 10.13 & 7.07 & 9.13 & 1.32 & 1.93 & 4.20 & 13.39 & 27.24 & 34.15 \\
\hline Amount Out (size, \$billion) & $1,328,785$ & 0.45 & 0.31 & 0.48 & 0.02 & 0.04 & 0.14 & 0.58 & 1.35 & 2.39 \\
\hline Downside risk $(5 \% \mathrm{VaR})$ & 797,761 & 4.80 & 3.40 & 4.77 & 0.58 & 0.96 & 2.03 & 5.77 & 13.63 & 23.69 \\
\hline ILLIQ & 913,665 & 1.57 & 0.60 & 3.79 & -0.83 & -0.24 & 0.08 & 1.59 & 6.99 & 16.23 \\
\hline Systematic Risk (SR, \%) & 764,548 & 0.13 & 0.04 & 0.27 & 0.00 & 0.00 & 0.01 & 0.10 & 0.70 & 1.10 \\
\hline
\end{tabular}

Panel B: Average cross-sectional correlations

\begin{tabular}{|c|c|c|c|c|c|c|}
\hline & Rating & Maturity & Size & VaR & ILLIQ & $\mathrm{SR}$ \\
\hline Rating & 1 & -0.113 & -0.044 & 0.400 & 0.091 & 0.342 \\
\hline Maturity & & 1 & -0.046 & 0.176 & 0.096 & 0.124 \\
\hline Size & & & 1 & -0.074 & -0.145 & -0.083 \\
\hline VaR & & & & 1 & 0.228 & 0.623 \\
\hline ILLIQ & & & & & 1 & 0.184 \\
\hline $\mathrm{SR}$ & & & & & & 1 \\
\hline
\end{tabular}




\section{Table 5: Univariate Portfolios of Corporate Bonds Sorted by Systematic Risk}

Quintile portfolios are formed every month from January 1997 to June 2019 by sorting corporate bonds based on systematic risk (SR), defined as the difference between total and idiosyncratic variance from regression (14). The benchmark model used to generate systematic risk is BBW 4-factor model with the excess bond market return, the downside risk factor, the credit risk factor, and the liquidity risk factor. Quintile 1 is the portfolio with the lowest SR and Quintile 5 is the portfolio with the highest SR. The portfolios are value-weighted using amount outstanding as weights. Table reports the average SR, the next-month average excess return, the 5-factor alpha from stock market factors, the 5-factor alpha from bond market factors, the 10-factor alpha for each quintile. The last six columns report average portfolio characteristics including bond beta ( $\beta^{M K T}$ ), illiquidity (ILLIQ), downside risk (VaR), credit rating, time-to-maturity (years), and amount outstanding (size, in \$billion) for each quintile. The last row shows the differences in monthly average returns, the differences in alphas with respect to the factor models. The 5 -factor model with stock market factors includes the excess stock market return $\left(\mathrm{MKT}^{\text {Stock }}\right)$, the size factor (SMB), the book-to-market factor (HML), the momentum factor $\left(\mathrm{MOM}^{\text {Stock }}\right)$, and the stock liquidity factor $\left(\mathrm{LIQ}^{\text {Stock}}\right)$. The 5 -factor model with bond market factors includes the excess bond market return (MKT), the default factor (DEF), the term factor (TERM), the bond momentum factor $\left(\mathrm{MOM}^{\text {Bond }}\right)$, and the bond liquidity factor $\left(\mathrm{LIQ}^{\text {Bond }}\right)$. The 10-factor model combines the five stock and five bond market factors. Average excess returns and alphas are defined in monthly percentage terms. Newey-West adjusted $t$-statistics are given in parentheses. ${ }^{*},{ }^{* *}$, and ${ }^{* * *}$ indicate the significance at the $10 \%, 5 \%$, and $1 \%$ level, respectively.

\begin{tabular}{|c|c|c|c|c|c|c|c|c|c|c|c|}
\hline \multirow[t]{2}{*}{ Quintiles } & \multirow{2}{*}{$\begin{array}{c}\text { Average } \\
\text { SR }\end{array}$} & \multirow{2}{*}{$\begin{array}{c}\text { Average } \\
\text { return }\end{array}$} & \multirow{2}{*}{$\begin{array}{c}\text { 5-factor stock } \\
\text { alpha }\end{array}$} & \multirow{2}{*}{$\begin{array}{c}\text { 5-factor bond } \\
\text { alpha }\end{array}$} & \multirow{2}{*}{$\begin{array}{c}\text { 10-factor } \\
\text { alpha }\end{array}$} & \multicolumn{6}{|c|}{ Average portfolio characteristics } \\
\hline & & & & & & $\beta^{M K T}$ & ILLIQ & $\mathrm{VaR}$ & Rating & Maturity & Size \\
\hline Low & 0.01 & $\begin{array}{c}0.19 \\
(3.57)\end{array}$ & $\begin{array}{l}0.15 \\
(2.50)\end{array}$ & $\begin{array}{l}0.06 \\
(2.08)\end{array}$ & $\begin{array}{c}0.06 \\
(1.20)\end{array}$ & 0.34 & 0.53 & 1.84 & 7.33 & 4.48 & 0.51 \\
\hline 2 & 0.02 & $\begin{array}{c}0.35 \\
(4.10)\end{array}$ & $\begin{array}{c}0.28 \\
(3.12)\end{array}$ & $\begin{array}{c}0.14 \\
(3.37)\end{array}$ & $\begin{array}{c}0.13 \\
(2.65)\end{array}$ & 0.60 & 0.88 & 2.86 & 7.86 & 6.38 & 0.50 \\
\hline 3 & 0.04 & $\begin{array}{c}0.43 \\
(3.73)\end{array}$ & $\begin{array}{c}0.33 \\
(2.78)\end{array}$ & $\begin{array}{c}0.16 \\
(3.39)\end{array}$ & $\begin{array}{c}0.15 \\
(2.70)\end{array}$ & 0.86 & 1.16 & 3.84 & 8.05 & 8.75 & 0.53 \\
\hline 4 & 0.08 & $\begin{array}{c}0.56 \\
(3.80)\end{array}$ & $\begin{array}{c}0.40 \\
(3.03)\end{array}$ & $\begin{array}{c}0.29 \\
(4.74)\end{array}$ & $\begin{array}{c}0.23 \\
(3.10)\end{array}$ & 1.18 & 1.77 & 5.73 & 8.46 & 13.16 & 0.51 \\
\hline High & 0.51 & $\begin{array}{l}1.03 \\
(4.00)\end{array}$ & $\begin{array}{c}0.76 \\
(3.05)\end{array}$ & $\begin{array}{c}0.80 \\
(3.77)\end{array}$ & $\begin{array}{l}0.68 \\
(2.38)\end{array}$ & 1.93 & 3.11 & 11.93 & 10.90 & 14.51 & 0.47 \\
\hline High - Low & & $\begin{array}{c}0.85^{* * *} \\
(3.64)\end{array}$ & $\begin{array}{l}0.61^{* *} \\
(2.51)\end{array}$ & $\begin{array}{c}0.73^{* * *} \\
(3.25)\end{array}$ & $\begin{array}{l}0.62^{* *} \\
(2.46)\end{array}$ & & & & & & \\
\hline
\end{tabular}




\section{Table 6: Univariate Portfolios of Corporate Bonds Sorted by Idiosyncratic Risk}

Quintile portfolios are formed every month from January 1997 to June 2019 by sorting corporate bonds based on idiosyncratic risk (IR), defined as the residual variance from regression (14). The benchmark model used to generate idiosyncratic risk is BBW 4-factor model with the excess bond market return, the downside risk factor, the credit risk factor, and the liquidity risk factor. Quintile 1 is the portfolio with the lowest IR and Quintile 5 is the portfolio with the highest IR. The portfolios are value-weighted using amount outstanding as weights. Table reports the average IR, the next-month average excess return, the 5-factor alpha from stock market factors, the 5-factor alpha from bond market factors, the 10-factor alpha for each quintile. The last six columns report average portfolio characteristics including bond beta $\left(\beta^{M K T}\right)$, illiquidity (ILLIQ), downside risk (VaR), credit rating, timeto-maturity (years), and amount outstanding (size, in \$billion) for each quintile. The last row shows the differences in monthly average returns, the differences in alphas with respect to the factor models. The 5 -factor model with stock market factors includes the excess stock market return (MKT $\left.{ }^{\text {Stock }}\right)$, the size factor (SMB), the book-to-market factor (HML), the momentum factor $\left(\mathrm{MOM}^{\text {Stock}}\right)$, and the stock liquidity factor (LIQ $\left.{ }^{\text {Stock }}\right)$. The 5 -factor model with bond market factors includes the excess bond market return (MKT), the default factor (DEF), the term factor (TERM), the bond momentum factor $\left(\mathrm{MOM}^{\text {Bond }}\right)$, and the bond liquidity factor $\left(\mathrm{LIQ}^{\text {Bond }}\right)$. The 10-factor model combines the five stock and five bond market factors. Average excess returns and alphas are defined in monthly percentage terms. Newey-West adjusted $t$-statistics are given in parentheses. ${ }^{*},{ }^{* *}$, and ${ }^{* * *}$ indicate the significance at the $10 \%, 5 \%$, and $1 \%$ level, respectively.

\begin{tabular}{|c|c|c|c|c|c|c|c|c|c|c|c|}
\hline \multirow[t]{2}{*}{ Quintiles } & \multirow{2}{*}{$\begin{array}{c}\text { Average } \\
\text { IR }\end{array}$} & \multirow{2}{*}{$\begin{array}{l}\text { Average } \\
\text { return }\end{array}$} & \multirow{2}{*}{$\begin{array}{c}\text { 5-factor stock } \\
\text { alpha }\end{array}$} & \multirow{2}{*}{$\begin{array}{c}\text { 5-factor bond } \\
\text { alpha }\end{array}$} & \multirow{2}{*}{$\begin{array}{c}\text { 10-factor } \\
\text { alpha }\end{array}$} & \multicolumn{6}{|c|}{ Average portfolio characteristics } \\
\hline & & & & & & $\beta^{M K T}$ & ILLIQ & VaR5 & Rating & Maturity & Size \\
\hline Low & 0.01 & $\begin{array}{c}0.23 \\
(3.47)\end{array}$ & $\begin{array}{c}0.05 \\
(1.47)\end{array}$ & $\begin{array}{c}0.20 \\
(1.89)\end{array}$ & $\begin{array}{c}-0.06 \\
(-1.56)\end{array}$ & 0.60 & 0.31 & 1.71 & 6.57 & 4.17 & 0.76 \\
\hline 2 & 0.02 & $\begin{array}{c}0.37 \\
(3.93)\end{array}$ & $\begin{array}{c}0.13 \\
(3.46)\end{array}$ & $\begin{array}{c}0.31 \\
(3.12)\end{array}$ & $\begin{array}{c}0.13 \\
(3.35)\end{array}$ & 0.76 & 0.77 & 2.71 & 7.68 & 7.26 & 0.50 \\
\hline 3 & 0.05 & $\begin{array}{c}0.41 \\
(3.14)\end{array}$ & $\begin{array}{c}0.09 \\
(1.40)\end{array}$ & $\begin{array}{c}0.29 \\
(2.13)\end{array}$ & $\begin{array}{c}0.06 \\
(0.99)\end{array}$ & 0.96 & 1.36 & 3.91 & 8.00 & 11.19 & 0.47 \\
\hline 4 & 0.12 & $\begin{array}{c}0.48 \\
(3.08)\end{array}$ & $\begin{array}{c}0.23 \\
(3.13)\end{array}$ & $\begin{array}{c}0.31 \\
(2.07)\end{array}$ & $\begin{array}{c}0.09 \\
(1.20)\end{array}$ & 1.11 & 1.87 & 5.64 & 8.56 & 12.98 & 0.43 \\
\hline High & 0.72 & $\begin{array}{c}0.69 \\
(2.93)\end{array}$ & $\begin{array}{c}0.50 \\
(3.21)\end{array}$ & $\begin{array}{c}0.29 \\
(1.54)\end{array}$ & $\begin{array}{c}0.10 \\
(1.45)\end{array}$ & 1.49 & 3.25 & 12.27 & 11.89 & 11.68 & 0.36 \\
\hline High - Low & & $\begin{array}{c}0.45^{* *} \\
(2.14)\end{array}$ & $\begin{array}{c}0.44^{* *} \\
(2.73)\end{array}$ & $\begin{array}{c}0.10 \\
(0.58)\end{array}$ & $\begin{array}{c}0.17 \\
(1.16)\end{array}$ & & & & & & \\
\hline
\end{tabular}




\section{Table 7: Bivariate Portfolios of Corporate Bonds Sorted by Systematic Risk and Idiosyncratic Risk}

In Panel A, quintile portfolios are formed every month from January 1997 to June 2019 by first sorting corporate bonds based on their idiosyncratic risk. Then, within each IR portfolios, corporate bonds are sorted into subquintiles based on their systematic risk. Quintile SR,1 is the portfolio of corporate bonds with the lowest SR within each IR quintile portfolio, and Quintile SR,5 is the portfolio of corporate bonds with the highest SR with each IR quintile portfolio. Panel A reports the average SRs within each IR quintile as well as the next month average return of corporate bonds for each quintile. The last four rows present the differences in the monthly returns, the 5-factor stock alpha, the 5-factor bond alpha, and the 10-factor alpha between Quintile SR, 5 and Quintile SR,1. Average returns and alphas are defined in monthly percentage terms. Newey-West adjusted $t$-statistics are given in parentheses. ${ }^{*},{ }^{* *}$, and ${ }^{* * *}$ indicate significance at the $10 \%, 5 \%$, and $1 \%$ level, respectively. Panel B replicates the same procedure for quintile portfolios of corporate bonds sorted by IR after controlling for SR.

Panel A: Corporate bonds sorted by SR after controlling for IR

\begin{tabular}{ccc}
\hline SR quintiles after controlling for IR & $\begin{array}{c}\text { Avg SR in } \\
\text { each IR quintile }\end{array}$ & $\begin{array}{c}\text { Next month } \\
\text { avg returns }\end{array}$ \\
SR,1 & 0.02 & 0.44 \\
SR,2 & 0.06 & 0.50 \\
SR,3 & 0.10 & 0.53 \\
SR,4 & 0.17 & 0.70 \\
SR,1 return diff. & 0.31 & 1.21 \\
SR,5 - & & $0.77^{* * *}$ \\
SR,5 - SR,1 5-factor stock alpha diff. & & $(2.73)$ \\
& & $0.71^{* *}$ \\
SR,5 - SR,1 5-factor bond alpha diff. & & $(2.52)$ \\
& & $0.65^{* *}$ \\
SR,5 - SR,1 10-factor alpha diff. & & $(2.43)$
\end{tabular}

Panel B: Corporate bonds sorted by IR after controlling for SR

\begin{tabular}{ccc}
\hline IR quintiles after controlling for SR & $\begin{array}{c}\text { Avg IR in } \\
\text { each SR quintile }\end{array}$ & $\begin{array}{c}\text { Next month } \\
\text { avg returns }\end{array}$ \\
USR,1 & 0.04 & 0.32 \\
USR,2 & 0.08 & 0.33 \\
USR,3 & 0.14 & 0.36 \\
USR,4 & 0.22 & 0.38 \\
USR,5 & 0.44 & 0.43 \\
USR,5 - USR,1 return diff. & & 0.11 \\
& & $(0.78)$ \\
USR,5 - USR,1 5-factor stock alpha diff. & & -0.07 \\
& & $(-0.61)$ \\
USR,5 - USR,1 5-factor bond alpha diff. & & 0.17 \\
& & $(1.25)$ \\
USR,5 - USR,1 10-factor alpha diff. & & 0.02 \\
& & $(0.03)$ \\
\hline
\end{tabular}




\section{Table 8: Bond-level Fama-MacBeth Cross-Sectional Regressions}

This table reports the average intercept and slope coefficients from the Fama and MacBeth (1973) cross-sectional regressions of one-month-ahead corporate bond excess returns on systematic risk and idiosyncratic risk with and without control variables. Bond characteristics include credit rating, illiquidity, time-to-maturity and the natural logarithm of amount outstanding. Other control variables consist of the bond market beta $\left(\beta^{M K T}\right)$, the default beta $\left(\beta^{D E F}\right)$, the term beta $\left(\beta^{T E R M}\right)$, and bond return in previous month (REV). Fama-MacBeth regressions are run each month for the period from January 1997 to June 2019. Newey-West (1987) $t$-statistics are reported in parentheses. The last column reports the average adjusted $R^{2}$ values. Numbers in bold denote statistical significance at the $5 \%$ level or better.

\begin{tabular}{|c|c|c|c|c|c|c|c|c|c|c|c|c|}
\hline & Intercept & SR & IR & $\beta^{M K T}$ & $\beta^{D E F}$ & $\beta^{T E R M}$ & Rating & ILLIQ & Maturity & Size & REV & Adj. $R^{2}(\%)$ \\
\hline (1) & $\begin{array}{l}0.395 \\
(2.97)\end{array}$ & $\begin{array}{l}\mathbf{1 . 8 2 8} \\
(4.33)\end{array}$ & & & & & & & & & & 6.61 \\
\hline$(2)$ & $\begin{array}{l}0.361 \\
(3.03)\end{array}$ & & $\begin{array}{r}\mathbf{0 . 4 0 5} \\
(2.26)\end{array}$ & & & & & & & & & 4.99 \\
\hline (3) & $\begin{array}{l}0.328 \\
(2.63)\end{array}$ & $\begin{array}{l}\mathbf{1 . 3 1 9} \\
(4.31)\end{array}$ & $\begin{array}{l}-0.445 \\
(-0.45)\end{array}$ & & & & & & & & & 8.80 \\
\hline (4) & $\begin{array}{l}0.079 \\
(0.43)\end{array}$ & $\begin{array}{l}\mathbf{1 . 6 8 6} \\
(2.69)\end{array}$ & & $\begin{array}{l}0.054 \\
(0.85)\end{array}$ & $\begin{array}{l}-0.100 \\
(-1.04)\end{array}$ & $\begin{array}{c}0.073 \\
(-0.61)\end{array}$ & $\begin{array}{l}0.022 \\
(0.93)\end{array}$ & $\begin{array}{r}\mathbf{0 . 0 2 4} \\
(4.93)\end{array}$ & $\begin{array}{l}0.006 \\
(1.46)\end{array}$ & $\begin{array}{l}0.047 \\
(0.61)\end{array}$ & $\begin{array}{c}-\mathbf{0 . 0 8 3} \\
(-6.34)\end{array}$ & 20.83 \\
\hline$(5)$ & $\begin{array}{l}0.498 \\
(1.27)\end{array}$ & & $\begin{array}{c}0.185 \\
(0.72)\end{array}$ & $\begin{array}{c}0.027 \\
(0.41)\end{array}$ & $\begin{array}{l}-0.118 \\
(-1.34)\end{array}$ & $\begin{array}{l}0.129 \\
(1.11)\end{array}$ & $\begin{array}{l}0.013 \\
(0.58)\end{array}$ & $\begin{array}{r}\mathbf{0 . 0 1 9} \\
(4.06)\end{array}$ & $\begin{array}{l}-0.017 \\
(-0.72)\end{array}$ & $\begin{array}{l}0.023 \\
(0.41)\end{array}$ & $\begin{array}{r}\mathbf{- 0 . 1 1 1} \\
(-6.54)\end{array}$ & 21.15 \\
\hline (6) & $\begin{array}{r}-0.030 \\
(0.30)\end{array}$ & $\begin{array}{l}\mathbf{1 . 3 3 3} \\
(2.46)\end{array}$ & $\begin{array}{l}-0.374 \\
(-0.34)\end{array}$ & $\begin{array}{c}0.012 \\
(0.30)\end{array}$ & $\begin{array}{l}-0.117 \\
(-1.17)\end{array}$ & $\begin{array}{l}0.120 \\
(0.94)\end{array}$ & $\begin{array}{c}0.027 \\
(1.65)\end{array}$ & $\begin{array}{r}\mathbf{0 . 0 1 8} \\
(4.19)\end{array}$ & $\begin{array}{l}0.006 \\
(1.32)\end{array}$ & $\begin{array}{l}0.038 \\
(0.30)\end{array}$ & $\begin{array}{c}\mathbf{- 0 . 1 0 3} \\
(-7.76)\end{array}$ & 21.89 \\
\hline
\end{tabular}


Table 9: Predicting Aggregate Bond Market Returns and Bond Market Volatility Using Aggregate Systematic Risk

This table reports the time-series predictive power of aggregate systematic risk (SR) in predicting $\mathrm{N}$-month ahead aggregate bond market returns and bond market volatility for alternative horizons from month 1 to 12 . $\mathrm{VW}^{\text {bond }}$ is the excess return on the value-weighted bond market index. MKT $\mathrm{Mol}^{\mathrm{V}}$ is the aggregate monthly bond market variance defined in Eq. (4). The benchmark model used to generate systematic risk is the 4-factor model with the excess bond market return (MKT), the downside risk factor (DRF), the credit risk factor (CRF), and the liquidity risk factor (LRF). Aggregate systematic risk is the value-weighted average of the corporate bond systematic risk for each month. Control variables include the log earnings-to-price ratio (EP), the log dividend-to-price ratio (DP), the aggregate book-to-market ratio (BM), the term spread (TERM), the default spread (DEF), and the equity market variance (SVAR). The Newey-West adjusted $t$-statistics are given in parentheses.

Panel A: Dep. var $=\mathrm{VW}^{\text {bond }}$

\begin{tabular}{lccccccccc}
\hline Forecasting & Intercept & SR & EP & DP & BM & TERM & DEF & SVAR & Adj. $R^{2}(\%)$ \\
Horizon & & & & & & & & & \\
\hline $\mathrm{N}=1$ & -4.55 & $2.78^{* * *}$ & -0.41 & -0.69 & 1.59 & $0.09^{* *}$ & $0.20^{* *}$ & $0.49^{* *}$ & 13.10 \\
& $(-0.51)$ & $(2.84)$ & $(-0.99)$ & $(-0.37)$ & $(0.64)$ & $(2.32)$ & $(2.25)$ & $(2.53)$ & \\
$\mathrm{N}=2$ & -9.78 & $3.18^{* *}$ & -0.78 & -1.58 & 3.40 & -0.03 & -0.07 & $0.72^{* * *}$ & 11.35 \\
& $(-0.68)$ & $(2.50)$ & $(-1.12)$ & $(-0.55)$ & $(0.91)$ & $(-0.67)$ & $(-1.13)$ & $(2.95)$ & \\
$\mathrm{N}=3$ & 1.30 & $3.37^{* * *}$ & -0.45 & 0.79 & 1.56 & -0.05 & -0.06 & -0.00 & 5.63 \\
& $(0.11)$ & $(2.91)$ & $(-0.70)$ & $(0.36)$ & $(0.39)$ & $(-0.96)$ & $(-0.76)$ & $(-0.03)$ & \\
$\mathrm{N}=4$ & 9.17 & $2.80^{* * *}$ & -0.08 & 2.38 & 0.23 & -0.03 & 0.03 & -0.19 & 6.08 \\
& $(1.22)$ & $(2.98)$ & $(-0.21)$ & $(1.53)$ & $(0.08)$ & $(-1.07)$ & $(0.49)$ & $(-0.81)$ & \\
$\mathrm{N}=5$ & $12.14^{*}$ & $2.94^{* * *}$ & 0.11 & $2.97^{* *}$ & -0.19 & 0.05 & -0.03 & -0.13 & 7.34 \\
& $(1.77)$ & $(3.22)$ & $(0.33)$ & $(2.07)$ & $(-0.06)$ & $(1.07)$ & $(-0.65)$ & $(-0.78)$ & \\
$\mathrm{N}=6$ & 11.90 & $3.03^{* * *}$ & 0.40 & $2.57^{*}$ & -2.04 & -0.01 & 0.00 & $0.30^{* *}$ & 6.47 \\
& $(1.39)$ & $(3.47)$ & $(0.75)$ & $(1.69)$ & $(-0.51)$ & $(-0.20)$ & $(0.02)$ & $(2.07)$ & \\
$\mathrm{N}=7$ & 6.60 & $2.34^{* * *}$ & 0.22 & 1.45 & -0.86 & -0.03 & 0.02 & $0.54^{* *}$ & 6.59 \\
& $(0.69)$ & $(2.76)$ & $(0.44)$ & $(0.80)$ & $(-0.26)$ & $(-1.52)$ & $(0.37)$ & $(2.45)$ & \\
$\mathrm{N}=8$ & $14.15^{* *}$ & $2.72^{* * *}$ & $0.73^{* *}$ & $2.71^{* *}$ & $-4.34^{*}$ & -0.01 & -0.01 & $0.51^{* * *}$ & 7.68 \\
& $(2.28)$ & $(3.03)$ & $(2.30)$ & $(2.29)$ & $(-1.96)$ & $(-0.46)$ & $(-0.21)$ & $(4.34)$ & \\
$\mathrm{N}=9$ & $13.59^{* *}$ & $2.05^{* *}$ & 0.63 & $2.77^{* *}$ & -2.50 & -0.01 & 0.01 & $0.37^{* * *}$ & 4.79 \\
& $(2.04)$ & $(2.09)$ & $(1.57)$ & $(2.04)$ & $(-1.13)$ & $(-0.67)$ & $(0.20)$ & $(2.62)$ & \\
$\mathrm{N}=10$ & 11.76 & 1.75 & 0.30 & 2.69 & -0.52 & -0.05 & $-0.10^{*}$ & 0.16 & 4.62 \\
& $(1.07)$ & $(1.64)$ & $(0.51)$ & $(1.18)$ & $(-0.16)$ & $(-1.54)$ & $(-1.94)$ & $(0.75)$ & \\
$\mathrm{N}=11$ & 7.27 & 1.42 & -0.14 & 1.99 & 1.03 & -0.02 & $-0.14^{*}$ & -0.05 & 3.97 \\
& $(0.66)$ & $(1.23)$ & $(-0.23)$ & $(0.90)$ & $(0.29)$ & $(-0.40)$ & $(-1.93)$ & $(-0.27)$ & \\
$\mathrm{N}=12$ & 7.31 & 1.47 & -0.13 & 1.89 & -0.27 & -0.03 & $-0.10^{* *}$ & -0.12 & 0.86 \\
& $(0.75)$ & $(1.18)$ & $(-0.25)$ & $(0.98)$ & $(-0.06)$ & $(-1.32)$ & $(-2.31)$ & $(-0.80)$ & \\
\hline & & & & & & & & & \\
& & & & & & & & \\
& & & & & & & & &
\end{tabular}


Table 9. (Continued)

Panel B: Dep. var $=\mathrm{MKT}^{\text {Vol }}$

\begin{tabular}{|c|c|c|c|c|c|c|c|c|c|}
\hline $\begin{array}{l}\text { Forecasting } \\
\text { Horizon }\end{array}$ & Intercept & SR & $\mathrm{EP}$ & DP & $\mathrm{BM}$ & TERM & DEF & SVAR & Adj. $R^{2}(\%)$ \\
\hline $\mathrm{N}=1$ & $\begin{array}{c}9.76 \\
(0.75)\end{array}$ & $\begin{array}{c}1.80^{* * *} \\
(2.77)\end{array}$ & $\begin{array}{c}-0.37 \\
(-0.79)\end{array}$ & $\begin{array}{c}5.52^{* * *} \\
(3.55)\end{array}$ & $\begin{array}{c}-2.05 \\
(-0.81)\end{array}$ & $\begin{array}{l}-0.05 \\
(-0.97)\end{array}$ & $\begin{array}{l}-0.18 \\
(-1.27)\end{array}$ & $\begin{array}{c}0.86^{* * *} \\
(2.68)\end{array}$ & 30.24 \\
\hline $\mathrm{N}=2$ & $\begin{array}{l}13.92 \\
(0.78)\end{array}$ & $\begin{array}{c}1.59^{* *} \\
(2.21)\end{array}$ & $\begin{array}{c}0.09 \\
(0.17)\end{array}$ & $\begin{array}{c}5.85^{* * *} \\
(3.27)\end{array}$ & $\begin{array}{l}-4.82 \\
(-1.54)\end{array}$ & $\begin{array}{c}-0.03 \\
(-0.72)\end{array}$ & $\begin{array}{c}-0.02 \\
(-0.41)\end{array}$ & $\begin{array}{l}0.79^{*} \\
(1.93)\end{array}$ & 20.64 \\
\hline $\mathrm{N}=3$ & $\begin{array}{l}20.02 \\
(1.04)\end{array}$ & $\begin{array}{l}1.45^{* *} \\
(2.11)\end{array}$ & $\begin{array}{c}0.44 \\
(0.92)\end{array}$ & $\begin{array}{c}6.51^{* * *} \\
(3.56)\end{array}$ & $\begin{array}{c}-5.94^{* *} \\
(-2.00)\end{array}$ & $\begin{array}{c}0.04 \\
(0.92)\end{array}$ & $\begin{array}{l}-0.05 \\
(-0.81)\end{array}$ & $\begin{array}{c}0.65 \\
(1.62)\end{array}$ & 19.94 \\
\hline $\mathrm{N}=4$ & $\begin{array}{l}18.55 \\
(1.08)\end{array}$ & $\begin{array}{l}1.55^{* *} \\
(2.38)\end{array}$ & $\begin{array}{c}0.55 \\
(1.36)\end{array}$ & $\begin{array}{c}6.26^{* * *} \\
(3.77)\end{array}$ & $\begin{array}{c}-6.10^{* *} \\
(-2.17)\end{array}$ & $\begin{array}{c}-0.02 \\
(-0.42)\end{array}$ & $\begin{array}{c}-0.17^{* * *} \\
(-3.01)\end{array}$ & $\begin{array}{l}0.70^{* *} \\
(2.02)\end{array}$ & 19.09 \\
\hline $\mathrm{N}=5$ & $\begin{array}{l}20.36 \\
(1.21)\end{array}$ & $\begin{array}{c}1.43^{* *} \\
(2.03)\end{array}$ & $\begin{array}{c}1.03^{* *} \\
(2.00)\end{array}$ & $\begin{array}{c}6.57^{* * *} \\
(3.81)\end{array}$ & $\begin{array}{c}-8.32^{* *} \\
(-2.22)\end{array}$ & $\begin{array}{c}-0.07 \\
(-1.52)\end{array}$ & $\begin{array}{l}-0.05 \\
(-0.53)\end{array}$ & $\begin{array}{c}0.79^{* * *} \\
(3.32)\end{array}$ & 11.93 \\
\hline $\mathrm{N}=6$ & $\begin{array}{l}29.67 \\
(1.36)\end{array}$ & $\begin{array}{l}1.38^{*} \\
(1.94)\end{array}$ & $\begin{array}{c}1.56^{* * *} \\
(2.65)\end{array}$ & $\begin{array}{c}7.36^{* * *} \\
(3.69)\end{array}$ & $\begin{array}{c}-11.82^{* * *} \\
(-2.73)\end{array}$ & $\begin{array}{c}-0.03 \\
(-0.69)\end{array}$ & $\begin{array}{l}-0.00 \\
(-0.01)\end{array}$ & $\begin{array}{c}0.57 \\
(1.47)\end{array}$ & 11.24 \\
\hline $\mathrm{N}=7$ & $\begin{array}{l}29.50 \\
(1.21)\end{array}$ & $\begin{array}{l}1.27^{*} \\
(1.76)\end{array}$ & $\begin{array}{c}1.71^{* * *} \\
(2.98)\end{array}$ & $\begin{array}{c}7.34^{* * *} \\
(3.58)\end{array}$ & $\begin{array}{c}-13.00^{* * *} \\
(-3.14)\end{array}$ & $\begin{array}{c}0.02 \\
(0.57)\end{array}$ & $\begin{array}{l}-0.02 \\
(-0.25)\end{array}$ & $\begin{array}{l}0.62^{*} \\
(1.71)\end{array}$ & 10.99 \\
\hline $\mathrm{N}=8$ & $\begin{array}{l}23.77 \\
(1.03)\end{array}$ & $\begin{array}{c}1.21 \\
(1.64)\end{array}$ & $\begin{array}{c}1.65^{* * *} \\
(2.89)\end{array}$ & $\begin{array}{c}6.57^{* * *} \\
(3.31)\end{array}$ & $\begin{array}{c}-12.35^{* * * *} \\
(-3.13)\end{array}$ & $\begin{array}{c}-0.03 \\
(-0.83)\end{array}$ & $\begin{array}{c}-0.02 \\
(-0.45)\end{array}$ & $\begin{array}{c}0.76^{* * *} \\
(2.63)\end{array}$ & 7.62 \\
\hline $\mathrm{N}=9$ & $\begin{array}{l}18.54 \\
(1.05)\end{array}$ & $\begin{array}{l}1.28^{*} \\
(1.84)\end{array}$ & $\begin{array}{c}1.35^{* * *} \\
(2.90)\end{array}$ & $\begin{array}{c}5.26^{* * *} \\
(3.47)\end{array}$ & $\begin{array}{c}-12.61^{* * *} \\
(-3.25)\end{array}$ & $\begin{array}{c}-0.09 * * * \\
(-2.69)\end{array}$ & $\begin{array}{l}-0.10^{*} \\
(-1.68)\end{array}$ & $\begin{array}{c}0.71^{* * *} \\
(3.32)\end{array}$ & 7.99 \\
\hline $\mathrm{N}=10$ & $\begin{array}{l}20.65 \\
(1.51)\end{array}$ & $\begin{array}{l}1.19^{*} \\
(1.76)\end{array}$ & $\begin{array}{c}1.23^{* * *} \\
(2.84)\end{array}$ & $\begin{array}{c}4.28^{* * *} \\
(3.46)\end{array}$ & $\begin{array}{c}-14.45^{* * *} \\
(-3.65)\end{array}$ & $\begin{array}{c}-0.02 \\
(-0.47)\end{array}$ & $\begin{array}{c}-0.04 \\
(-0.53)\end{array}$ & $\begin{array}{c}0.36 \\
(1.20)\end{array}$ & 6.46 \\
\hline $\mathrm{N}=11$ & $\begin{array}{l}21.82 \\
(1.55)\end{array}$ & $\begin{array}{l}1.22^{*} \\
(1.81)\end{array}$ & $\begin{array}{c}1.24^{* * *} \\
(2.69)\end{array}$ & $\begin{array}{c}3.90^{* * *} \\
(2.90)\end{array}$ & $\begin{array}{c}-15.78^{* * *} \\
(-3.84)\end{array}$ & $\begin{array}{c}0.02 \\
(0.52)\end{array}$ & $\begin{array}{c}-0.03 \\
(-0.41)\end{array}$ & $\begin{array}{c}0.23 \\
(0.67)\end{array}$ & 7.33 \\
\hline $\mathrm{N}=12$ & $\begin{array}{l}20.18 \\
(1.48)\end{array}$ & $\begin{array}{c}1.14 \\
(1.65)\end{array}$ & $\begin{array}{c}1.24^{* *} \\
(2.40)\end{array}$ & $\begin{array}{c}3.56^{* *} \\
(2.51)\end{array}$ & $\begin{array}{c}-16.17^{* * *} \\
(-3.40)\end{array}$ & $\begin{array}{c}0.00 \\
(0.02)\end{array}$ & $\begin{array}{c}0.02 \\
(0.31)\end{array}$ & $\begin{array}{c}0.26 \\
(0.86)\end{array}$ & 6.50 \\
\hline
\end{tabular}




\section{Table 10: Does Aggregate Idiosyncratic Risk Predict Bond Market Returns and Volatility?}

This table reports the time-series predictive power of aggregate idiosyncratic risk (IR) in predicting $\mathrm{N}$-month ahead aggregate bond market returns and bond market volatility for alternative horizons from month 1 to 12 . $\mathrm{VW}^{\text {bond }}$ is the excess return on the value-weighted bond market index. MKT $\mathrm{Mol}^{\mathrm{V}}$ is the aggregate monthly bond market variance defined in Eq. (4). The benchmark model used to generate idiosyncratic risk is the 4-factor model with the excess bond market return (MKT), the downside risk factor (DRF), the credit risk factor (CRF), and the liquidity risk factor (LRF). Aggregate idiosyncratic risk is the value-weighted average of the corporate bond idiosyncratic risk for each month. Control variables include the log earnings-to-price ratio (EP), the log dividend-to-price ratio (DP), the aggregate book-to-market ratio (BM), the term spread (TERM), the default spread (DEF), and the equity market variance (SVAR). The Newey-West adjusted $t$-statistics are given in parentheses.

Panel A: Dep. var $=\mathrm{VW}^{\text {bond }}$

\begin{tabular}{|c|c|c|c|c|c|c|c|c|c|}
\hline $\begin{array}{l}\text { Forecasting } \\
\text { Horizon }\end{array}$ & Intercept & IR & EP & $\mathrm{DP}$ & $\mathrm{BM}$ & TERM & $\mathrm{DEF}$ & SVAR & $\operatorname{Adj} . R^{2}(\%)$ \\
\hline $\mathrm{N}=1$ & $\begin{array}{c}-0.29 \\
(-0.55)\end{array}$ & $\begin{array}{c}1.30 \\
(1.20)\end{array}$ & $\begin{array}{c}-0.33 \\
(-0.18)\end{array}$ & $\begin{array}{c}-0.38^{* *} \\
(-2.03)\end{array}$ & $\begin{array}{c}2.14 \\
(1.07)\end{array}$ & $\begin{array}{c}0.16^{* * *} \\
(2.81)\end{array}$ & $\begin{array}{c}0.19^{* *} \\
(2.14)\end{array}$ & $\begin{array}{c}0.21 \\
(0.71)\end{array}$ & 21.87 \\
\hline $\mathrm{N}=2$ & $\begin{array}{c}-0.95 \\
(-1.53)\end{array}$ & $\begin{array}{c}1.10 \\
(1.13)\end{array}$ & $\begin{array}{c}1.61 \\
-0.67\end{array}$ & $\begin{array}{l}-0.30 \\
(-1.46)\end{array}$ & $\begin{array}{c}3.83 \\
(1.53)\end{array}$ & $\begin{array}{c}-0.03 \\
(-0.59)\end{array}$ & $\begin{array}{c}-0.05 \\
(-0.59)\end{array}$ & $\begin{array}{c}0.89^{* * *} \\
(2.96)\end{array}$ & 20.56 \\
\hline $\mathrm{N}=3$ & $\begin{array}{c}-0.78 \\
(-1.34)\end{array}$ & $\begin{array}{c}1.16 \\
(1.11)\end{array}$ & $\begin{array}{c}-0.52 \\
(-0.40)\end{array}$ & $\begin{array}{c}-0.45^{* *} \\
(-2.41)\end{array}$ & $\begin{array}{l}4.38^{*} \\
(1.89)\end{array}$ & $\begin{array}{l}-0.09^{*} \\
(-1.73)\end{array}$ & $\begin{array}{c}-0.09 \\
(-1.00)\end{array}$ & $\begin{array}{c}0.21 \\
(0.66)\end{array}$ & 12.41 \\
\hline $\mathrm{N}=4$ & $\begin{array}{c}-0.33 \\
(-0.54)\end{array}$ & $\begin{array}{c}1.33 \\
(1.36)\end{array}$ & $\begin{array}{l}-3.51^{*} \\
(-1.81)\end{array}$ & $\begin{array}{c}-0.51^{* * *} \\
(-3.03)\end{array}$ & $\begin{array}{c}3.27 \\
(1.57)\end{array}$ & $\begin{array}{c}0.00 \\
(-0.10)\end{array}$ & $\begin{array}{c}0.03 \\
(0.46)\end{array}$ & $\begin{array}{l}-0.25 \\
(-0.54)\end{array}$ & 10.80 \\
\hline $\mathrm{N}=5$ & $\begin{array}{l}-0.53 \\
(-0.73)\end{array}$ & $\begin{array}{c}0.84 \\
(0.89)\end{array}$ & $\begin{array}{l}-2.38 \\
(-1.58)\end{array}$ & $\begin{array}{c}-0.44^{* * *} \\
(-2.75)\end{array}$ & $\begin{array}{c}3.39 \\
(1.32)\end{array}$ & $\begin{array}{c}0.08^{* *} \\
(1.98)\end{array}$ & $\begin{array}{c}0.04 \\
(0.49)\end{array}$ & $\begin{array}{c}0.17 \\
(0.75)\end{array}$ & 14.06 \\
\hline $\mathrm{N}=6$ & $\begin{array}{l}-0.45 \\
(-0.64)\end{array}$ & $\begin{array}{c}0.58 \\
(0.61)\end{array}$ & $\begin{array}{c}-1.15 \\
(-0.98)\end{array}$ & $\begin{array}{c}-0.32^{* *} \\
(-1.97)\end{array}$ & $\begin{array}{c}2.64 \\
(1.04)\end{array}$ & $\begin{array}{c}-0.01 \\
(-0.38)\end{array}$ & $\begin{array}{c}0.00 \\
(0.01)\end{array}$ & $\begin{array}{c}0.74^{* * *} \\
(4.83)\end{array}$ & 16.69 \\
\hline $\mathrm{N}=7$ & $\begin{array}{c}-0.47 \\
(-0.73)\end{array}$ & $\begin{array}{c}0.54 \\
(0.58)\end{array}$ & $\begin{array}{l}-2.00 \\
(-1.35)\end{array}$ & $\begin{array}{c}-0.41^{* * *} \\
(-3.15)\end{array}$ & $\begin{array}{c}3.11 \\
(1.49)\end{array}$ & $\begin{array}{c}-0.05 \\
(-1.48)\end{array}$ & $\begin{array}{c}-0.07 \\
(-0.99)\end{array}$ & $\begin{array}{c}0.49^{* * *} \\
(2.72)\end{array}$ & 14.69 \\
\hline $\mathrm{N}=8$ & $\begin{array}{c}0.18 \\
-0.25\end{array}$ & $\begin{array}{c}0.64 \\
(0.65)\end{array}$ & $\begin{array}{c}0.17 \\
-0.17\end{array}$ & $\begin{array}{c}-0.14 \\
(-0.89)\end{array}$ & $\begin{array}{c}0.23 \\
(0.09)\end{array}$ & $\begin{array}{c}-0.02 \\
(-0.76)\end{array}$ & $\begin{array}{c}0.00 \\
(-0.06)\end{array}$ & $\begin{array}{c}0.72^{* *} \\
(2.54)\end{array}$ & 7.70 \\
\hline $\mathrm{N}=9$ & $\begin{array}{c}-0.42 \\
(-0.56)\end{array}$ & $\begin{array}{c}-0.26 \\
(-0.26)\end{array}$ & $\begin{array}{c}1.08 \\
-0.93\end{array}$ & $\begin{array}{l}-0.23 \\
(-1.57)\end{array}$ & $\begin{array}{c}2.75 \\
(1.07)\end{array}$ & $\begin{array}{c}0.01 \\
(0.32)\end{array}$ & $\begin{array}{c}0.01 \\
(0.12)\end{array}$ & $\begin{array}{c}0.65^{* * *} \\
(4.85)\end{array}$ & 6.75 \\
\hline $\mathrm{N}=10$ & $\begin{array}{c}-0.66 \\
(-0.82)\end{array}$ & $\begin{array}{c}-0.19 \\
(-0.19)\end{array}$ & $\begin{array}{c}0.38 \\
-0.35\end{array}$ & $\begin{array}{c}-0.33^{* *} \\
(-2.22)\end{array}$ & $\begin{array}{c}3.98 \\
(1.42)\end{array}$ & $\begin{array}{l}-0.05^{*} \\
(-1.85)\end{array}$ & $\begin{array}{c}-0.12^{* *} \\
(-2.26)\end{array}$ & $\begin{array}{c}0.41^{* *} \\
(2.21)\end{array}$ & 7.09 \\
\hline $\mathrm{N}=11$ & $\begin{array}{c}-0.18 \\
(-0.19)\end{array}$ & $\begin{array}{c}0.19 \\
(0.20)\end{array}$ & $\begin{array}{c}0.10 \\
-0.08\end{array}$ & $\begin{array}{l}-0.26^{*} \\
(-1.81)\end{array}$ & $\begin{array}{c}2.12 \\
(0.70)\end{array}$ & $\begin{array}{c}-0.04 \\
(-1.16)\end{array}$ & $\begin{array}{c}-0.12^{* *} \\
(-2.29)\end{array}$ & $\begin{array}{c}0.32^{* * *} \\
(2.67)\end{array}$ & 3.96 \\
\hline $\mathrm{N}=12$ & $\begin{array}{c}0.81 \\
(0.71)\end{array}$ & $\begin{array}{c}1.26 \\
(1.32)\end{array}$ & $\begin{array}{l}-1.92 \\
(-1.37)\end{array}$ & $\begin{array}{c}-0.14 \\
(-0.89)\end{array}$ & $\begin{array}{l}-1.56 \\
(-0.40)\end{array}$ & $\begin{array}{c}-0.04 \\
(-1.58)\end{array}$ & $\begin{array}{c}-0.07 \\
(-1.12)\end{array}$ & $\begin{array}{c}0.14 \\
(0.83)\end{array}$ & 0.62 \\
\hline
\end{tabular}


Table 10. (Continued)

Panel B: Dep. var $=\mathrm{MKT}^{\text {Vol }}$

\begin{tabular}{|c|c|c|c|c|c|c|c|c|c|}
\hline $\begin{array}{l}\text { Forecasting } \\
\text { Horizon }\end{array}$ & Intercept & IR & $\mathrm{EP}$ & DP & $\mathrm{BM}$ & TERM & DEF & SVAR & $\operatorname{Adj} . R^{2}(\%)$ \\
\hline $\mathrm{N}=1$ & $\begin{array}{l}11.60 \\
(0.85)\end{array}$ & $\begin{array}{c}2.20 \\
(1.41)\end{array}$ & $\begin{array}{c}-0.65 \\
(-1.23)\end{array}$ & $\begin{array}{c}3.06 \\
(1.10)\end{array}$ & $\begin{array}{l}-0.66 \\
(-0.14)\end{array}$ & $\begin{array}{c}-0.07^{* *} \\
(-2.06)\end{array}$ & $\begin{array}{c}-0.14 \\
(-1.17)\end{array}$ & $\begin{array}{c}0.86^{* * *} \\
(2.61)\end{array}$ & 34.46 \\
\hline $\mathrm{N}=2$ & $\begin{array}{l}15.44 \\
(0.87)\end{array}$ & $\begin{array}{c}1.84 \\
(1.33)\end{array}$ & $\begin{array}{l}-0.21 \\
(-0.34)\end{array}$ & $\begin{array}{c}3.47 \\
(0.96)\end{array}$ & $\begin{array}{l}-3.41 \\
(-0.61)\end{array}$ & $\begin{array}{c}-0.04^{* *} \\
(-2.11)\end{array}$ & $\begin{array}{c}0.01 \\
(0.28)\end{array}$ & $\begin{array}{l}0.80^{*} \\
(1.89)\end{array}$ & 23.96 \\
\hline $\mathrm{N}=3$ & $\begin{array}{c}21.7 \\
(1.12)\end{array}$ & $\begin{array}{c}1.81 \\
(1.35)\end{array}$ & $\begin{array}{c}0.22 \\
(0.30)\end{array}$ & $\begin{array}{c}4.61 \\
(1.18)\end{array}$ & $\begin{array}{l}-4.99 \\
(-0.84)\end{array}$ & $\begin{array}{c}0.03 \\
(0.99)\end{array}$ & $\begin{array}{l}-0.02 \\
(-0.39)\end{array}$ & $\begin{array}{c}0.65 \\
(1.59)\end{array}$ & 22.10 \\
\hline $\mathrm{N}=4$ & $\begin{array}{l}20.42 \\
(1.20)\end{array}$ & $\begin{array}{l}1.96^{*} \\
(1.73)\end{array}$ & $\begin{array}{c}0.30 \\
(0.48)\end{array}$ & $\begin{array}{c}4.22 \\
(1.21)\end{array}$ & $\begin{array}{l}-5.14 \\
(-0.94)\end{array}$ & $\begin{array}{l}-0.03 \\
(-1.08)\end{array}$ & $\begin{array}{l}-0.14^{*} \\
(-1.68)\end{array}$ & $\begin{array}{c}0.70^{* *} \\
(1.98)\end{array}$ & 21.64 \\
\hline $\mathrm{N}=5$ & $\begin{array}{l}21.94 \\
(1.33)\end{array}$ & $\begin{array}{c}1.69 \\
(1.40)\end{array}$ & $\begin{array}{c}0.73 \\
(1.06)\end{array}$ & $\begin{array}{c}4.10 \\
(1.27)\end{array}$ & $\begin{array}{l}-7.08 \\
(-1.08)\end{array}$ & $\begin{array}{l}-0.08 \\
(-1.58)\end{array}$ & $\begin{array}{l}-0.01 \\
(-0.16)\end{array}$ & $\begin{array}{c}0.79^{* * *} \\
(3.24)\end{array}$ & 15.25 \\
\hline $\mathrm{N}=6$ & $\begin{array}{l}32.00 \\
(1.47)\end{array}$ & $\begin{array}{c}2.02 \\
(1.57)\end{array}$ & $\begin{array}{c}1.41 \\
(1.46)\end{array}$ & $\begin{array}{c}5.79 \\
(1.37)\end{array}$ & $\begin{array}{l}-11.53 \\
(-1.39)\end{array}$ & $\begin{array}{l}-0.04 \\
(-1.64)\end{array}$ & $\begin{array}{c}0.02 \\
(0.46)\end{array}$ & $\begin{array}{c}0.56 \\
(1.44)\end{array}$ & 13.03 \\
\hline $\mathrm{N}=7$ & $\begin{array}{l}32.04 \\
(1.31)\end{array}$ & $\begin{array}{c}2.01 \\
(1.59)\end{array}$ & $\begin{array}{c}1.55 \\
(1.36)\end{array}$ & $\begin{array}{c}5.6 \\
(1.20)\end{array}$ & $\begin{array}{l}-12.8 \\
(-1.45)\end{array}$ & $\begin{array}{c}0.02 \\
(0.33)\end{array}$ & $\begin{array}{c}0.01 \\
(0.16)\end{array}$ & $\begin{array}{l}0.61^{*} \\
(1.67)\end{array}$ & 13.36 \\
\hline $\mathrm{N}=8$ & $\begin{array}{l}26.01 \\
(1.12)\end{array}$ & $\begin{array}{c}1.80 \\
(1.56)\end{array}$ & $\begin{array}{c}1.41 \\
(1.26)\end{array}$ & $\begin{array}{c}4.24 \\
(0.97)\end{array}$ & $\begin{array}{l}-11.82 \\
(-1.38)\end{array}$ & $\begin{array}{l}-0.04 \\
(-1.53)\end{array}$ & $\begin{array}{c}0.01 \\
(0.18)\end{array}$ & $\begin{array}{c}0.75^{* *} \\
(2.57)\end{array}$ & 11.00 \\
\hline $\mathrm{N}=9$ & $\begin{array}{l}21.07 \\
(1.17)\end{array}$ & $\begin{array}{c}1.98 \\
(1.59)\end{array}$ & $\begin{array}{c}1.14 \\
(1.28)\end{array}$ & $\begin{array}{c}3.15 \\
(0.95)\end{array}$ & $\begin{array}{l}-12.28 \\
(-1.46)\end{array}$ & $\begin{array}{c}-0.10^{* * * *} \\
(-2.83)\end{array}$ & $\begin{array}{l}-0.07 \\
(-1.32)\end{array}$ & $\begin{array}{c}0.70^{* * *} \\
(3.20)\end{array}$ & 10.99 \\
\hline $\mathrm{N}=10$ & $\begin{array}{c}23.26^{*} \\
(1.69)\end{array}$ & $\begin{array}{c}2.00 \\
(1.45)\end{array}$ & $\begin{array}{l}1.19^{*} \\
(1.85)\end{array}$ & $\begin{array}{c}3.47 \\
(1.34)\end{array}$ & $\begin{array}{c}-14.71^{*} \\
(-1.87)\end{array}$ & $\begin{array}{l}-0.02 \\
(-0.79)\end{array}$ & $\begin{array}{c}-0.03 \\
(-0.43)\end{array}$ & $\begin{array}{c}0.35 \\
(1.16)\end{array}$ & 7.26 \\
\hline $\mathrm{N}=11$ & $\begin{array}{l}24.04^{*} \\
(1.67)\end{array}$ & $\begin{array}{c}1.89 \\
(1.35)\end{array}$ & $\begin{array}{l}1.23^{*} \\
(1.79)\end{array}$ & $\begin{array}{c}3.52 \\
(1.26)\end{array}$ & $\begin{array}{c}-15.99^{*} \\
(-1.94)\end{array}$ & $\begin{array}{c}0.01 \\
(0.39)\end{array}$ & $\begin{array}{l}-0.02 \\
(-0.31)\end{array}$ & $\begin{array}{c}0.22 \\
(0.64)\end{array}$ & 7.39 \\
\hline $\mathrm{N}=12$ & $\begin{array}{l}21.82 \\
(1.56)\end{array}$ & $\begin{array}{c}1.59 \\
(1.14)\end{array}$ & $\begin{array}{c}1.18 \\
(1.54)\end{array}$ & $\begin{array}{c}2.98 \\
(1.11)\end{array}$ & $\begin{array}{c}-16.05^{*} \\
(-1.76)\end{array}$ & $\begin{array}{c}0.00 \\
(-0.10)\end{array}$ & $\begin{array}{c}0.03 \\
(0.58)\end{array}$ & $\begin{array}{c}0.25 \\
(0.83)\end{array}$ & 6.39 \\
\hline
\end{tabular}




\section{Table 11: Confirming the IVOL Puzzle in the Equity Market}

This table investigates the IVOL puzzle in the equity market. Systematic risk and idiosyncratic risk of individual stocks are estimated based on the Fama-French (2015) 5-factor model (MKT ${ }^{\text {Stock}}$, SMB, HML, RMW, and CMA) in Panel A and the Hou, Xue, and Zhang (2015) Q-factor model $\left(\mathrm{MKT}^{\text {Stock }}\right.$, ME, IA, and ROE) in Panel B. Quintile portfolios are formed every month by sorting stocks based on systematic risk and idiosyncratic risk. The estimation is based on daily returns in a month, requiring at least 15 daily observations in a month. The sample period is from July 1963 to June 2019 for the Fama-French (2015) 5-factor model and from January 1967 to June 2019 for the Q-factor model. Newey-West adjusted $t$-statistics are given in parentheses. ${ }^{*},{ }^{* *}$, and ${ }^{* * *}$ indicate the significance at the $10 \%, 5 \%$, and $1 \%$ level, respectively.

Panel A: SR and IR estimated using Fama-French (2015) 5-factor model

\begin{tabular}{|c|c|c|c|c|c|c|c|c|c|}
\hline & SR & $\begin{array}{l}\text { Avg } \\
\text { return }\end{array}$ & $\begin{array}{c}\text { FF 5-factor } \\
\text { alpha }\end{array}$ & $\begin{array}{l}\text { Q-factor } \\
\text { alpha }\end{array}$ & Low & IR & $\begin{array}{l}\text { Average } \\
\text { return }\end{array}$ & $\begin{array}{c}\text { FF 5-factor } \\
\text { alpha }\end{array}$ & $\begin{array}{c}\text { Q-factor } \\
\text { alpha }\end{array}$ \\
\hline Low & 0.00 & $\begin{array}{c}0.54 \\
(3.55)\end{array}$ & $\begin{array}{c}0.54 \\
(3.49)\end{array}$ & $\begin{array}{c}0.58 \\
(3.59)\end{array}$ & Low & 0.01 & $\begin{array}{c}0.55 \\
(3.51)\end{array}$ & $\begin{array}{c}0.58 \\
(3.59)\end{array}$ & $\begin{array}{c}0.63 \\
(3.78)\end{array}$ \\
\hline 2 & 0.01 & $\begin{array}{c}0.62 \\
(3.83)\end{array}$ & $\begin{array}{c}0.66 \\
(3.99)\end{array}$ & $\begin{array}{c}0.70 \\
(4.08)\end{array}$ & 2 & 0.02 & $\begin{array}{c}0.59 \\
(3.05)\end{array}$ & $\begin{array}{c}0.65 \\
(3.39)\end{array}$ & $\begin{array}{c}0.66 \\
(3.02)\end{array}$ \\
\hline 3 & 0.02 & $\begin{array}{c}0.63 \\
(3.26)\end{array}$ & $\begin{array}{c}0.68 \\
(3.52)\end{array}$ & $\begin{array}{c}0.70 \\
(3.29)\end{array}$ & 3 & 0.04 & $\begin{array}{c}0.66 \\
(2.71)\end{array}$ & $\begin{array}{c}0.74 \\
(3.13)\end{array}$ & $\begin{array}{c}0.74 \\
(2.64)\end{array}$ \\
\hline 4 & 0.04 & $\begin{array}{c}0.60 \\
(2.45)\end{array}$ & $\begin{array}{l}0.70 \\
(2.94)\end{array}$ & $\begin{array}{c}0.69 \\
(2.46)\end{array}$ & 4 & 0.08 & $\begin{array}{c}0.42 \\
(1.39)\end{array}$ & $\begin{array}{c}0.47 \\
(1.63)\end{array}$ & $\begin{array}{c}0.47 \\
(1.31)\end{array}$ \\
\hline High & 0.13 & $\begin{array}{c}0.13 \\
(0.39)\end{array}$ & $\begin{array}{c}0.24 \\
(0.72)\end{array}$ & $\begin{array}{c}0.17 \\
(0.42)\end{array}$ & High & 0.29 & $\begin{array}{c}-0.11 \\
(-0.30)\end{array}$ & $\begin{array}{l}-0.09 \\
(-0.26)\end{array}$ & $\begin{array}{l}-0.08 \\
(-0.19)\end{array}$ \\
\hline High - Low & & $\begin{array}{c}-0.41 \\
(-1.47)\end{array}$ & $\begin{array}{l}-0.30 \\
(-1.08)\end{array}$ & $\begin{array}{l}-0.41 \\
(-1.17)\end{array}$ & High - Low & & $\begin{array}{l}-0.65^{* *} \\
(-2.41)\end{array}$ & $\begin{array}{l}-0.67^{* *} \\
(-2.44)\end{array}$ & $\begin{array}{l}-0.70^{* *} \\
(-2.32)\end{array}$ \\
\hline
\end{tabular}

Panel B: SR and IR estimated using Hou, Xue, and Zhang (2015) Q-factor model

\begin{tabular}{|c|c|c|c|c|c|c|c|c|c|}
\hline & SR & $\begin{array}{c}\text { Average } \\
\text { return }\end{array}$ & $\begin{array}{c}\text { FF 5-factor } \\
\text { alpha }\end{array}$ & $\begin{array}{l}\text { Q-factor } \\
\text { alpha }\end{array}$ & & IR & $\begin{array}{c}\text { Average } \\
\text { return }\end{array}$ & $\begin{array}{c}\text { FF 5-factor } \\
\text { alpha }\end{array}$ & $\begin{array}{c}\text { Q-factor } \\
\text { alpha }\end{array}$ \\
\hline Low & 0.00 & $\begin{array}{c}0.55 \\
(3.46)\end{array}$ & $\begin{array}{c}0.55 \\
(3.42)\end{array}$ & $\begin{array}{c}0.52 \\
(3.30)\end{array}$ & Low & 0.01 & $\begin{array}{c}0.56 \\
(3.43)\end{array}$ & $\begin{array}{c}0.59 \\
(3.53)\end{array}$ & $\begin{array}{c}0.55 \\
(3.28)\end{array}$ \\
\hline 2 & 0.01 & $\begin{array}{c}0.62 \\
(3.67)\end{array}$ & $\begin{array}{c}0.67 \\
(3.86)\end{array}$ & $\begin{array}{c}0.59 \\
(3.49)\end{array}$ & 2 & 0.02 & $\begin{array}{c}0.58 \\
(2.83)\end{array}$ & $\begin{array}{c}0.65 \\
(3.18)\end{array}$ & $\begin{array}{c}0.55 \\
(2.68)\end{array}$ \\
\hline 3 & 0.02 & $\begin{array}{c}0.63 \\
(3.08)\end{array}$ & $\begin{array}{c}0.68 \\
(3.35)\end{array}$ & $\begin{array}{c}0.58 \\
(2.90)\end{array}$ & 3 & 0.04 & $\begin{array}{c}0.64 \\
(2.48)\end{array}$ & $\begin{array}{c}0.72 \\
(2.89)\end{array}$ & $\begin{array}{c}0.59 \\
(2.35)\end{array}$ \\
\hline 4 & 0.05 & $\begin{array}{c}0.56 \\
(2.19)\end{array}$ & $\begin{array}{c}0.67 \\
(2.67)\end{array}$ & $\begin{array}{c}0.50 \\
(2.01)\end{array}$ & 4 & 0.09 & $\begin{array}{c}0.39 \\
(1.22)\end{array}$ & $\begin{array}{c}0.44 \\
(1.44)\end{array}$ & $\begin{array}{c}0.30 \\
(1.02)\end{array}$ \\
\hline High & 0.15 & $\begin{array}{c}0.15 \\
(0.13)\end{array}$ & $\begin{array}{c}0.16 \\
(0.45)\end{array}$ & $\begin{array}{c}0.20 \\
(-0.15)\end{array}$ & High & 0.32 & $\begin{array}{c}-0.17 \\
(-0.45)\end{array}$ & $\begin{array}{c}-0.15 \\
(-0.43)\end{array}$ & $\begin{array}{c}-0.10 \\
(-0.19)\end{array}$ \\
\hline High - Low & & $\begin{array}{c}-0.45 \\
(-1.47)\end{array}$ & $\begin{array}{c}-0.40 \\
(-1.38)\end{array}$ & $\begin{array}{c}-0.30 \\
(-1.10)\end{array}$ & High - Low & & $\begin{array}{c}-0.73^{* *} \\
(-2.59)\end{array}$ & $\begin{array}{c}-0.74^{* *} \\
(-2.63)\end{array}$ & $\begin{array}{c}-0.65^{* *} \\
(-2.02)\end{array}$ \\
\hline
\end{tabular}




\section{Table 12: Institutional Ownership and Equity Idiosyncratic Risk}

Quintile portfolios are formed every month from January 1980 to June 2019 by first sorting individual stocks based on institutional ownership. Then within each institutional ownership quintile, individual stocks are further sorted into sub-quintiles based on their idiosyncratic risk. The benchmark model used to generate idiosyncratic risk is the Fama-French 5-factor model (MKT ${ }^{\text {Stock}}$ ), SMB, HML, RMW, and CMA). The estimation is based on daily returns in a month, requiring at least 15 daily observations in a month. "INST,1" is the portfolio of stocks with the lowest institutional ownership and "INST,5" is the portfolio of stocks with the highest institutional ownership. The portfolios are value-weighted using market cap as weights. Table reports the next-month average excess return, the Fama-French 5-factor alpha, and the Q-factor alpha between the highest and lowest quintile within each institutional ownership quintile. Newey-West adjusted $t$-statistics are given in parentheses. ${ }^{*},{ }^{* *}$, and ${ }^{* * *}$ indicate the significance at the $10 \%, 5 \%$, and $1 \%$ level, respectively.

\begin{tabular}{|c|c|c|c|c|c|c|c|c|}
\hline & $\mathrm{IR}, 1$ & $\mathrm{IR}, 2$ & IR, 3 & $\mathrm{IR}, 4$ & IR, 5 & $\mathrm{IR}, 5-\mathrm{IR}, 1$ & $\begin{array}{c}\text { FF 5-factor } \\
\text { alpha }\end{array}$ & $\begin{array}{c}\text { Q-factor } \\
\text { alpha }\end{array}$ \\
\hline INST, 1 & 0.72 & 0.64 & 0.66 & -0.08 & -1.28 & $\begin{array}{c}-2.01^{* * *} \\
(-5.23)\end{array}$ & $\begin{array}{c}-1.82^{* * *} \\
(-4.71)\end{array}$ & $\begin{array}{c}-1.87^{* * *} \\
(-4.15)\end{array}$ \\
\hline INST, 2 & 0.63 & 0.65 & 0.52 & -0.05 & -0.58 & $\begin{array}{c}-1.21^{* * *} \\
(-2.74)\end{array}$ & $\begin{array}{l}-1.03^{* *} \\
(-2.38)\end{array}$ & $\begin{array}{l}-1.07^{* *} \\
(-2.22)\end{array}$ \\
\hline INST,3 & 0.87 & 0.69 & 0.58 & 0.33 & -0.19 & $\begin{array}{c}-1.07^{* * *} \\
(-2.88)\end{array}$ & $\begin{array}{c}-1.04^{* * *} \\
(-2.81)\end{array}$ & $\begin{array}{c}-1.08^{* *} \\
(-2.49)\end{array}$ \\
\hline INST, 4 & 0.82 & 0.73 & 0.76 & 0.81 & 0.40 & $\begin{array}{l}-0.41 \\
(-1.51)\end{array}$ & $\begin{array}{c}-0.47 \\
(-1.56)\end{array}$ & $\begin{array}{l}-0.40 \\
(-1.12)\end{array}$ \\
\hline INST, 5 & 0.85 & 0.81 & 0.85 & 0.78 & 0.75 & $\begin{array}{l}-0.10 \\
(-0.41)\end{array}$ & $\begin{array}{l}-0.09 \\
(-0.32)\end{array}$ & $\begin{array}{l}-0.09 \\
(-0.30)\end{array}$ \\
\hline
\end{tabular}




\section{Table 13: Institutional Ownership and Bond Idiosyncratic Risk}

Quintile portfolios are formed every month from January 2001 to December 2017 by first sorting corporate bonds based on institutional ownership. Then within each institutional ownership quintile, individual bonds are further sorted into sub-quintiles based on their idiosyncratic risk. The benchmark model used to generate idiosyncratic risk is the BBW 4-factor model (MKT, DRF, CRF, and LRF). "INST,1" is the portfolio of bonds with the lowest institutional ownership and "INST,5" is the portfolio of bonds with the highest institutional ownership. The portfolios are value-weighted using bond amount outstanding as weights. Table reports the 10-factor alpha between the highest- and lowest-IR quintile within each institutional ownership quintile. Newey-West adjusted $t$-statistics are given in parentheses. ${ }^{*},{ }^{* *}$, and ${ }^{* * *}$ indicate the significance at the $10 \%, 5 \%$, and $1 \%$ level, respectively.

\begin{tabular}{|c|c|c|c|c|c|c|c|}
\hline & $\mathrm{IR}, 1$ & $\mathrm{IR}, 2$ & $\mathrm{IR}, 3$ & $\mathrm{IR}, 4$ & $\mathrm{IR}, 5$ & $\mathrm{IR}, 5-\mathrm{IR}, 1$ & 10-factor alpha \\
\hline INST, 1 & 0.18 & 0.41 & 0.33 & 0.65 & 0.63 & $\begin{array}{c}0.45 \\
(1.27)\end{array}$ & $\begin{array}{c}0.12 \\
(0.29)\end{array}$ \\
\hline INST, 2 & 0.18 & 0.33 & 0.47 & 0.48 & 0.49 & $\begin{array}{c}0.32 \\
(1.63)\end{array}$ & $\begin{array}{c}-0.01 \\
(-0.05)\end{array}$ \\
\hline INST, 3 & 0.19 & 0.31 & 0.44 & 0.52 & 0.48 & $\begin{array}{c}0.29 \\
(1.57)\end{array}$ & $\begin{array}{c}0.05 \\
(0.36)\end{array}$ \\
\hline INST, 4 & 0.20 & 0.33 & 0.41 & 0.47 & 0.52 & $\begin{array}{c}0.31 \\
(1.37)\end{array}$ & $\begin{array}{c}0.17 \\
(1.47)\end{array}$ \\
\hline INST, 5 & 0.21 & 0.38 & 0.45 & 0.52 & 0.53 & $\begin{array}{c}0.32 \\
(1.38)\end{array}$ & $\begin{array}{c}0.01 \\
(0.08)\end{array}$ \\
\hline
\end{tabular}




\section{Is There a Risk-Return Tradeoff in the Corporate Bond Market? Time-Series and Cross-Sectional Evidence}

\section{Online Appendix}

To save space in the paper, we present the robustness check results in the Online Appendix. Table A.1 tests if our findings in Table 1 are sensitive to an alternative approach to estimating the risk-return tradeoff using the GARCH-in-Mean model. Table A.2 presents results from univariate portfolios of corporate bonds sorted by total variance (VOL). Table A.3 examines the univariate portfolio results separately for bonds with investment-grade and non-investmentgrade ratings. Table A.4 reports the quintile portfolios of corporate bonds sorted by systematic risk (SR) for different subperiods from January 1997 to June 2019 (including the crisis and the postcrisis/recovery periods). Table A.5 presents results from the firm-level univariate portfolios of corporate bonds sorted by SR using the median size bond or the most liquid bond as the representative for the firm. Table A.6 presents results from the firm-level Fama and MacBeth (1973) cross-sectional regressions of one-month-ahead corporate bond excess returns on the SR, with and without controls. Table A.7 replicates Table 9 by replacing the value-weighted aggregate systematic risk (SR) with the equal-, and rating-weighted systematic risk of individual bonds. Table A.8 reports the time-series predictive power of the value-,

equal-, and rating-weighted average of total variance $\left(\sigma_{m}^{2}\right)$ of individual bonds in predicting one-month-ahead returns on the value-weighted corporate bond market index (VW'bond) and the Merrill Lynch bond index (MRL $\left.\mathrm{Mond}^{\text {bon }}\right)$. 


\section{Table A.1: Estimating the Intertemporal Risk-Return Tradeoff in the Corporate Bond and Equity Markets Using the GARCH-in-Mean and GJRGARCH-in-Mean Models}

This table investigates the intertemporal relation between expected return and risk of bond and stock market returns based on the following GARCH-in-Mean and Threshold GARCH (GJR-GARCH) models:

$$
\begin{gathered}
R_{m, t+1}=\alpha+\beta \cdot \sigma_{m, t+1 \mid t}^{2}+\epsilon_{m, t+1} \\
\text { GARCH: } \quad E_{t}\left(\epsilon_{m, t+1}^{2} \mid \Omega_{t}\right)=\sigma_{m, t+1 \mid t}^{2}=\theta_{0}+\theta_{1} \epsilon_{m, t}^{2}+\theta_{2} \sigma_{m, t}^{2} \\
\text { GJR-GARCH: } \quad E_{t}\left(\epsilon_{m, t+1}^{2} \mid \Omega_{t}\right)=\sigma_{m, t+1 \mid t}^{2}=\theta_{0}+\theta_{1} \epsilon_{m, t}^{2}+\theta_{2} \sigma_{m, t}^{2}+\theta_{3} D_{t} \epsilon_{m, t}^{2} \\
D_{t}=1 \text { if } \epsilon_{m, t}<0, \text { and } D_{t}=0 \text { otherwise }
\end{gathered}
$$

where $R_{m, t+1}$ is the monthly excess return of the bond or stock market in month $t+1$ and $\sigma_{m, t+1 \mid t}^{2}$ is the time- $t$ expected conditional variance of excess bond or stock market returns at time $t+1$; $\sigma_{m, t+1 \mid t}^{2}=E_{t}\left(\sigma_{m, t+1}^{2}\right) . \Omega_{t}$ denotes the information set available at time $t$ and the one-month-ahead conditional variance of bond or stock market returns, $\sigma_{m, t+1 \mid t}$, is defined as a function of the current unexpected news in the bond or stock market $\left(\epsilon_{m, t}^{2}\right)$ and the current variance $\left(\sigma_{m, t}^{2}\right)$.

\begin{tabular}{|c|c|c|c|c|c|c|c|c|}
\hline & $\alpha$ & $\beta$ & $\theta_{0}$ & $\theta_{1}$ & $\theta_{2}$ & $\theta_{3}$ & $\operatorname{Adj}-R^{2}$ & Sample Period \\
\hline $\begin{array}{l}\text { Value-Weighted } \\
\text { Bond Index }\end{array}$ & $\begin{array}{c}-0.0002 \\
(-0.12)\end{array}$ & $\begin{array}{l}18.120 \\
(2.47)\end{array}$ & $\begin{array}{c}0.0002 \\
(1.52)\end{array}$ & $\begin{array}{c}0.1953 \\
(1.88)\end{array}$ & $\begin{array}{c}0.7025 \\
(6.01)\end{array}$ & $\begin{array}{c}0.0238 \\
(0.26)\end{array}$ & $5.52 \%$ & Jan 1997 - June 2019 \\
\hline $\begin{array}{l}\text { Value-Weighted CRSP } \\
\text { Stock Index }\end{array}$ & $\begin{array}{c}0.0079 \\
(1.84)\end{array}$ & $\begin{array}{c}-0.9768 \\
(-0.38)\end{array}$ & $\begin{array}{l}0.0002 \\
(2.36)\end{array}$ & $\begin{array}{c}0.0116 \\
(0.14)\end{array}$ & $\begin{array}{l}0.7040 \\
(7.20)\end{array}$ & $\begin{array}{l}0.4088 \\
(3.25)\end{array}$ & $-0.53 \%$ & Jan 1997 - June 2019 \\
\hline $\begin{array}{l}\text { Value-Weighted CRSP } \\
\text { Stock Index }\end{array}$ & $\begin{array}{c}0.0059 \\
(3.38)\end{array}$ & $\begin{array}{c}0.7242 \\
(1.03)\end{array}$ & $\begin{array}{c}0.0001 \\
(4.84)\end{array}$ & $\begin{array}{c}0.0645 \\
(2.61)\end{array}$ & $\begin{array}{l}0.8328 \\
(47.11)\end{array}$ & $\begin{array}{l}0.1235 \\
(3.86)\end{array}$ & $0.05 \%$ & July 1926 - June 2019 \\
\hline
\end{tabular}

Panel A: GARCH-in-Mean model

\begin{tabular}{lcccccc|c|c}
\hline & $\alpha$ & $\beta$ & $\theta_{0}$ & $\theta_{1}$ & $\theta_{2}$ & $\theta_{3}$ & Adj- $R^{2}$ & Sample Period \\
\hline Value-Weighted & -0.0005 & 20.132 & 0.00002 & 0.2012 & 0.7045 & & $5.96 \%$ & Jan 1997 - June 2019 \\
Bond Index & $(-0.34)$ & $(2.62)$ & $(1.55)$ & $(2.71)$ & $(6.06)$ & & & \\
& & & & & & & & \\
Value-Weighted CRSP & 0.0067 & 1.2409 & 0.00011 & 0.2226 & 0.7418 & - & $-0.83 \%$ & Jan 1997 - June 2019 \\
Stock Index & $(1.47)$ & $(0.47)$ & $(1.50)$ & $(3.21)$ & $(9.05)$ & & & \\
Value-Weighted CRSP & 0.0061 & 1.1319 & 0.00008 & 0.1414 & 0.8369 & & \multirow{2}{*}{$-0.10 \%$} & July 1926 - June 2019 \\
Stock Index & $(3.31)$ & $(1.50)$ & $(3.93)$ & $(7.37)$ & $(49.45)$ & - & -
\end{tabular}

Panel B: GJRGARCH-in-Mean model 


\section{Table A.2: Univariate portfolios of corporate bonds sorted by total variance (VOL)}

Quintile portfolios are formed every month from January 1997 to June 2019 by sorting corporate bonds based on the total variance. Quintile 1 is the portfolio with the lowest VOL and Quintile 5 is the portfolio with the highest VOL. The portfolios are value-weighted using amount outstanding as weights. Table reports the average VOL (\%), the next-month average excess return, the 5-factor alpha from stock market factors, the 5-factor alpha from bond market factors, and the 10-factor alpha for each quintile. The last six columns report average portfolio characteristics including bond beta $\left(\beta^{M K T}\right)$, illiquidity (ILLIQ), downside risk (5\% Value-at-Risk), credit rating, time-to-maturity (years), and amount outstanding (size, in \$billion) for each quintile. The last row shows the differences in monthly average returns, the differences in alphas with respect to the factor models. The 5 -factor model with stock market factors includes the excess stock market return $\left(\mathrm{MKT}^{\text {Stock }}\right)$, the size factor $(\mathrm{SMB})$, the book-to-market factor (HML), the momentum factor $\left(\mathrm{MOM}^{\text {Stock }}\right)$, and the stock liquidity factor $\left(\mathrm{LIQ}^{\text {Stock }}\right)$. The 5-factor model with bond market factors includes the excess bond market return $(\mathrm{MKT})$, the default factor (DEF), the term factor (TERM), the bond momentum factor $\left(\mathrm{MOM}^{\text {Bond }}\right)$, and the bond liquidity factor $\left(\mathrm{LIQ} \mathrm{Q}^{\text {Bond }}\right)$. The 10 -factor model combines the five stock and five bond market factors. Average excess returns and alphas are defined in monthly percentage terms. Newey-West adjusted $t$-statistics are given in parentheses. ${ }^{*},{ }^{* *}$, and ${ }^{* * *}$ indicate the significance at the $10 \%, 5 \%$, and $1 \%$ level, respectively.

\begin{tabular}{|c|c|c|c|c|c|c|c|c|c|c|c|}
\hline \multirow[t]{2}{*}{ Quintiles } & \multirow{2}{*}{$\begin{array}{c}\text { Average } \\
\text { VOL }\end{array}$} & \multirow{2}{*}{$\begin{array}{c}\text { Average } \\
\text { return }\end{array}$} & \multirow{2}{*}{$\begin{array}{c}5 \text {-factor stock } \\
\text { alpha }\end{array}$} & \multirow{2}{*}{$\begin{array}{c}\text { 5-factor bond } \\
\text { alpha }\end{array}$} & \multirow{2}{*}{$\begin{array}{c}\text { 10-factor } \\
\text { alpha }\end{array}$} & \multicolumn{6}{|c|}{ Average portfolio characteristics } \\
\hline & & & & & & $\beta^{M K T}$ & ILLIQ & VaR & Rating & Maturity & Size \\
\hline Low & 0.02 & $\begin{array}{c}0.18 \\
(3.24)\end{array}$ & $\begin{array}{c}0.16 \\
(2.56)\end{array}$ & $\begin{array}{c}0.04 \\
(1.43)\end{array}$ & $\begin{array}{c}-0.02 \\
(-0.73)\end{array}$ & 0.46 & 0.33 & 1.52 & 6.77 & 3.70 & 0.64 \\
\hline 2 & 0.05 & $\begin{array}{c}0.33 \\
(3.52)\end{array}$ & $\begin{array}{c}0.26 \\
(2.64)\end{array}$ & $\begin{array}{c}0.09 \\
(1.92)\end{array}$ & $\begin{array}{c}0.08 \\
(0.90)\end{array}$ & 0.70 & 0.78 & 2.68 & 7.68 & 6.49 & 0.55 \\
\hline 3 & 0.09 & $\begin{array}{c}0.42 \\
(3.44)\end{array}$ & $\begin{array}{c}0.33 \\
(2.55)\end{array}$ & $\begin{array}{c}0.13 \\
(2.46)\end{array}$ & $\begin{array}{c}0.13 \\
(2.33)\end{array}$ & 0.87 & 1.23 & 3.84 & 8.10 & 9.80 & 0.48 \\
\hline 4 & 0.21 & $\begin{array}{c}0.56 \\
(3.40)\end{array}$ & $\begin{array}{c}0.39 \\
(2.60)\end{array}$ & $\begin{array}{c}0.27 \\
(3.67)\end{array}$ & $\begin{array}{c}0.22 \\
(2.77)\end{array}$ & 1.20 & 1.90 & 5.75 & 8.38 & 14.46 & 0.47 \\
\hline High & 1.22 & $\begin{array}{c}1.14 \\
(4.30)\end{array}$ & $\begin{array}{c}0.81 \\
(3.52)\end{array}$ & $\begin{array}{c}0.96 \\
(5.08)\end{array}$ & $\begin{array}{c}0.78 \\
(3.28)\end{array}$ & 1.68 & 3.32 & 12.46 & 11.71 & 12.81 & 0.40 \\
\hline High - Low & & $\begin{array}{c}0.96^{* * *} \\
(3.99)\end{array}$ & $\begin{array}{c}0.65^{* * *} \\
(3.01)\end{array}$ & $\begin{array}{c}0.92^{* * *} \\
(4.76)\end{array}$ & $\begin{array}{c}0.73^{* * *} \\
(3.05)\end{array}$ & & & & & & \\
\hline
\end{tabular}




\section{Table A.3: Investment-Grade Versus Non-Investment-Grade Corporate Bonds}

This table repeats the univariate portfolio analyses in Tables 5-6 by sorting corporate bonds based on the systematic risk (SR) and idiosyncratic risk (IR) for investment-grade corporate bonds in Panel A and non-investment-grade bonds in Panel B.

Panel A: Investment-grade bonds

\begin{tabular}{|c|c|c|c|c|}
\hline & \multicolumn{2}{|c|}{$\mathrm{SR}$} & \multicolumn{2}{|c|}{ IR } \\
\hline & $\begin{array}{l}\text { Average } \\
\text { return }\end{array}$ & $\begin{array}{c}\text { 10-factor } \\
\text { alpha }\end{array}$ & $\begin{array}{l}\text { Average } \\
\text { return }\end{array}$ & $\begin{array}{c}\text { 10-factor } \\
\text { alpha }\end{array}$ \\
\hline Low & $\begin{array}{c}0.15 \\
(3.48)\end{array}$ & $\begin{array}{c}0.05 \\
(0.23)\end{array}$ & $\begin{array}{c}0.15 \\
(3.21)\end{array}$ & $\begin{array}{c}0.03 \\
(1.26)\end{array}$ \\
\hline 2 & $\begin{array}{c}0.30 \\
(4.35)\end{array}$ & $\begin{array}{c}0.12 \\
(2.16)\end{array}$ & $\begin{array}{c}0.28 \\
(3.98)\end{array}$ & $\begin{array}{c}0.09 \\
(3.06)\end{array}$ \\
\hline 3 & $\begin{array}{c}0.38 \\
(4.05)\end{array}$ & $\begin{array}{c}0.15 \\
(2.32)\end{array}$ & $\begin{array}{c}0.35 \\
(3.71)\end{array}$ & $\begin{array}{c}0.10 \\
(2.53)\end{array}$ \\
\hline 4 & $\begin{array}{c}0.52 \\
(4.23)\end{array}$ & $\begin{array}{c}0.22 \\
(2.60)\end{array}$ & $\begin{array}{c}0.47 \\
(3.85)\end{array}$ & $\begin{array}{c}0.15 \\
(3.19)\end{array}$ \\
\hline High & $\begin{array}{c}0.63 \\
(3.97)\end{array}$ & $\begin{array}{c}0.35 \\
(2.96)\end{array}$ & $\begin{array}{c}0.50 \\
(3.16)\end{array}$ & $\begin{array}{c}0.12 \\
(1.01)\end{array}$ \\
\hline High - Low & $\begin{array}{c}0.48^{* * *} \\
(3.50)\end{array}$ & $\begin{array}{l}0.30^{* *} \\
(2.18)\end{array}$ & $\begin{array}{l}0.35^{* *} \\
(2.66)\end{array}$ & $\begin{array}{c}0.09 \\
(0.69)\end{array}$ \\
\hline
\end{tabular}

Panel B: Non-investment-grade bonds

\begin{tabular}{|c|c|c|c|c|}
\hline & \multicolumn{2}{|c|}{ SR } & \multicolumn{2}{|c|}{ IR } \\
\hline & $\begin{array}{l}\text { Average } \\
\text { return }\end{array}$ & $\begin{array}{c}\text { 10-factor } \\
\text { alpha }\end{array}$ & $\begin{array}{l}\text { Average } \\
\text { return }\end{array}$ & $\begin{array}{c}\text { 10-factor } \\
\text { alpha }\end{array}$ \\
\hline Low & $\begin{array}{c}0.43 \\
(4.00)\end{array}$ & $\begin{array}{c}0.25 \\
(2.78)\end{array}$ & $\begin{array}{c}0.36 \\
(3.43)\end{array}$ & $\begin{array}{c}0.16 \\
(1.76)\end{array}$ \\
\hline 2 & $\begin{array}{c}0.48 \\
(2.95)\end{array}$ & $\begin{array}{c}0.19 \\
(1.68)\end{array}$ & $\begin{array}{c}0.50 \\
(3.04)\end{array}$ & $\begin{array}{c}0.21 \\
(2.02)\end{array}$ \\
\hline 3 & $\begin{array}{c}0.55 \\
(2.43)\end{array}$ & $\begin{array}{c}0.15 \\
(1.32)\end{array}$ & $\begin{array}{c}0.46 \\
(2.04)\end{array}$ & $\begin{array}{c}0.08 \\
(0.74)\end{array}$ \\
\hline 4 & $\begin{array}{c}0.64 \\
(1.99)\end{array}$ & $\begin{array}{c}0.22 \\
(0.96)\end{array}$ & $\begin{array}{c}0.51 \\
(1.71)\end{array}$ & $\begin{array}{c}0.05 \\
(0.26)\end{array}$ \\
\hline High & $\begin{array}{l}1.36 \\
(3.00)\end{array}$ & $\begin{array}{c}0.94 \\
(2.32)\end{array}$ & $\begin{array}{c}0.69 \\
(1.85)\end{array}$ & $\begin{array}{c}0.21 \\
(0.73)\end{array}$ \\
\hline High - Low & $\begin{array}{c}0.94^{* * *} \\
(2.78)\end{array}$ & $\begin{array}{l}0.71^{* *} \\
(2.54)\end{array}$ & $\begin{array}{c}0.33 \\
(1.12)\end{array}$ & $\begin{array}{c}0.06 \\
(0.19)\end{array}$ \\
\hline
\end{tabular}




\section{Table A.4: Subperiod Analyses}

This table repeats the univariate portfolio analyses in Tables $5-6$ by sorting corporate bonds based on the systematic risk (SR) and idiosyncratic risk (IR) for three subperiods (i) the first pre-crisis subperiod from January 1997 to July 2007, (ii) the second subperiod including the crisis from August 2007 to December 2012, and (iii) the third most recent subperiod from January 2013 to June 2019.

Panel A: Corporate bonds sorted by SR

\begin{tabular}{|c|c|c|c|c|c|c|}
\hline \multirow[b]{3}{*}{ Low } & $\begin{array}{c}\text { Average } \\
\text { return }\end{array}$ & $\begin{array}{c}\text { 10-factor } \\
\text { alpha }\end{array}$ & $\begin{array}{c}\text { Average } \\
\text { return }\end{array}$ & $\begin{array}{c}\text { 10-factor } \\
\text { alpha }\end{array}$ & $\begin{array}{c}\text { Average } \\
\text { return }\end{array}$ & $\begin{array}{c}\text { 10-factor } \\
\text { alpha }\end{array}$ \\
\hline & \multicolumn{2}{|c|}{ Subperiod I } & \multicolumn{2}{|c|}{ Subperiod II } & \multicolumn{2}{|c|}{ Subperiod III } \\
\hline & $\begin{array}{c}0.08 \\
(0.93)\end{array}$ & $\begin{array}{c}0.06 \\
(0.78)\end{array}$ & $\begin{array}{c}0.33 \\
(2.46)\end{array}$ & $\begin{array}{l}-0.02 \\
(-0.32)\end{array}$ & $\begin{array}{c}0.13 \\
(4.63)\end{array}$ & $\begin{array}{c}0.01 \\
(0.90)\end{array}$ \\
\hline 2 & $\begin{array}{c}0.18 \\
(1.44)\end{array}$ & $\begin{array}{c}0.14 \\
(1.41)\end{array}$ & $\begin{array}{c}0.63 \\
(2.94)\end{array}$ & $\begin{array}{c}0.11 \\
(1.75)\end{array}$ & $\begin{array}{c}0.21 \\
(3.23)\end{array}$ & $\begin{array}{c}0.16 \\
(2.64)\end{array}$ \\
\hline 3 & $\begin{array}{c}0.21 \\
(1.61)\end{array}$ & $\begin{array}{c}0.16 \\
(1.79)\end{array}$ & $\begin{array}{c}0.77 \\
(2.58)\end{array}$ & $\begin{array}{c}0.08 \\
(0.95)\end{array}$ & $\begin{array}{c}0.27 \\
(2.73)\end{array}$ & $\begin{array}{c}0.19 \\
(2.03)\end{array}$ \\
\hline 4 & $\begin{array}{c}0.36 \\
(2.09)\end{array}$ & $\begin{array}{c}0.29 \\
(2.74)\end{array}$ & $\begin{array}{c}0.90 \\
(2.53)\end{array}$ & $\begin{array}{c}0.37 \\
(2.81)\end{array}$ & $\begin{array}{c}0.35 \\
(2.21)\end{array}$ & $\begin{array}{c}0.22 \\
(1.35)\end{array}$ \\
\hline High & $\begin{array}{c}0.59 \\
(2.12)\end{array}$ & $\begin{array}{c}0.46 \\
(3.19)\end{array}$ & $\begin{array}{c}1.54 \\
(2.48)\end{array}$ & $\begin{array}{c}1.12 \\
(2.99)\end{array}$ & $\begin{array}{c}0.67 \\
(2.60)\end{array}$ & $\begin{array}{c}0.47 \\
(1.69)\end{array}$ \\
\hline High - Low & $\begin{array}{l}0.51^{* *} \\
(2.20)\end{array}$ & $\begin{array}{c}0.41^{* * *} \\
(3.01)\end{array}$ & $\begin{array}{l}1.21^{* *} \\
(2.16)\end{array}$ & $\begin{array}{c}1.14^{* * *} \\
(2.82)\end{array}$ & $\begin{array}{l}0.54^{* *} \\
(2.27)\end{array}$ & $\begin{array}{l}0.46^{* *} \\
(2.14)\end{array}$ \\
\hline
\end{tabular}

Panel B: Corporate bonds sorted by IR

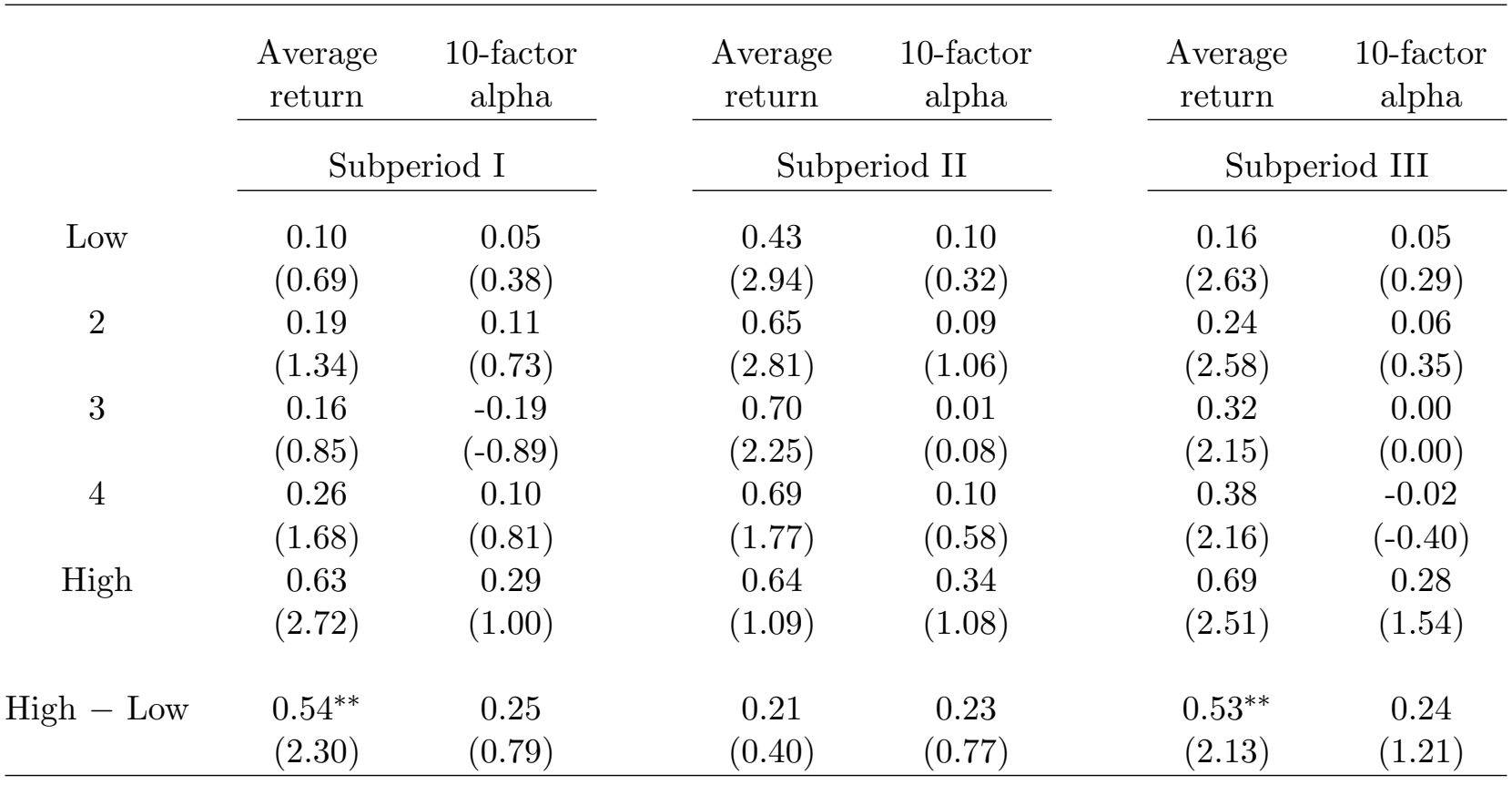




\section{Table A.5: Firm-level Univariate Portfolios of Corporate Bonds Sorted by SR}

This table repeats the univariate portfolio analyses in Table 5 by sorting corporate bonds based on the systematic risk (SR) at the firm-level. To control for bonds issued by the same firm, for each month in our sample, we pick one bond with the median size (Panel A) or the most liquid bond (Panel B) as the representative for the firm.

\begin{tabular}{|c|c|c|c|c|}
\hline & \multicolumn{2}{|c|}{ Panel A: Using the median size bond } & \multicolumn{2}{|c|}{ Panel B: Using the most liquid bond } \\
\hline & $\begin{array}{c}\text { Average } \\
\text { return }\end{array}$ & $\begin{array}{c}\text { 10-factor } \\
\text { alpha }\end{array}$ & $\begin{array}{c}\text { Average } \\
\text { return }\end{array}$ & $\begin{array}{c}\text { 10-factor } \\
\text { alpha }\end{array}$ \\
\hline Low & $\begin{array}{c}0.19 \\
(3.56)\end{array}$ & $\begin{array}{c}-0.06 \\
(-0.92)\end{array}$ & $\begin{array}{c}0.19 \\
(3.57)\end{array}$ & $\begin{array}{c}0.03 \\
(0.65)\end{array}$ \\
\hline 2 & $\begin{array}{c}0.34 \\
(4.09)\end{array}$ & $\begin{array}{c}0.13 \\
(1.06)\end{array}$ & $\begin{array}{c}0.35 \\
(4.10)\end{array}$ & $\begin{array}{c}0.13 \\
(1.13)\end{array}$ \\
\hline 3 & $\begin{array}{c}0.42 \\
(3.70)\end{array}$ & $\begin{array}{c}0.15 \\
(2.02)\end{array}$ & $\begin{array}{c}0.42 \\
(3.71)\end{array}$ & $\begin{array}{c}0.15 \\
(2.05)\end{array}$ \\
\hline 4 & $\begin{array}{c}0.54 \\
(3.76)\end{array}$ & $\begin{array}{c}0.20 \\
(3.76)\end{array}$ & $\begin{array}{c}0.54 \\
(3.77)\end{array}$ & $\begin{array}{c}0.21 \\
(3.86)\end{array}$ \\
\hline High & $\begin{array}{c}0.83 \\
(3.51)\end{array}$ & $\begin{array}{c}0.42 \\
(1.81)\end{array}$ & $\begin{array}{c}0.78 \\
(3.66)\end{array}$ & $\begin{array}{c}0.45 \\
(2.99)\end{array}$ \\
\hline High - Low & $\begin{array}{c}0.64^{* * *} \\
(3.06)\end{array}$ & $\begin{array}{l}0.49^{* *} \\
(2.48)\end{array}$ & $\begin{array}{c}0.60^{* * *} \\
(3.23)\end{array}$ & $\begin{array}{l}0.45^{* *} \\
(2.26)\end{array}$ \\
\hline
\end{tabular}


Table A.6: Firm-level Fama-MacBeth Cross-Sectional Regressions

This table repeats the Fama and MacBeth (1973) cross-sectional regressions of one-month-ahead corporate bond excess returns on systematic risk and idiosyncratic risk with and without control variables in Table 8 at the firm-level. To control for bonds issued by the same firm, for each month in our sample, we pick one bond with the median size (Panel A) or the most liquid bond (Panel B) as the representative for the firm.

Panel A: Using the median size bond

\begin{tabular}{|c|c|c|c|c|c|c|c|c|c|c|c|c|}
\hline & Intercept & $\mathrm{SR}$ & IR & $\beta^{M K T}$ & $\beta^{D E F}$ & $\beta^{T E R M}$ & Rating & ILLIQ & Maturity & Size & REV & Adj. $R^{2}(\%)$ \\
\hline (1) & $\begin{array}{l}0.387 \\
(2.93)\end{array}$ & $\begin{array}{l}\mathbf{1 . 2 2 4} \\
(3.74)\end{array}$ & & & & & & & & & & 6.52 \\
\hline$(2)$ & $\begin{array}{l}0.361 \\
(3.03)\end{array}$ & & $\begin{array}{c}0.405 \\
(1.26)\end{array}$ & & & & & & & & & 5.03 \\
\hline (3) & $\begin{array}{l}0.331 \\
(2.65)\end{array}$ & $\begin{array}{l}\mathbf{1 . 2 4 3} \\
(2.46)\end{array}$ & $\begin{array}{c}0.370 \\
(0.44)\end{array}$ & & & & & & & & & 8.81 \\
\hline (4) & $\begin{array}{l}0.035 \\
(0.20)\end{array}$ & $\begin{array}{l}\mathbf{1 . 5 1 1} \\
(2.49)\end{array}$ & & $\begin{array}{c}0.020 \\
(0.32)\end{array}$ & $\begin{array}{l}-0.039 \\
(-0.58)\end{array}$ & $\begin{array}{l}-0.044 \\
(-0.44)\end{array}$ & $\begin{array}{l}0.031 \\
(1.40)\end{array}$ & $\begin{array}{l}\mathbf{0 . 0 2 7} \\
(3.26)\end{array}$ & $\begin{array}{l}0.007 \\
(0.63)\end{array}$ & $\begin{array}{c}0.040 \\
(0.45)\end{array}$ & $\begin{array}{c}-\mathbf{0 . 1 0 2} \\
(-8.45)\end{array}$ & 21.60 \\
\hline (5) & $\begin{array}{l}0.485 \\
(1.24)\end{array}$ & & $\begin{array}{c}0.819 \\
(0.75)\end{array}$ & $\begin{array}{c}0.012 \\
(0.21)\end{array}$ & $\begin{array}{l}-0.112 \\
(-1.33)\end{array}$ & $\begin{array}{l}0.110 \\
(0.98)\end{array}$ & $\begin{array}{l}0.014 \\
(0.66)\end{array}$ & $\begin{array}{l}\mathbf{0 . 0 4 9} \\
(3.05)\end{array}$ & $\begin{array}{l}-0.017 \\
(-0.71)\end{array}$ & $\begin{array}{c}0.027 \\
(0.59)\end{array}$ & $\begin{array}{c}-\mathbf{0 . 1 2 2} \\
(-9.88)\end{array}$ & 20.41 \\
\hline (6) & $\begin{array}{l}-0.047 \\
(-0.46)\end{array}$ & $\begin{array}{l}\mathbf{1 . 4 9 2} \\
(2.27) \\
\end{array}$ & $\begin{array}{c}0.066 \\
(0.06) \\
\end{array}$ & $\begin{array}{c}0.015 \\
(0.18)\end{array}$ & $\begin{array}{l}-0.102 \\
(-1.14)\end{array}$ & $\begin{array}{l}0.084 \\
(0.73)\end{array}$ & $\begin{array}{l}0.028 \\
(1.50) \\
\end{array}$ & $\begin{array}{l}\mathbf{0 . 0 3 1} \\
(2.93)\end{array}$ & $\begin{array}{l}0.004 \\
(0.97) \\
\end{array}$ & $\begin{array}{c}0.051 \\
(0.83)\end{array}$ & $\begin{array}{c}\mathbf{- 0 . 0 9 7} \\
(-7.20)\end{array}$ & 22.06 \\
\hline
\end{tabular}

Panel B: Using the most liquid bond

\begin{tabular}{|c|c|c|c|c|c|c|c|c|c|c|c|c|}
\hline & Intercept & $\mathrm{SR}$ & IR & $\beta^{M K T}$ & $\beta^{D E F}$ & $\beta^{T E R M}$ & Rating & ILLIQ & Maturity & Size & REV & Adj. $R^{2}(\%)$ \\
\hline (1) & $\begin{array}{l}0.391 \\
(2.95)\end{array}$ & $\begin{array}{l}\mathbf{1 . 4 3 4} \\
(4.06)\end{array}$ & & & & & & & & & & 6.65 \\
\hline$(2)$ & $\begin{array}{l}0.376 \\
(3.17)\end{array}$ & & $\begin{array}{l}\mathbf{0 . 6 2 0} \\
(2.25)\end{array}$ & & & & & & & & & 4.91 \\
\hline$(3)$ & $\begin{array}{l}0.335 \\
(2.67)\end{array}$ & $\begin{array}{l}\mathbf{0 . 6 1 7} \\
(2.44)\end{array}$ & $\begin{array}{c}0.431 \\
(0.65)\end{array}$ & & & & & & & & & 8.76 \\
\hline$(4)$ & $\begin{array}{l}0.057 \\
(0.33)\end{array}$ & $\begin{array}{l}\mathbf{1 . 4 3 4} \\
(2.71)\end{array}$ & & $\begin{array}{c}0.033 \\
(0.55)\end{array}$ & $\begin{array}{l}-0.053 \\
(-0.79)\end{array}$ & $\begin{array}{l}-0.027 \\
(-0.28)\end{array}$ & $\begin{array}{l}0.029 \\
(1.36)\end{array}$ & $\begin{array}{c}\mathbf{0 . 0 3 0} \\
(3.09)\end{array}$ & $\begin{array}{l}0.008 \\
(0.85)\end{array}$ & $\begin{array}{l}0.032 \\
(0.26)\end{array}$ & $\begin{array}{c}\mathbf{- 0 . 1 1 4} \\
(-9.65)\end{array}$ & 20.43 \\
\hline$(5)$ & $\begin{array}{l}0.422 \\
(1.06)\end{array}$ & & $\begin{array}{c}0.428 \\
(0.64)\end{array}$ & $\begin{array}{c}0.082 \\
(1.24)\end{array}$ & $\begin{array}{l}-0.090 \\
(-1.06)\end{array}$ & $\begin{array}{l}0.065 \\
(0.55)\end{array}$ & $\begin{array}{c}0.017 \\
(0.74)\end{array}$ & $\begin{array}{c}\mathbf{0 . 0 7 6} \\
(3.02)\end{array}$ & $\begin{array}{l}-0.019 \\
(-0.80)\end{array}$ & $\begin{array}{l}0.055 \\
(0.65)\end{array}$ & $\begin{array}{c}\mathbf{- 0 . 0 9 7} \\
(-7.69)\end{array}$ & 21.14 \\
\hline (6) & $\begin{array}{l}0.021 \\
(0.23) \\
\end{array}$ & $\begin{array}{l}\mathbf{1 . 0 3 4} \\
(2.14) \\
\end{array}$ & $\begin{array}{r}0.073 \\
(0.12) \\
\end{array}$ & $\begin{array}{r}0.012 \\
(0.05) \\
\end{array}$ & $\begin{array}{l}-0.098 \\
(-0.84) \\
\end{array}$ & $\begin{array}{l}0.031 \\
(0.21) \\
\end{array}$ & $\begin{array}{r}0.019 \\
(0.96) \\
\end{array}$ & $\begin{array}{r}\mathbf{0 . 0 5 4} \\
(3.38) \\
\end{array}$ & $\begin{array}{l}0.014 \\
(1.27) \\
\end{array}$ & $\begin{array}{l}0.027 \\
(0.36) \\
\end{array}$ & $\begin{array}{r}\mathbf{- 0 . 0 7 6} \\
(-6.27) \\
\end{array}$ & 22.39 \\
\hline
\end{tabular}


Table A.7: Robustness Check: Predicting Aggregate Bond Market Returns and Volatility Using Aggregate Systematic Risk

This table replicates Table 9 by replacing the value-weighted aggregate systematic risk (SR) with the equal-, and rating-weighted average of systematic risk of individual bonds. The table presents results from the monthly predictive regressions with the value-weighted corporate bond market index $\left(\mathrm{VW}^{\text {bond }}\right.$ ) in Panel A and aggregate monthly bond market variance $\left(\mathrm{MKT}^{V o l}\right)$ in Panel B. The sample period is from January 1997 to June 2019. $t$-statistics are reported in parentheses and ${ }^{*},{ }^{* *}$, and ${ }^{* * *}$ indicate the significance at the $10 \%, 5 \%$, and $1 \%$ level, respectively.

\begin{tabular}{|c|c|c|c|c|c|c|c|c|c|c|c|c|}
\hline \multirow[t]{2}{*}{ Forecasting horizon } & $t=1$ & $t=2$ & $t=3$ & $t=4$ & $t=5$ & $t=6$ & $t=7$ & $t=8$ & $t=9$ & $t=10$ & $t=11$ & $t=12$ \\
\hline & \multicolumn{12}{|c|}{ Equal-weighted SR } \\
\hline Intercept & $\begin{array}{c}3.24 \\
(0.46)\end{array}$ & $\begin{array}{c}-6.24 \\
(-0.76)\end{array}$ & $\begin{array}{c}0.31 \\
(0.04)\end{array}$ & $\begin{array}{c}8.82 \\
(1.00)\end{array}$ & $\begin{array}{l}10.15 \\
(1.20)\end{array}$ & $\begin{array}{c}6.96 \\
(0.72)\end{array}$ & $\begin{array}{c}4.43 \\
(0.53)\end{array}$ & $\begin{array}{l}14.79^{*} \\
(1.77)\end{array}$ & $\begin{array}{c}17.24^{* *} \\
(2.20)\end{array}$ & $\begin{array}{l}15.26^{*} \\
(1.83)\end{array}$ & $\begin{array}{l}11.66 \\
(1.61)\end{array}$ & $\begin{array}{l}11.70^{*} \\
(1.70)\end{array}$ \\
\hline $\begin{array}{c}\text { SR } \\
\text { Controls }\end{array}$ & $\begin{array}{c}1.47^{* * *} \\
(2.96) \\
\mathrm{Y}\end{array}$ & $\begin{array}{c}1.65^{* * *} \\
(3.10) \\
Y\end{array}$ & $\begin{array}{c}1.56^{* * *} \\
(3.03) \\
Y\end{array}$ & $\begin{array}{c}1.25^{* *} \\
(2.32) \\
\mathrm{Y}\end{array}$ & $\begin{array}{c}1.09^{* *} \\
(2.25) \\
\mathrm{Y}\end{array}$ & $\begin{array}{c}1.07^{* *} \\
(2.10) \\
\mathrm{Y}\end{array}$ & $\begin{array}{c}0.95^{*} \\
(1.86) \\
\mathrm{Y}\end{array}$ & $\begin{array}{c}1.05^{* *} \\
(2.25) \\
Y\end{array}$ & $\begin{array}{c}0.78 \\
(1.58) \\
Y\end{array}$ & $\begin{array}{c}0.78 \\
(1.52) \\
Y\end{array}$ & $\begin{array}{c}0.76 \\
(1.61) \\
\mathrm{Y}\end{array}$ & $\begin{array}{c}0.78 \\
(1.56) \\
Y\end{array}$ \\
\hline Adj. $R^{2}(\%)$ & 22.82 & 21.49 & 15.84 & 12.65 & 15.63 & 16.94 & 12.98 & 10.09 & 8.87 & 9.06 & 6.22 & 2.52 \\
\hline
\end{tabular}

\begin{tabular}{|c|c|c|c|c|c|c|c|c|c|c|c|c|}
\hline \multirow[b]{2}{*}{ Intercept } & \multicolumn{12}{|c|}{ Rating-weighted SR } \\
\hline & $\begin{array}{c}3.32 \\
(0.47)\end{array}$ & $\begin{array}{c}-6.37 \\
(-0.76)\end{array}$ & $\begin{array}{c}0.40 \\
(0.05)\end{array}$ & $\begin{array}{c}9.07 \\
(1.03)\end{array}$ & $\begin{array}{l}10.30 \\
(1.22)\end{array}$ & $\begin{array}{c}7.09 \\
(0.73)\end{array}$ & $\begin{array}{c}4.46 \\
(0.53)\end{array}$ & $\begin{array}{c}14.86^{*} \\
(1.78)\end{array}$ & $\begin{array}{c}17.27^{* *} \\
(2.20)\end{array}$ & $\begin{array}{l}15.37^{*} \\
(1.84)\end{array}$ & $\begin{array}{l}11.84 \\
(1.63)\end{array}$ & $\begin{array}{l}12.00^{*} \\
(1.74)\end{array}$ \\
\hline SR & $\begin{array}{c}2.37 * * * \\
(2.87)\end{array}$ & $\begin{array}{c}2.51^{* * *} \\
(2.81)\end{array}$ & $\begin{array}{c}2.57 * * * \\
(2.96)\end{array}$ & $\begin{array}{c}2.22^{* *} \\
(2.58)\end{array}$ & $\begin{array}{l}1.88^{* *} \\
(2.40)\end{array}$ & $\begin{array}{l}1.82 * * \\
(2.20)\end{array}$ & $\begin{array}{l}1.55^{*} \\
(1.89)\end{array}$ & $\begin{array}{l}1.75 * * \\
(2.28)\end{array}$ & $\begin{array}{c}1.30 \\
(1.61)\end{array}$ & $\begin{array}{l}1.37^{*} \\
(1.67)\end{array}$ & $\begin{array}{c}1.20 \\
(1.34)\end{array}$ & $\begin{array}{c}1.18 \\
(1.38)\end{array}$ \\
\hline Controls & $\mathrm{Y}$ & $\mathrm{Y}$ & $\mathrm{Y}$ & $\mathrm{Y}$ & $\mathrm{Y}$ & $\mathrm{Y}$ & $\mathrm{Y}$ & Y & $\mathrm{Y}$ & $\mathrm{Y}$ & $\mathrm{Y}$ & $\mathrm{Y}$ \\
\hline Adj. $R^{2}(\%)$ & 22.76 & 21.08 & 15.93 & 13.03 & 15.81 & 17.07 & 13.00 & 10.15 & 8.90 & 9.19 & 6.40 & 2.78 \\
\hline
\end{tabular}

\begin{tabular}{|c|c|c|c|c|c|c|c|c|c|c|c|c|}
\hline \multirow[t]{2}{*}{ Forecasting horizon } & $t=1$ & $t=2$ & $t=3$ & $t=4$ & $t=5$ & $t=6$ & $t=7$ & $t=8$ & $t=9$ & $t=10$ & $t=11$ & $t=12$ \\
\hline & \multicolumn{12}{|c|}{ Equal-weighted SR } \\
\hline Intercept & $\begin{array}{c}9.76 \\
(1.25)\end{array}$ & $\begin{array}{l}13.92 \\
(1.26)\end{array}$ & $\begin{array}{c}20.02^{*} \\
(1.77)\end{array}$ & $\begin{array}{c}18.55^{*} \\
(1.83)\end{array}$ & $\begin{array}{c}20.36^{* *} \\
(2.25)\end{array}$ & $\begin{array}{c}29.67^{* * *} \\
(2.69)\end{array}$ & $\begin{array}{c}29.50^{* *} \\
(2.44)\end{array}$ & $\begin{array}{c}23.77^{* *} \\
(2.07)\end{array}$ & $\begin{array}{c}18.54^{* *} \\
(2.15)\end{array}$ & $\begin{array}{c}20.65^{* * *} \\
(2.63)\end{array}$ & $\begin{array}{c}21.82^{* *} \\
(2.50)\end{array}$ & $\begin{array}{c}20.18^{* *} \\
(2.19)\end{array}$ \\
\hline Controls & $\begin{array}{c}1.61^{* * *} \\
(2.63) \\
\mathrm{Y}\end{array}$ & $\begin{array}{c}1.42^{* *} \\
(2.16) \\
Y\end{array}$ & $\begin{array}{c}1.31^{* *} \\
(2.00) \\
\mathrm{Y}\end{array}$ & $\begin{array}{c}1.40^{* *} \\
(2.26) \\
\mathrm{Y}\end{array}$ & $\begin{array}{c}1.25^{*} \\
(1.88) \\
\mathrm{Y}\end{array}$ & $\begin{array}{c}1.26^{*} \\
(1.84) \\
Y\end{array}$ & $\begin{array}{c}1.14^{*} \\
(1.66) \\
Y\end{array}$ & $\begin{array}{c}1.05 \\
(1.53) \\
\mathrm{Y}\end{array}$ & $\begin{array}{c}1.14^{*} \\
(1.70) \\
Y\end{array}$ & $\begin{array}{c}1.12 \\
(1.65) \\
Y\end{array}$ & $\begin{array}{c}1.18^{*} \\
(1.73) \\
\mathrm{Y}\end{array}$ & $\begin{array}{c}1.09 \\
(1.55) \\
\mathrm{Y}\end{array}$ \\
\hline \multirow[t]{2}{*}{ Adj. $R^{2}(\%)$} & 34.63 & 24.24 & 22.18 & 21.72 & 15.39 & 12.70 & 12.82 & 10.61 & 10.49 & 6.70 & 7.09 & 6.33 \\
\hline & \multicolumn{12}{|c|}{ Rating-weighted SR } \\
\hline Intercept & $\begin{array}{l}10.16 \\
(1.30)\end{array}$ & $\begin{array}{l}14.39 \\
(1.29)\end{array}$ & $\begin{array}{c}20.45^{*} \\
(1.80)\end{array}$ & $\begin{array}{l}18.84^{*} \\
(1.86)\end{array}$ & $\begin{array}{c}20.56^{* *} \\
(2.27)\end{array}$ & $\begin{array}{c}29.86^{* * *} \\
(2.71)\end{array}$ & $\begin{array}{c}29.52^{* *} \\
(2.44)\end{array}$ & $\begin{array}{c}23.70^{* *} \\
(2.06)\end{array}$ & $\begin{array}{c}18.55^{* *} \\
(2.16)\end{array}$ & $\begin{array}{c}20.50^{* *} \\
(2.60)\end{array}$ & $\begin{array}{c}21.68^{* *} \\
(2.47)\end{array}$ & $\begin{array}{c}20.20^{* *} \\
(2.18)\end{array}$ \\
\hline Controls & $\begin{array}{c}2.85^{* * *} \\
(2.89) \\
\mathrm{Y}\end{array}$ & $\begin{array}{c}2.67^{* *} \\
(2.55) \\
Y\end{array}$ & $\begin{array}{c}2.48^{* *} \\
(2.38) \\
\mathrm{Y}\end{array}$ & $\begin{array}{c}2.50^{* *} \\
(2.53) \\
Y\end{array}$ & $\begin{array}{c}2.18^{* *} \\
(2.00) \\
\mathrm{Y}\end{array}$ & $\begin{array}{c}2.19^{* *} \\
(1.98) \\
\mathrm{Y}\end{array}$ & $\begin{array}{c}1.86^{*} \\
(1.66) \\
Y\end{array}$ & $\begin{array}{c}1.63 \\
(1.46) \\
\mathrm{Y}\end{array}$ & $\begin{array}{c}1.86^{*} \\
(1.72) \\
Y\end{array}$ & $\begin{array}{c}1.69 \\
(1.51) \\
Y\end{array}$ & $\begin{array}{c}1.78 \\
(1.58) \\
Y\end{array}$ & $\begin{array}{c}1.73 \\
(1.52) \\
\mathrm{Y}\end{array}$ \\
\hline Adj. $R^{2}(\%)$ & 35.03 & 24.79 & 22.68 & 22.04 & 15.57 & 12.88 & 12.82 & 10.53 & 10.50 & 6.55 & 6.92 & 6.27 \\
\hline
\end{tabular}




\section{Table A.8: Robustness Check: The Intertemporal Risk-Return Tradeoff in the Corporate Bond Market}

This table reports the time-series predictive power of the value-, equal-, and rating-weighted average of total variance $\left(\sigma_{m}^{2}\right)$ of individual bonds in predicting one-month-ahead returns on the value-weighted corporate bond market index $\left(\mathrm{VW}^{\text {bond }}\right)$ and the Merrill Lynch bond index $\left(\mathrm{MRL}^{\text {bond }}\right)$. Panel A reports the univariate regression results. Panel B reports the multivariate regression results after controlling for macroeconomic variables used in Table 1. The sample period is from January 1997 to June 2019. $t$-statistics are reported in the parentheses and ${ }^{*},{ }^{* *}$, and ${ }^{* * *}$ indicate the significance at the $10 \%, 5 \%$, and $1 \%$ level, respectively.

Panel A: Univariate regressions

\begin{tabular}{|c|c|c|c|c|c|c|c|c|}
\hline \multicolumn{3}{|c|}{ Value-weighted } & \multicolumn{3}{|c|}{ Equal-weighted } & \multicolumn{3}{|c|}{ Rating-weighted } \\
\hline Intercept & $\sigma_{m}^{2}$ & Adj. $R^{2}(\%)$ & Intercept & $\sigma_{m}^{2}$ & Adj. $R^{2}(\%)$ & Intercept & $\sigma_{m}^{2}$ & Adj. $R^{2}(\%)$ \\
\hline \multicolumn{3}{|c|}{ Dep. Var $=\mathrm{VW}^{\text {bond }}$} & \multicolumn{3}{|c|}{ Dep. Var $=\mathrm{VW}^{\text {bond }}$} & \multicolumn{3}{|c|}{ Dep. Var $=\mathrm{VW}^{\text {bond }}$} \\
\hline $\begin{array}{c}0.03 \\
(0.18) \\
\end{array}$ & $\begin{array}{c}2.00^{* * *} \\
(2.61) \\
\end{array}$ & 7.77 & $\begin{array}{c}0.12 \\
(0.86) \\
\end{array}$ & $\begin{array}{l}1.00^{* *} \\
(2.51)\end{array}$ & 7.37 & $\begin{array}{c}0.12 \\
(0.88)\end{array}$ & $\begin{array}{l}1.53^{* *} \\
(2.28)\end{array}$ & 7.37 \\
\hline \multicolumn{3}{|c|}{ Dep. $\operatorname{Var}=\mathrm{MRL}^{\text {bond }}$} & \multicolumn{3}{|c|}{ Dep. $\operatorname{Var}=\mathrm{MRL}^{\text {bond }}$} & \multicolumn{3}{|c|}{ Dep. $\operatorname{Var}=\mathrm{MRL}^{\text {bond }}$} \\
\hline $\begin{array}{c}0.02 \\
(0.11)\end{array}$ & $\begin{array}{c}1.63^{* *} \\
(2.48)\end{array}$ & 4.38 & $\begin{array}{c}0.09 \\
(0.59)\end{array}$ & $\begin{array}{c}0.83^{* *} \\
(2.48)\end{array}$ & 4.29 & $\begin{array}{c}0.08 \\
(0.56)\end{array}$ & $\begin{array}{l}1.30^{* *} \\
(2.28)\end{array}$ & 4.29 \\
\hline
\end{tabular}

Panel B: Multivariate regressions

\begin{tabular}{|c|c|c|c|c|c|c|c|}
\hline Intercept & $\sigma_{m}^{2}$ & $\mathrm{EP}$ & DP & $\mathrm{BM}$ & DEF & TERM & Adj. $R^{2}(\%)$ \\
\hline \multicolumn{8}{|c|}{ Value-weighted } \\
\hline \multicolumn{8}{|c|}{ Dep. $\operatorname{var}=\mathrm{VW}_{t+1}^{\text {bond }}$} \\
\hline $\begin{array}{c}6.47 \\
(1.24)\end{array}$ & $\begin{array}{c}1.34^{* * *} \\
(4.68)\end{array}$ & $\begin{array}{l}-0.32 \\
(-0.98)\end{array}$ & $\begin{array}{l}1.85^{*} \\
(1.81)\end{array}$ & $\begin{array}{c}-0.43 \\
(-0.22)\end{array}$ & $\begin{array}{c}0.18^{* * *} \\
(2.97)\end{array}$ & $\begin{array}{c}0.16^{* * *} \\
(2.72)\end{array}$ & 23.40 \\
\hline \multicolumn{8}{|c|}{ Dep. var $=\mathrm{MRL}_{t+1}^{\text {bond }}$} \\
\hline $\begin{array}{c}4.06 \\
(0.75)\end{array}$ & $\begin{array}{c}1.13^{* * *} \\
(3.30) \\
\end{array}$ & $\begin{array}{l}-0.22 \\
(-0.61)\end{array}$ & $\begin{array}{c}1.21 \\
(1.18)\end{array}$ & $\begin{array}{c}0.17 \\
(0.07)\end{array}$ & $\begin{array}{c}0.18^{* *} \\
(2.18) \\
\end{array}$ & $\begin{array}{c}0.10^{* *} \\
(2.38) \\
\end{array}$ & 11.42 \\
\hline
\end{tabular}

Equal-weighted

\begin{tabular}{|c|c|c|c|c|c|c|c|}
\hline \multicolumn{8}{|c|}{ Dep. $\operatorname{var}=\mathrm{VW}_{t+1}^{\text {bond }}$} \\
\hline $\begin{array}{c}5.52 \\
(1.01)\end{array}$ & $\begin{array}{c}0.63^{* * *} \\
(4.63)\end{array}$ & $\begin{array}{l}-0.38 \\
(-1.17)\end{array}$ & $\begin{array}{c}1.66 \\
(1.55)\end{array}$ & $\begin{array}{c}-0.15 \\
(-0.07)\end{array}$ & $\begin{array}{c}0.18^{* * *} \\
(2.99)\end{array}$ & $\begin{array}{c}0.16^{* * *} \\
(2.71)\end{array}$ & 22.99 \\
\hline \multicolumn{8}{|c|}{ Dep. $\operatorname{var}=\mathrm{MRL}_{t+1}^{\text {bond }}$} \\
\hline $\begin{array}{c}3.33 \\
(0.61)\end{array}$ & $\begin{array}{c}0.55^{* * *} \\
(3.50)\end{array}$ & $\begin{array}{c}-0.27 \\
(-0.77)\end{array}$ & $\begin{array}{c}1.06 \\
(1.02)\end{array}$ & $\begin{array}{c}0.35 \\
(0.14)\end{array}$ & $\begin{array}{c}0.18^{* *} \\
(2.19)\end{array}$ & $\begin{array}{c}0.10^{* *} \\
(2.37)\end{array}$ & 11.27 \\
\hline \multicolumn{8}{|c|}{ Rating-weighted } \\
\hline \multicolumn{8}{|c|}{ Dep. var $=\mathrm{VW}_{t+1}^{\text {bond }}$} \\
\hline $\begin{array}{c}5.20 \\
(0.90)\end{array}$ & $\begin{array}{c}1.00^{* * * *} \\
(4.48)\end{array}$ & $\begin{array}{c}-0.46 \\
(-1.36)\end{array}$ & $\begin{array}{c}1.64 \\
(1.46)\end{array}$ & $\begin{array}{c}-0.04 \\
(-0.02)\end{array}$ & $\begin{array}{c}0.18^{* * *} \\
(2.97)\end{array}$ & $\begin{array}{c}0.16^{* * *} \\
(2.70)\end{array}$ & 22.82 \\
\hline \multicolumn{8}{|c|}{ Dep. $\operatorname{var}=\mathrm{MRL}_{t+1}^{\text {bond }}$} \\
\hline $\begin{array}{c}3.14 \\
(0.57)\end{array}$ & $\begin{array}{c}0.91^{* * *} \\
(3.55)\end{array}$ & $\begin{array}{c}-0.32 \\
(-0.96)\end{array}$ & $\begin{array}{c}1.06 \\
(1.01)\end{array}$ & $\begin{array}{c}0.37 \\
(0.15)\end{array}$ & $\begin{array}{c}0.18^{* *} \\
(2.18)\end{array}$ & $\begin{array}{c}0.10^{* *} \\
(2.34)\end{array}$ & 11.31 \\
\hline
\end{tabular}

